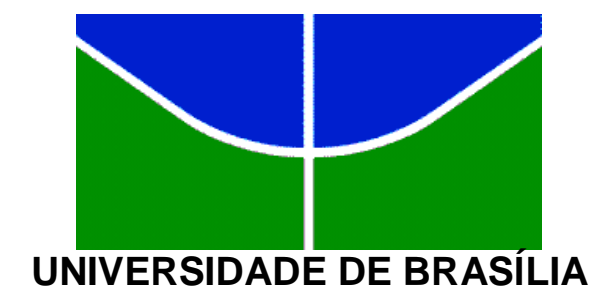

Centro de Excelência em Turismo

Pós-graduação Lato Sensu

Curso de Especialização em Gestão de Negócios em Turismo

\title{
ESTUDO DE VIABILIDADE PARA IMPLANTAÇÃO DE UMA AGÊNCIA DE EVENTOS
}

\section{Ana Paula Carvalho Lopes}


UNIVERSIDADE DE BRASÍLIA Centro de Excelência em Turismo

Pós-graduação Lato Sensu

Curso de Especialização em Gestão de Negócios em Turismo

\section{ESTUDO DE VIABILIDADE PARA IMPLANTAÇÃO DE UMA AGÊNCIA DE EVENTOS}

\section{Ana Paula Carvalho Lopes}

Prof $^{\mathrm{a}}$ Mestre Shirley Pontes, orientadora.

Monografia apresentada ao Centro de Excelência em Turismo - CET, da Universidade de Brasília - UnB, como requisito parcial à obtenção do grau de Especialista em Gestão de Negócios em Turismo. 
UNIVERSIDADE DE BRASÍLIA

Centro de Excelência em Turismo

Pós-graduação Lato Sensu

Curso de Especialização em Gestão de Negócios em Turismo

Ana Paula Carvalho Lopes

Aprovado por:

Professora orientadora: Shirley Pontes, Mestre.

Professor: Domingos Spezia, Mestre.

Professor : Walter Ribeiro, Mestre.

Monografia apresentada ao Centro de Excelência em Turismo - CET, da Universidade de Brasília - UnB, como requisito parcial à obtenção do grau de Especialista em Gestão de Negócios em Turismo.

Brasília, 31 de Maio de 2007 


\section{DEDICATÓRIA}

A todos aqueles que me acolheram em Brasília de braços abertos neste 1 ano e 4 meses, a todos que tive o prazer de conviver neste periodo, principalmente os amigos da Patota, as amigas das Céllas, do MDS, do Hotel Meliá, aos muitos clientes, turma do CET, aos da familia que moram em Brasília, enfim a todos os que conheci e tive muitas alegrias, nesse pedacinho de vida na Capital.

Dedico a todos voces! 


\section{AGRADECIMENTOS}

A Deus, que esteve sempre ao meu lado em mais essa conquista.

A todos os professores do curso, que colaboraram para minha formação profissional e intelectual, despertanto meu senso crítico e a vontade de aprender a cada dia mais, em especial a minha orientadora Professora Shirley Pontes e ao Professor Domingos Spezia, pela compreensão e o apoio constante.

Aos meus colegas do CET, essa turma de catalisadores, pela troca constante de idéias diferentes, discussões, bagunças, aprendizado e muita alegria.

Aos grandes amigos que fiz no curso: Priscila, Eduardo, Tati, Ana Carol, Paloma, Camila, Pri Grintzos, Rodrigo, Sheila, Kellen e Thadeu, amizade que vai além da sala de aula, presentes especiais que este curso me deu.

Ao Luis e ao Pedro da secretaria, pela disposição e apoio sistemáticos.

A todos os amigos, em especial a Patota e as Cellas, pela amizade verdadeira, carinho, força, companhia e claro pelas constantes baladas e festas no ap, mas principalmente por terem sido um pedaço da minha familia em Brasília.

Ao Tio Gil e a Flor que por vários fins de semana me adotavam como filha, me acolhendo e suprindo todo o carinho familiar.

A minha prima, companheira e grande amiga Myriam, que sempre me apoiou, me ensinou e me entendeu, pelas nossas longas conversas, confiança, amor e carinho. Com ela ao meu lado em Brasíia, tudo se tornava muito mais fácil, e mais uma vez estamos juntas, agora nessa aventura na Itália.

Aos meus pais, Paulo e Márcia, exemplos de caráter, solidariedade, honestidade, profissionalismo e amor incondicional. Que sempre investiram na minha formação, estimulando e incentivando a busca constante de conhecimento e crescimento profissional, são, sem dúvida, os responsáveis por mais essa conquista.

Aos meu irmãos Juliana, Mariana e Rafael, aos meus sobrinhos Gabriela e Enzo, e todos aqueles da família e amigos que mesmo longe estavam perto, dando força e estímulo para continuar sempre.

A todos aqueles dos hotéis, restaurantes, eventos, todos os locais, onde tive a oportunidade de trabalhar ou fazer estágio, que de alguma forma agregou muito conhecimento e me deu bagagem para chegar até aqui. 


\section{RESUMO}

O mercado de eventos no Brasil evoluiu para um negócio bem desenvolvido nas últimas décadas. O setor cresce de maneira bastante acelerada, exigindo cada vez mais métodos de planejamento e organização, espaços bem equipados, profissionais especializados e marketing competitivo e eficiente na disputa por uma fatia do mercado que, segundo dados da Federação Brasileira de Convention \& Visitors Bureaux,movimenta no mundo aproximadamente US\$850 bilhões e no Brasil $R \$ 1,3$ bilhão, gerando 3 milhões de empregos. O presente trabalho teve como principal objetivo realizar um projeto de criação de empresa no segmento de eventos, comprovando a viabilidade e propondo a implantação de uma agência de eventos na cidade de Brasília, que oferecerá um mix de produtos amplo, com qualidade, suprindo a demanda local que existe. A metodologia utilizada neste estudo foi a de pesquisa descritiva quantitativa. A coleta de dados utilizou questionário estruturado, que é composto por perguntas fechadas. Os dados obtidos foram tabulados e analisados segundo estatística descritiva, demonstrando que a implantação de uma nova agência de eventos na capital brasileira é de grande aceitação dos consumidores. Os resultados da pesquisa, juntamente com a análise de outros aspectos, como localização, demanda, fornecedores, concorrência, recursos humanos, equipamentos, e dados financeiros, revelam que 0 empreendimento apresenta viabilidade nos planos mercadológico, técnicoadministrativo e econômico-financeiro, e sua execução é recomendável.

Palavras-chave: empreendedorismo, plano de negócios, turismo de eventos. 


\begin{abstract}
The event trade in Brazil evolved to a great business in the last years. The sector grow-up quickly, demanding a better way of planning and organization, well equipped spaces, specialized professionals and a competitive and efficient marketing to dispute a trade slice, that according to data of the Brazilian Federacy of Convention \& Visitors Bureaux it puts into motion in the world approximately US $\$ 850$ billion and in Brazil $R \$ 1.3$ billion, providing 3 milion jobs. This work had as main purpose to realize a business breeding plan about event area, proving the possibilty and proposing the event company implantation in the Brasilia city, that will offer a big mix of product, with quality, supplying the local demand. The metodology has been used in this study was quantitative descriptive research, through collects of data with field research, using questionary structuralized which is composed only for closed questions. The gotten data had been tabulated and analyzed through diagram, demonstrating that the implantation of a new event company in Brasilia is very acceptable. The research results, with others aspects analyzed, like location, demand, suppliers, competition, human resources, equipment and financial data, reveal viability in marketing plans, administrative technician, financial economic in this enterprise, and your execution is recommendable.
\end{abstract}

Key-words: entrepreneurship area, plan business, tourism of events. 


\section{LISTA DE QUADROS}

QUADRO 1: Memória de Cálculo da Estimativa da Receita.................................56

QUADRO 2: Empresas Competidoras .......................................................62

QUADRO 3: Mix de Produtos e Serviços Oferecidos........................................68

QUADRO 4: Quadro de Recursos Humanos ....................................................69

QUADRO 5: Recursos Móveis, Materiais e Equipamentos................................72

Quadro 6: Investimento Inicial e Depreciações ..............................................74

QUADRO 7: Despesas Fixas ............................................................................75

QUADRO 8: Custos Variáveis / Despesas de Comercialização .........................75

QUADRO 9: Receita Operacional Mensal.....................................................76

QUADRO 10: Demonstração de Resultado ...................................................76

QUADRO 11: Investimento Inicial ..................................................................77

QUADRO 12: Valores e Índices para Análise ......................................................77 


\section{LISTA DE TABELAS}

TABELA 1: Grau de Interesse em uma Nova Agência de Eventos .47

TABELA 2: Freqüência que o Público Contrata uma Agência de Eventos ........48

TABELA 3: Aspectos Analisados para Escolher uma Agência de Eventos.......50

TABELA 4: Meios Utilizados para Encontrar uma Agência de Eventos..............51

TABELA 5: Eventos para o qual se Contrata uma Agência de Eventos.............53

TABELA 6: Valor Gasto ao Contratar uma Agência de Eventos ..........................54 


\section{LISTA DE GRÁFICOS}

GRÁFICO 1: Grau de Interesse em uma Nova Agência de Eventos .48

GRÁFICO 2: Freqüência que o Público Contrata uma Agência de Eventos .......49

GRÁFICO 3: Aspectos Analisados para Escolher uma Agência de Eventos.....50

GRÁFICO 4: Meios Utilizados para Encontrar uma Agência de Eventos...........52

GRÁFICO 5: Eventos para o qual se Contrata uma Agência de Eventos...........54

GRÁFICO 6: Valor Gasto ao Contratar uma Agência de Eventos .........................55 


\section{SUMÁRIO}

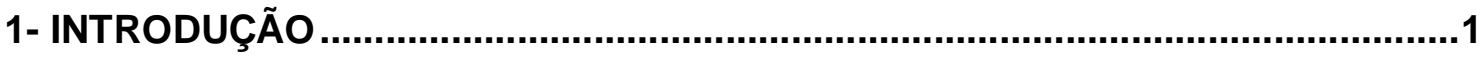

2- REFERENCIAL TEÓRICO ….............................................................................

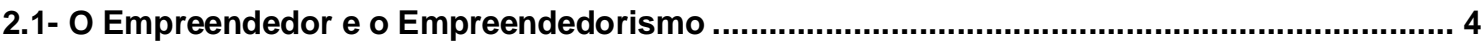

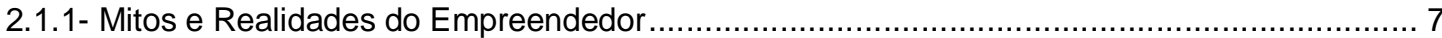

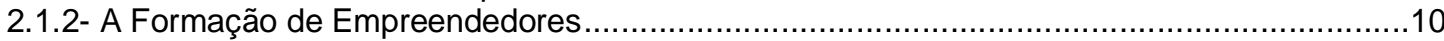

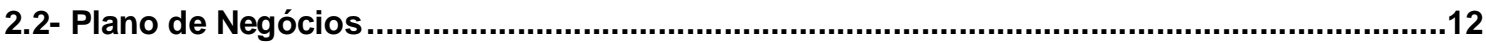

2.2.1- Dez Armadilhas ao Preparar um Plano de Negócios ....................................................15

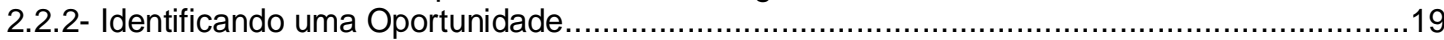

2.3- Marketing

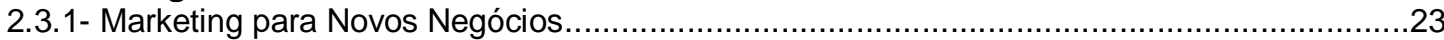

2.3.2- Os 4 P's e os Eventos como Ferramenta do Marketing Promocional...................................24

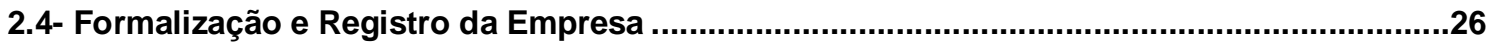

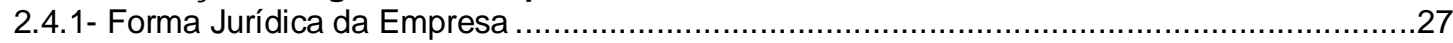

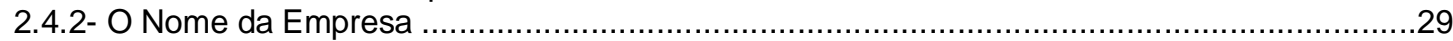

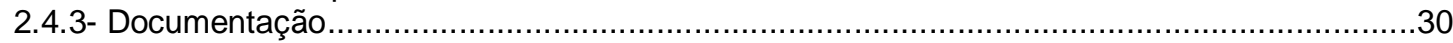

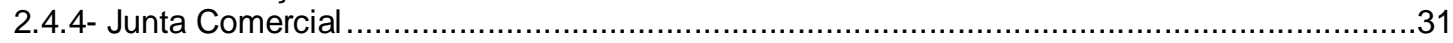

2.4.5- Secretaria da Receita Federal / Secretaria Estadual da Fazenda .......................................31

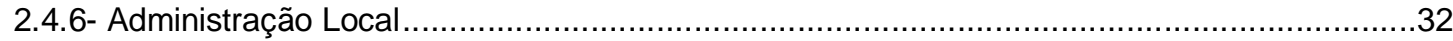

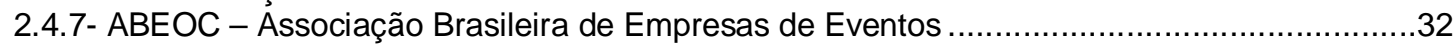

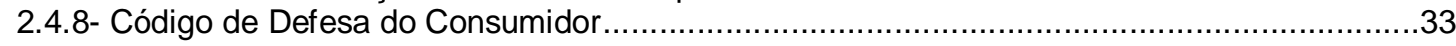

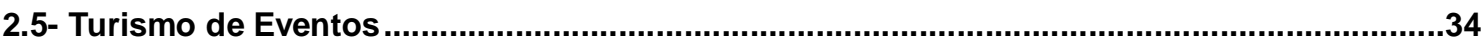

2.5.1- A Importância Econômica do Turismo de Eventos ....................................................................37

2.5.2- Benefícios para as Cidades Receptoras de Eventos .............................................................38

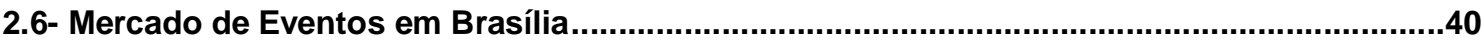

2.6.1- Razões para Realizar um Evento em Brasília....................................................................... 41

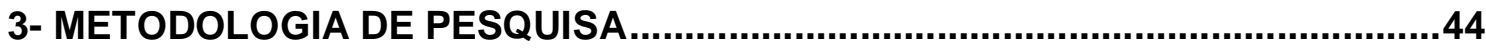

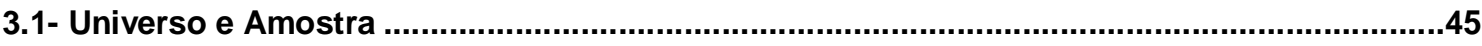

4- PESQUISA DE CAMPO E ANÁLISE DE DADOS.............................................46

4.1- Pesquisa Mercadológica para Embasamento do Plano de Negócios ....................................46

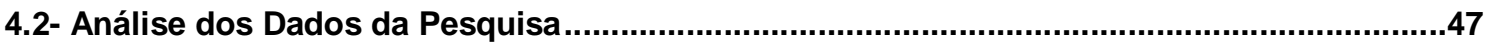

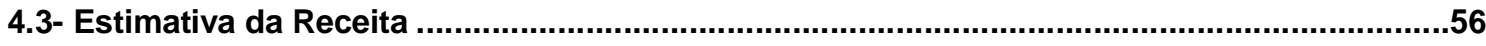

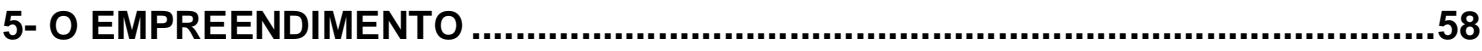

6- VIABILIDADE MERCADOLÓGICA DO EMPREENDIMENTO ............................59

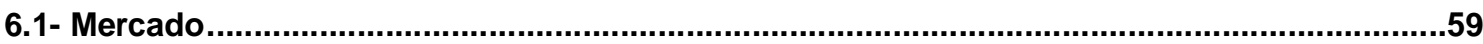

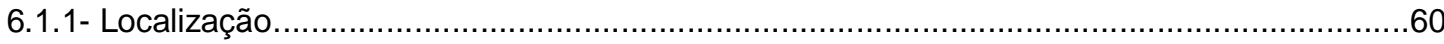

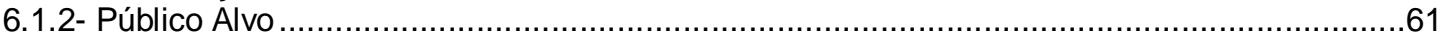

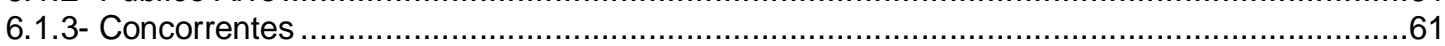


7- VIABILIDADE TÉCNICO-ADMINISTRATIVA....................................................67

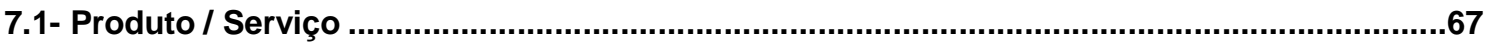

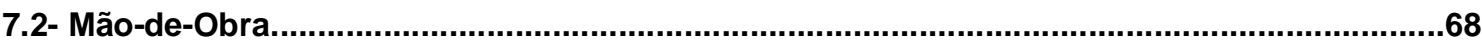

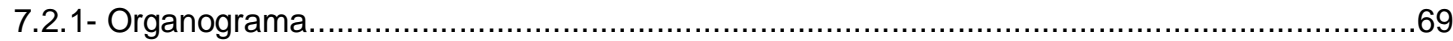

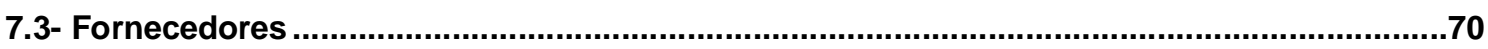

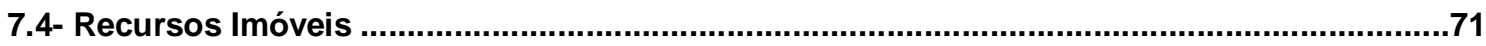

7.5- Recursos Móveis, Materiais, Equipamentos e Utensílios .................................................71

8- VIABILIDADE ECONÔMICA-FINANCEIRA ......................................................73

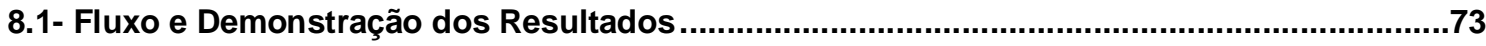

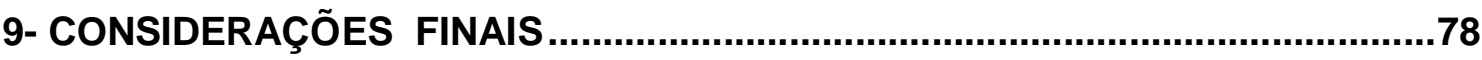

10- REFERÊNCIAS BIBLIOGRÁFICAS........................................................81

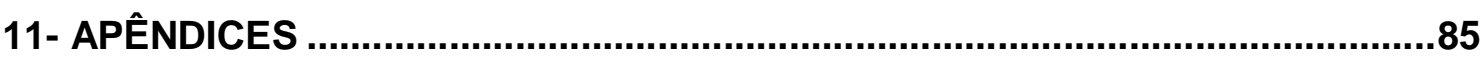

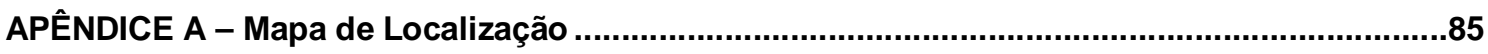

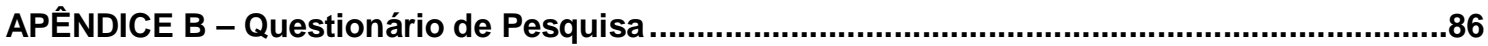




\section{1- INTRODUÇÃO}

Empreender faz parte da natureza humana. Todas as pessoas são empreendedoras, umas mais que as outras, com capacidade de imaginar, de resolver problemas, estar atento a oportunidades, entusiasmar-se com idéias e sonhos, depositar grande confiança em si mesmo, agir de forma criativa e realizadora no meio em que vive, em busca de crescimento pessoal e coletivo.

Normalmente, tratando-se do campo profissional, a primeira idéia que surge ao interessado em criar uma empresa é escolher o ramo de negócios pelo qual sinta afinidade e logo procurar local para estabelecer-se e começar a operar. No entanto, essa não é a maneira utilizada pelos empreendedores bem-sucedidos que, antes de tudo, analisam as várias oportunidades por eles descobertas, buscando as alternativas mais rentáveis, e iniciando assim um Plano de Negócios para comprovar as viabilidades do empreendimento escolhido.

Quanto à oportunidade identificada, é preciso saber se realmente existe uma oportunidade de negócio ou apenas uma idéia na cabeça. No segmento de eventos, esse procedimento não deve ser diferente, pois se trata de um dos segmentos que mais cresce no país e desenvolve relações comerciais tão complexas como outras áreas.

A problematica que originou este estudo foi perceber que as empresas de eventos ganham cada vez mais importância como negócio para empreendedores criativos. Mas são também um negócio para profissionais conscientes das dificuldades que este setor apresenta, capacitados para preveni-las e enfrentá-las. Por ser um mercado fácil de entrar, muitas pessoas sentem-se atraídas em ter o seu próprio negócio, que a princípio, parece ser simples. Gostar de pessoas, saber regras de etiqueta, protocolo de organizaçao de eventos e ter algumas economias, e montar o seu próprio empreendimento, mas não é suficiente para manter esse negócio a longo prazo e, exatamente por isso, muitas empresas não alcançam o sucesso desejado.

Em pesquisa de 2002, o Sebrae-SP constatou que no Brasil 31\% das empresas do gênero que são abertas fracassam no primeiro ano de operação, e $60 \%$ não conseguem chegar a 5 anos de vida. 
Normalmente essas empresas apresentam sinais de que foram deficientes principalmente em duas questões fundamentais: planejamento prévio ou estruturação do negócio, e na sua gestão. Sendo assim, muitos candidatos a empresários ficam pelo caminho, perdem suas economias, muitas vezes seu patrimônio e se frustam pessoal e profissionalmente.

O profissional de eventos, entre outras qualidades, deve ser seguro, gerando confiança para o cliente e para os funcionários; disciplinado, respeitando prazos, verbas, reuniões; ter flexibilidade, aceitando sugestões, adequando propostas, mudando etapas de trabalho; ter raciocínio rápido, entendendo a capacidade, os anseios e as expectativas dos clientes e funcionários; ter preparo físico, disposição e saúde; ser realista, percebendo os limites, as opções e saber usá-las sabiamente; ter paciência infinita, exercendo o autocontrole e a serenidade. (BRITTO \& FONTES, 2002).

Acreditando que se o candidato a empreendedor reunir não só as características básicas para abrir o seu negócio, mas também se dispor a realizar um planejamento cuidadoso, com a realizaçao de um minucioso Plano de Negocios, justifica-se a realizaçao deste estudo, para demonstrar que este é uma importante ferramenta que permite prever os resultados das viabilidades do empreendimento que se quer montar, aumentando-se as chances de sucesso e minimizando-se os riscos.

Sendo assim, o objetivo geral deste estudo é analisar a viabilidade de Implantação de uma agência de eventos - uma empresa de prestação de serviço no segmento de turismo e hotelaria na cidade de Brasília-DF.

Os objetivos específicos do estudo são:

- Fazer uma pesquisa quantitativa no mercado e verificar a viabilidade mercadológica do empreendimento;

- Identificar o grau de interesse do público alvo, em utilizar os serviços e produtos de uma nova agência de eventos em Brasília;

- Identificar os produtos e serviços de maior consumo e preferência em uma agência de eventos;

- Fazer um estudo e verificar a viabilidade técnica-administrativa do empreendimento; e econômica-financeira do empreendimento; 
A metodologia utilizada para este estudo foi inicialmente a pesquisa exploratória para levantamento bibliográfico relativo à atividade estudada, em um segundo momento utilizou-se a pesquisa descritiva quantitativa para dimensionar o mercado da atividade. A coleta de dados foi realizada por questionário estruturado com perguntas fechadas, aplicado através de entrevista pessoal, com uma amostra representativa intencional ou por julgamento, composta por 80 pessoas representantes do público alvo, tendo como unidade amostral a cidade de Brasília.

O presente estudo foi estruturado em capítulos, sendo o segundo capítulo o referencial teóorico, onde tratou-se de assuntos como empreendedorismo e o segmento de eventos no Brasil; no terceiro capitulo conceituou-se o empreendimento a ser criado; no quarto, quinto e sexto capitulos, estudou-se as viabilidades do projeto, sendo elas mercadológica, técnico-administrativa e econômica-financeira respectivamente. O capitulo sete foi dedicado ao parecer do estudo das viabilidades, apresentando os resultados gerais.

Para encerrar este trabalho, as considerações finais fazem uma reflexão sobre a importância da realizaçao de um plano de negocios eficiente, e as oportunidades que o mercado de eventos apresenta hoje para o empreendedor que deseja adentra-lo.

Destaca-se ainda, que a escolha do presente objeto de estudo foi resultado de um projeto pessoal e profissional conciliando os conteúdos aprendidos durante o curso de graduação em Turismo e Hotelaria e de pós-graduação em Gestão de Negócios em Turismo, os estágios realizados, as vivências em sala e as experiências profissionais, e coincidiu com a idéia da implantação de uma agência de eventos em Brasília. 


\section{2- REFERENCIAL TEÓRICO}

No presente trabalho buscou-se examinar discussões e referências teóricas, para uma melhor compreensão do Plano de Negócios em questão. Com essa finalidade, identificou-se diversos temas relacionados ao processo de formulação de um Plano de Negócios que permitisse uma adequada análise das viabilidades da empresa a ser criada.

Optou-se por temas como empreendedorismo; perfil do empreendedor, seus mitos e realidades; a formação de empreendedores dentro das instituições de ensino; Plano de Negócios, como elaborá-lo e suas principais armadilhas; como identificar as oportunidades de negócios; marketing, os quatro Ps relacionados ao marketing promocional; todo o processo de formalização e registro para abertura de uma empresa; o que é turismo de eventos, qual a sua importância econômica e os benefícios que ele traz às localidades que sediam os eventos e também um panorama geral do mercado de eventos em Brasília.

\section{1- O Empreendedor e o Empreendedorismo}

Os dias de hoje mostram uma verdadeira revolução, sobretudo no mundo dos negócios. A disseminação das tecnologias da informação acelera a velocidade com que se efetuam os negócios, abrindo grandes oportunidades para os empreendedores. Enquanto no passado os jovens buscavam um emprego, hoje, cada vez mais eles buscam exercer a sua iniciativa e ter seu próprio negócio, aproveitando as oportunidades que aparecem a todo momento, em um mundo globalizado.

Os tipos de trabalho bem remunerados do futuro exigirão capacidade de adaptação a novos ambientes e novas situações, mobilidade entre países e disposição para o aprendizado contínuo. A iniciativa, a criatividade e a capacidade empreendedora serão cada vez mais características distintivas dos profissionais de sucesso (STEMPFER apud TONELLI, 1997, p. 36). 
Segundo Azevedo (1998), o empreendedor é, sobretudo, aquele indivíduo que tem necessidade e é capaz de realizar coisas novas. Contudo, mais que ser capaz de desenvolver novos projetos, o empreendedor é aquele que assume a responsabilidade de conduzir um negócio próprio, de tal forma que esse empreendimento funcione e alcance sucesso.

Tonelli (1997) conclui que essa visão diferenciada, que passa a ser exigida dos profissionais a partir da globalização e da era do conhecimento leva à exigência de que esses novos profissionais possuam características empreendedoras. Ou mesmo, que sejam empreendedores em sua profissão.

O mercado, por sua vez, também pede inovação. Os consumidores estão cada vez mais exigentes, querendo produtos e serviços novos, que devem suprir as necessidades de qualidade, variedade, preço e assistência técnica. E neste caso o empreendedor é o responsável pelo sucesso desses fatores.

"Há muitas oportunidades diferentes de empreendimentos sendo identificadas, e o papel do empreendedor é transformar uma oportunidade em um negócio" (SALIM, 2001, p. 41).

Para essa transformação ser alcançada com êxito, é necessário que o profissional tenha um perfil de empreendedor, seja arrojado e esteja disposto a trabalhar intensamente, estando presente em todos os passos da empresa. Deve ser um líder, porém, não autoritário, estabelecendo uma boa relação com todos os funcionários da empresa. Deve ter persistência em suas ações, enfrentando os obstáculos e os problemas com muito "jogo de cintura", capacidade de construir as soluções, visando os objetivos do empreendimento.

O empreendedor deve ter uma visão global da organização e ser altamente organizado. Ele assume riscos sem se sentir inseguro, pois deve ter senso de oportunidade e não deixar que ela passe desapercebida. Um bom empreendedor deve estar sempre atualizado e, acima de tudo, ser um grande inovador.

A Inovação é a capacidade de criação de novos produtos e serviços, seja por novas formas de apresentação, seja utilizando um produto ou um serviço já existente. Também pode ser uma nova maneira de fabricar algo ou de prestar um serviço que represente ganhos de alguma espécie. (SALIM, 2001, p. 42). 
A falta deste perfil pode causar 0 insucesso de muitos empreendimentos, tendo como principais motivos de fechamento da empresa: a escassez de recursos financeiros, a instabilidade econômica, o mercado limitado, concorrência, problemas pessoais, planos econômicos, localização, inflação, elevados encargos financeiros, falta de organização e administração, entre outros.

No dicionário de Administração, Lacombe (2004, p.128), define empreendedor como "pessoa que percebe oportunidades de oferecer no mercado novos produtos, serviços ou processos e tem coragem de assumir riscos e habilidades para aproveitar essas oportunidades".

O empreendedor é aquele que busca a mudança, reage a ela e vislumbra uma oportunidade, nem sempre vista pelos demais. È o empreendedor que cria algo novo, diferente, inovando ou transformando valores e conseguindo conviver com as incertezas e riscos ao negócio. (PANTZIER apud DRUCKER ,1986, p. 33).

Oliveira (1995, p. 22), faz uma definição mais ampla, afirmando que:

Empreendedor é todo indivíduo que, estando na qualidade de principal tomador de decisões envolvidas, conseguiu formar um novo negócio ou desenvolver negócios já existentes, elevando substancialmente seu valor patrimonial, várias vezes acima da média esperada das empresas congêneres no mesmo período e no mesmo contexto sócio-políticoeconômico, tendo granjeado com isso alto prestígio perante a maioria das pessoas que conhecem essa empresa ou tem relacionamentos com ele.

Como se vê, o empreendedor é um indivíduo com competência empreendedora, isto é, o indivíduo que identifica as oportunidades, articula o conhecimento para gerar habilidades e atitudes empreendedoras.

A diferença de um empreendedor e um empresário é que o primeiro é o fundador de uma empresa, ou então, o que amplia os negócios de uma já existente e de sua propriedade a partir de visões de oportunidades, enquanto o empresário apenas cria, gerencia e mantém rentável uma firma, sem inovar ou fazêla crescer.

Marcondes (1997) defende que, da mesma forma que todos podem aprender a guiar automóveis, todos podem fundar empresa própria, administrar e salvá-las de acidentes de percurso. Tudo é questão de grau, pois enquanto alguns 
poucos são campeões da Fórmula 1 ou Indy, muitos outros apenas são capazes de enfrentar os horrores no trânsito, porém todos dirigem carros.

Assim todos são empreendedores, das grandes figuras das multinacionais, até o dono da padaria da esquina. No entanto, a diferença está na qualidade e no grau de conhecimentos e experiências.

O empreendedor deve ter perfil de líder, saber tomar decisões e ser justo. Existem dois estudos famosos sobre tipos de liderança, de duas universidades americanas, realizados praticamente na mesma época, no ano de 1960, um pela Universidade Estadual de Ohio e outro pela Universidade de Michigan. Ambas apontaram duas linhas básicas de liderança: uma orientada para o desempenho e outra orientada para as pessoas.

\begin{abstract}
Líderes orientados para desempenho estão preocupados em completar as tarefas e os resultados. Empresas que enfatizam apenas este tipo de liderança são aquelas que investem pouco em seus funcionários, estão sempre pensando em cortar custos, em melhorar resultados, mesmo que isso signifique soluções fáceis e rápidas como demissões em massa. Este tipo de administração "açougueiro" acaba gerando muita frustração ao seu redor, e uma imagem antipática junto ao público. Já a empresa que enfatiza muito a liderança para pessoas, preocupa-se em garantir um ambiente de trabalho bom: funcionários satisfeitos, boa relação entre todos, decisões democráticas. Esse modelo é conhecido como administração de clube de campo. (SALIM, 2001, p. 108).
\end{abstract}

No entanto, as empresas de maior sucesso a longo prazo são aquelas que sabem encontrar um equilíbrio entre dois estilos. Por um lado tem uma orientação forte para alcançar resultados, mas mantém uma equipe composta por pessoas felizes e satisfeitas com seu trabalho.

\title{
2.1.1- Mitos e Realidades do Empreendedor
}

Por se tratar de algo novo, ou que recebeu destaque nos últimos anos, muitos são os conceitos de empreendedor, assim como também existem muitos mitos, os quais serão abordados a seguir e todos baseados nos estudos de TIMMONS apud COHEN, 2000:

Mito 1: "Empreendedores nascem feitos", colocando que as pessoas nascem empreendedoras e fica difícil a formação de empreendedores durante a vida. Mas para o autor, "embora empreendedores nasçam com uma certa 
inteligência, vontade de criar e energia, sua formação depende da acumulação de habilidades relevantes, experiência, contatos".

Mito 2: "qualquer um pode começar um negócio", colocando como se fosse algo simples e que não exige nenhuma qualificação. A realidade traz que pode, mas sobreviver e crescer é que são os desafios. "Empreendedores que entendem a diferença entre uma idéia e uma oportunidade e pensam grande têm mais chances de ser bem sucedidos".

Mito 3: "dinheiro é o fator mais importante para montar uma empresa". A realidade apresentada pelo autor argumenta que, "se as outras peças e o talento estão no lugar, o dinheiro virá. É como o pincel e a tinta para um pintor, materiais que, nas mãos certas, produzem maravilhas". Aqui o autor coloca o dinheiro no mesmo nível de outros recursos, sejam eles materiais ou humanos.

Mito 4: "empreendedores não tem chefe e são completamente independentes". Na realidade, o autor afirma que "todo mundo é chefe do empreendedor: seus sócios, investidores, clientes, fornecedores, empregados, família, comunidade. Mas o empreendedor pode escolher as exigências que vão atender, e quando".

Mito 5: "empreendedores devem ser jovens e cheios de energia". $O$ autor expressa que "essas qualidades podem ajudar, mas idade não é barreira. $\mathrm{O}$ critico é possuir o conhecimento relevante, experiência e contatos que facilitam reconhecer e agarrar uma oportunidade". Nesse ponto o autor afirma que não existe uma idade certa para ser empreendedor, pois enquanto o jovem tem energia, podem Ihe faltar conhecimentos e experiências; e para os mais velhos, que possuem experiências e conhecimentos, pode faltar a energia que é exigida do empreendedor.

Mito 6: "empreendedores trabalham mais do que executivos de grandes companhias", o autor diz que "alguns trabalham mais, outros não".

Mito 7: "empreendedores são lobos solitários", e na realidade segundo o autor "os empreendedores mais bem sucedidos são líderes que constroem grandes equipes e ótimos relacionamentos com pares, diretores, investidores, clientes, fornecedores e outros". Aqui é possível analisar que o empreendedor não trabalha sozinho. Como se prega, na administração moderna, é 
através do trabalho em equipe que se alcançam bons resultados, pois existe uma interdependência entre fatores, recursos e pessoas.

Mito 8: "empreendedores são jogadores", mas na realidade: "empreendedores bem sucedidos calculam muito os riscos, eles tentam influenciar o jogo de probabilidades, freqüentemente atraindo outros para dividir os riscos com eles". O autor mostra que os empreendedores são chamados de jogadores porque apostam em seus negócios, mas que têm seus riscos calculados.

Mito 9: "qualquer empreendedor com uma boa idéia pode atrair investimentos de risco". Na realidade o autor apresenta que "nos Estados Unidos, apenas 3 de cada 100 empreendedores com boas idéias conseguem atrair capitais de risco". Verifica-se aqui que não basta ter uma idéia, mas é preciso também convencer alguém de que a idéia é boa e que gerará muito lucro.

Mito 10: "empreendedores querem o show todo só para eles", enquanto a realidade mostra que "privilegiar o próprio ego coloca um teto nas possibilidades de crescimento. Os melhores empreendedores geralmente sabem construir um time, uma organização, uma companhia". O autor não coloca o mito como totalmente errado, mas argumenta que os melhores empreendedores não trabalham sozinhos.

Mito 11: "empreendedores sofrem um estresse tremendo". $\mathrm{Na}$ realidade "sem dúvidas, mas quando não há evidências de que o empreendedor sofra mais estresse do que outros profissionais com muita responsabilidade. A maioria dos empreendedores, ao contrário, acha seu trabalho mais satisfatório".

Esse é um dos mitos que causa grande polêmica, pois o autor não expressa que a vida do empreendedor não é estressante, como toda e qualquer atividade de grande responsabilidade, há estresse. Porém, diz que quando se trata de empreendedor, a ansiedade e a preocupação com os riscos do seu negócio podem ser mais estressantes quando se trabalha com o capital dos outros.

Assim, ao se analisar todos os mitos que envolvem a figura do empreendedor $\mathrm{e}$ as realidades que desmistificam os mitos, entende-se um pouco mais sobre o perfil, as características que um empreendedor deve apresentar e quais devem ser suas atitudes. 


\subsection{2- A Formação de Empreendedores}

Tudo começa como num sonho, como um ideal às vezes distante. Posteriormente vem a decisão de transformar o sonho em realidade. É o momento de confrontar o que se imagina com a realidade. É acreditando nas oportunidades que o empreendedor, munido de sonho e determinação, avança em direção aos seus objetivos. Mas será que ele já dispõe de tudo o que precisa para ser bem sucedido?

É essencial que adquira também o conhecimento do negócio. Conhecimento é tudo o que se constroi ao longo da vida, muita coisa se aprende na prática, e muitas outras através da aquisição de informações, adquiridas pelos estudos e leituras.

Por isso a grande importância da formação profissional das pessoas, momento onde se deve ter muita dedicação, para que os conhecimentos de alguma área específica sejam absorvidos, compreendidos e transformados em uma base sólida que servirá de alicerce para o desenvolvimento e a realização de uma atividade profissional. Se essa base for consistente, rica em informações e conhecimentos, os resultados poderão ser alcançados com sucesso.

A formação ou desenvolvimento de empreendedores também se tornou uma preocupação no sentido de acumular conhecimentos e prepará-los para enfrentar o dia-a-dia e as mais diversas situações que surgirão no decorrer da vida do seu empreendimento.

Passa a ser comum o entendimento de que a aquisição de novos conhecimentos e habilidades constitui-se na melhor forma de sobrevivência tanto pessoal quanto empresarial.

Segundo Bernhoeft (1996), "a escola, depois da família, é a maior fonte de ensino da sociedade". Partindo deste pressuposto, toma-se por base que 0 empreendedorismo pode ser ensinado de maneira formal nas Instituições de Ensino Superior.

Historicamente, houve um crescimento desenfreado de disciplinas e cursos voltados para o empreendedorismo, iniciados aproximadamente em 1968 na Universidade de Harvard. No Brasil, Dolabela (1999) identifica que o primeiro curso 
de empreendedorismo de que se tem notícia surgiu em 1981, na Escola de Administração de Empresas da Fundação Getúlio Vargas, São Paulo.

Este curso teve a iniciativa do professor Ronald Degen e, com o título de "novos negócios", constituía-se de uma disciplina integrante do curso de Especialização em Administração para Graduandos. O mesmo autor também localiza, em 1992, a Universidade Federal de Santa Catarina, com a criação da Escola de Novos Empreendedores (ENE);

A ENE no decorrer do tempo, veio a se constituir em um dos mais significativos projetos universitários de ensino de empreendedorismo no Brasil, com profunda inserção acadêmica e envolvimento tanto com projetos e órgãos internos à UFSC, bem como com outras universidades e organismos internacionais (DOLABELA, 1999, p. 3).

Muitos projetos de empreendedorismo são desenvolvidos por uma série de universidades brasileiras, compondo uma lista que engloba atualmente cerca de 150 (cento e cinqüenta) instituições em todo o País.

Segundo as estimativas de Dolabela (1999, p. 4), "no ano de 1999 cerca de 3000 (três mil) alunos participaram de cursos voltados ao empreendedorismo, sendo envolvidas 200 (duzentas) instituições de educação superior".

Abordando o empreendedorismo fora do ensino superior, Dolabela (1999), dá importância à participação de algumas instituições brasileiras para a difusão do empreendedorismo no Brasil por meio de programas de formação de empreendedores. O autor cita o sistema Brasileiro de Apoio às Micro e Pequenas Empresas - SEBRAE, o Instituto Euvaldo Lodi - IEL, o Conselho Nacional de Desenvolvimento Científico e Tecnológico - CNPQ, o Banco Nacional de Desenvolvimento Econômico e Social - BNDES, a Financiadora de Estudos e projetos - FINEP, Sociedade Softes de Minas Gerais, Fundações de Amparo a Pesquisa, Institutos Estaduais de Pesquisa e Prefeituras.

A formação de qualidade do empreendedor é fundamental, pois ele exerce influência marcante no processo de desenvolvimento econômico, humano e social do país. Com suas realizações, é capaz de ampliar o potencial de uma 
comunidade, gerando empregos, recursos e novos valores. É a sociedade do conhecimento, da informação, da busca permanente de possibilidades e oportunidades.

\section{2- Plano de Negócios}

O mundo empresarial e dos negócios pertence cada vez mais aos empreendedores, isto é, àqueles que identificam as melhores oportunidades e sabem como aproveitá-las. Esses empreendedores são levados a pensar e avaliar bem, sobre os vários fatores que envolvem sua empresa, realizar um planejamento detalhado, antes de iniciar suas atividades.

Nesta nova fase do mundo dos negócios, não se pode nem pensar em abrir ou manter um empreendimento sem antes elaborar um bom Plano de Negócios, pois não há mais espaços para o improviso.

"Plano de Negócios é um documento que contém a caracterização do negócio, sua forma de operar, suas estratégias, seu plano para conquistar uma fatia do mercado e as projeções de despesas, receitas e resultados financeiros" (SALIM, 2001, p. 16).

Muitas empresas funcionam sem nunca ter feito um Plano de Negócios; algumas até com muito sucesso, mas esta é sem dúvida uma opção limitadora e bastante arriscada, onde o empreendedor vai estar sempre sobre a "corda bamba".

O planejamento é muito importante dentro das empresas, pois o sucesso e a sobrevivência de muitas pessoas estão relacionados ao seu êxito, como por exemplo uma pessoa que deposita todas as suas economias no negócio que está abrindo, funcionários com famílias que dependem de seus empregos, sócios de empresas já estabelecidas que às vezes precisam fazer altos investimentos, entre outros; por isso é necessário saber muito bem o rumo a ser tomado e como chegar ao propósito.

É também por esses motivos que os administradores modernos estão usando cada vez menos, em seu dia-a-dia, intuições, ações impulsivas, e 
chegando à decisões sem base em uma análise cuidadosa de dados reais do mercado.

Para o Sebrae e ABIH- Associação Brasileira da Indústria de Hotéis (2005), no Brasil cultiva-se muito a criatividade, mas costuma-se desprezar a prática de recolher dados e usá-los para programar ações.

Deve-se perguntar: mas será que existe realmente vantagem em ser surpreendido e aproveitar as oportunidades sempre de improviso, correndo grandes riscos? Por que não crescer com um investimento planejado e calculado, ao invés de dar um salto no escuro? É para calcular os passos, minimizar riscos e aproveitar ao máximo as oportunidades que existe o Plano de Negócios, documento que descreve a empresa e até onde ela pretende chegar. Basicamente, deve conter dados sobre: planejamento, vendas e marketing, fluxo de caixa, ponto de equilíbrio, projeção do faturamento e tudo o mais que seja importante para a empresa.

Elaborar um Plano de Negócios aumenta o conhecimento que o empresário tem de sua empresa, e com isso ele encontra argumentos e mais segurança para a tomada de decisões.

No plano, não estão apenas os dados numéricos do empreendimento, estão também a filosofia de trabalho do empreendedor e os sonhos que ele quer realizar, palavras que, postas no papel, ficam mais claras e próximas de se concretizar.

Muitas vezes, um Plano de Negócios é elaborado com a intenção de obter crédito junto a um banco ou a um outro agente financeiro. Mas ele é muito mais do que isso: é um guia para o próprio empreendedor. Ele deve ser elaborado pessoalmente, pois quanto mais se conhece a empresa, melhor será seu plano.

Para entender melhor um Plano de Negócios, deve-se analisar o esquema da figura 1, que contém todas as perguntas que deverão ser respondidas ao longo da elaboração de um Plano de Negócios. 
FIGURA 1: O que deve responder um Plano de Negócios

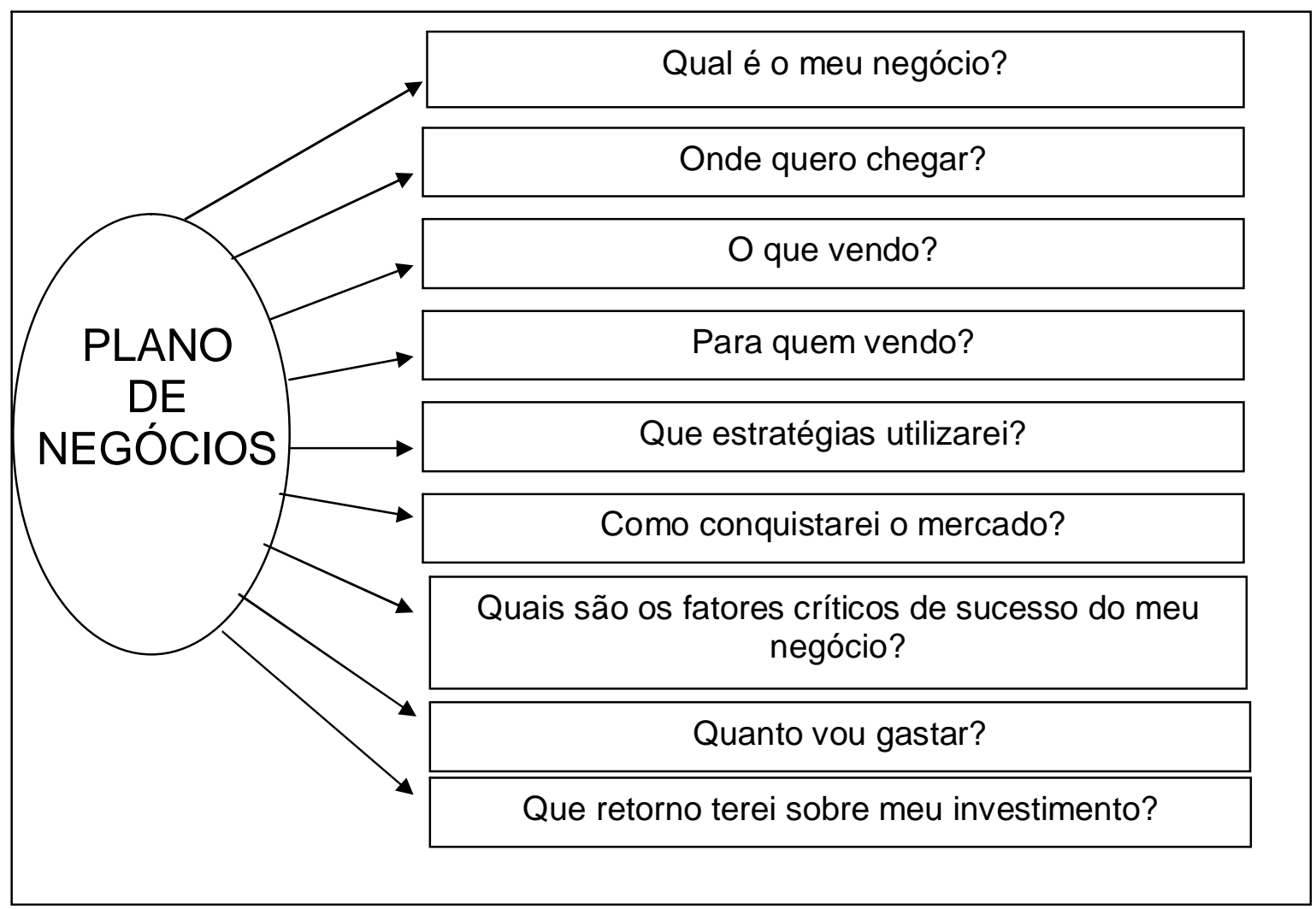

Fonte: Adaptado de Salim (2001)

É o Plano de Negócios que vai responder se o empreendimento é viável ou não, e ele é composto pelas seguintes etapas: apresentação do empreendimento que se pretende montar, o estudo da viabilidade mercadológica, o estudo da viabilidade técnica-administrativa, o estudo da viabilidade econômicafinanceira e uma análise final das três viabilidades estudadas.

Para o Sebrae e ABIH (2005), dentre os vários motivos para se elaborar um Plano de Negócios, os principais são:

Entender e dar diretrizes ao negócio;

Ajudar a gerenciar;

Monitorar o dia-a-dia;

Conseguir financiamento;

Identificar oportunidades;

Verificar viabilidade; 
Ajudar na comunicação com funcionários e parceiros;

Favorecer o convencimento de fornecedores e clientes.

É importante ressaltar que o Plano de Negócios não deve ser esquecido na gaveta depois de concluido, pois ele é uma ferramenta dinâmica que vai mudar com o mercado e o próprio desenvolvimento dos objetivos e metas da empresa.

\subsection{1- Dez Armadilhas ao Preparar um Plano de Negócios}

O Plano de Negócios é construído baseado na coleta de dados pertinentes ao empreendimento em questão, deve ser detalhado e responder algumas perguntas essenciais. Porém, durante sua elaboração deve-se evitar as 10 armadilhas mais comuns, conforme propõe Salim (2001).

1) "FAÇA UMA BOA FORMATAÇÃO DO SEU NEGÓCIO". Não basta fazer um Plano de Negócios: é necessário que o negócio esteja muito bem modelado para iniciar a etapa seguinte do Plano. Salim (2001, p. 127), diz que "o pilar básico disto tudo é ter um negócio muito bem analisado, com suas características muito bem estudadas e definidas com clareza e com suas equações financeiras completas". É indispensável que a formatação da empresa esteja feita de modo correto; negócios bem formatados são meio caminho andado para o sucesso.

2) "FAÇA SEMPRE UMA PESQUISA DE MERCADO". Sempre se tem a impressão de saber o que os outros pensam, conhecer o que o povo ou uma determinada classe ou grupo profissional deseja e o que precisa.

Quando se trata de uma empresa, não se pode imaginar a hipótese de que se é capaz de perceber ou adivinhar o que o mercado precisa, o que seria útil no momento para ajudar seus negócios. Por isso a necessidade de fazer Pesquisas de Mercado" (SALIM, 2001, p. 130).

Para o autor, as pesquisas não só quantificam informações, mas permitem identificar tendências, características que podem ser essenciais em um produto ou serviço de uma empresa. 
3) "NUNCA DEIXE DE LADO A CONCORRÊNCIA". Normalmente os empresários de pouca experiência não gostam de seus concorrentes sem nem mesmo conhece-los. Salim (2001, p. 133), define que "o fato concreto é que não se pode atuar em um mercado sem conhecer quem participa dele, os clientes, os concorrentes e os demais atores que influenciam o mercado".

Assim, não é possível fazer um bom Plano de Negócios sem conhecer profundamente os concorrentes, sua fatia de mercado, seus clientes principais, as características de seus produtos e serviços, os seus preços, e seus pontos fortes e fracos.

4) "PENSE BEM EM QUEM PODE SER SEU SÓCIO E QUAL A FORMA DE REGULAR SUAS RELAÇÕES". As sociedades muitas vezes deixam de existir pelos desentendimentos entre os sócios. Parte desses desentendimentos ocorrem quando não são estabelecidas as regras de convivência entre eles. Não se deve ter um sócio sem que antes seja bem definida a expectativa de cada um em relação ao negócio, a atuação de cada sócio, inclusive de si próprio, de modo a evitar que haja surpresas.

Segundo as idéias de Salim (2001), no início de uma sociedade, se pensa quase sempre que tudo vai ser uma verdadeira lua-de-mel pelo resto da vida, mas, com o passar do tempo, os problemas aparecem. Para que isso seja evitado, é muito importante seguir o árduo caminho de analisar bem os papéis de cada sócio, de estabelecer por escrito o que cada um pode e não pode fazer, de fixar as regras de delegação de cada sócio.

5) "ENTENDA CLARAMENTE QUEM SÃO E O PAPEL DE CADA UM DOS SEUS PARCEIROS DE NEGÓCIO". Parceiros de negócios são muito importantes no mundo atual, onde é necessário oferecer soluções completas e satisfatórias aos clientes. Para Salim (2001), é preciso estabelecer pontes de colaboração entre empresas para que, juntas, possam oferecer soluções integradas e abrangentes, objetivando maior possibilidade de êxito com seus clientes. Entretanto, é necessário que fique bastante claro para cada um dos parceiros qual a sua responsabilidade para com o outro e, sempre que possível, tais aspectos devem estar estabelecidos contratualmente. 
6) "ANALISE MUITO E COM CUIDADO SUA ESTRUTURA DE PREÇO". Uma das coisas mais difíceis para uma empresa é estabeler os preços que irá praticar. Já foi o tempo em que os preços eram fixados com base na estrutura de custos. Era mais fácil conseguir definir todos os custos envolvidos na fabricação de um produto ou na prestação de um serviço, chegando-se aos preços após colocar uma margem de lucro para remunerar a empresa.

Hoje em dia, os preços obedecem a regras de mercado: o preço é aquele que o mercado está disposto a pagar por alguma coisa, independentemente de seu custo. "O mercado, em geral, está disposto a pagar um preço que justifique o valor adicionado por aquele produto ou serviço em seu processo de negócio" (SALIM, 2001, p. 138).

7) "ESTUDE TODOS OS ASPECTOS DA FORMA DE VENDER ANALISE A CLIENTELA E ESTUDE COMO VOCÊ VAI VENDER". Para quem você vai vender, qual será sua estratégia de venda, que nichos você vai procurar conquistar, como você vai fazer para chegar até o cliente? Tudo isso já foi mostrado e deve constar no Plano de Negócios.

Entretanto, é necessário fazer muito mais do que isso: qual vai ser a imagem de sua empresa? O que o cliente deve pensar dela? Você vai atuar em algum segmento do mercado? Este segmento já está muito concorrido e até já tem ocupante principal?

Segundo Salim (2001), na hipótese de um nicho de mercado estar solidamente dominado por um concorrente, você poderia tentar dividir este nicho ou segmento em duas partes. Você poderia verificar características específicas de uma parcela dos clientes do nicho e modelar o seu produto para essa parcela. Já diziam os grandes mestres do marketing: quando você não pode dominar um segmento, divida-o em mais segmentos de forma que você possa dominar um dos subsegmentos.

8) "CONHEÇA BEM SUA ESTRUTURA DE CUSTOS E ENXUGUEA SEMPRE QUE PUDER". É essencial que a empresa gaste o dinheiro do investimento somente para manter a estrutura básica de funcionamento. Os custos de manter essa estrutura são denominados custos afundados, como o próprio nome diz, são afundados no sentido de que não retornam sob a forma de novas vendas, 
nem geram um novo serviço ou produto, e servem apenas para manter a empresa viva, vegetando. O autor defende a idéia de que:

Esses custos existem e sempre serão necessários: não é possível ter uma empresa funcionando sem um escritório, telefones, secretária, contador, despesas de impostos, mas é possível reduzi-los a um mínimo, evitando que haja desperdício, mobilizando estrutura somente quando forem conseguidos contratos que as sustentem. É necessário que se consiga gerenciar a empresa de modo que quase todos os seus custos tenham caráter produtivo (SALIM, 2001, p. 141).

Sabe-se que no mundo atual não é possível competir se a empresa estiver "inchada", isto é, sustentando pessoas desnecessárias ao trabalho, status de diretores e sócios e instalações físicas que não sejam essenciais ao seu funcionamento eficaz.

9) "ENTREgue SEMPRE, NO MíNIMO, O QUE ATENDE A EXPECTATIVA DE SEU CLIENTE”. Entregar tudo o que foi vendido é uma das regras fundamentais para a sobrevivência de uma empresa. Cumprir o prometido e o anunciado, refere-se não só a qualidade do produto e o seu bom funcionamento, mas vários outros aspectos como: prazo de entrega, serviços de instalações, suporte prometido ao cliente, manutenção oferecida, preço condizente com a qualidade e compatíveis com a concorrência, serviço de substituíção de produtos e estoque adequado, tudo deve funcionar, sempre que possível, melhor do que foi anunciado ou prometido. É preciso estar sempre atento à expectativa do cliente e não decepcioná-lo.

O autor insiste que "todo este conjunto de ações tem que ser imaginado no Plano de Negócios de tal forma a ser implementado e ter seu custo incluído no preço do produto para que seja realmente viável manter o padrão de qualidade." (SALIM, 2001, p. 144).

Constata-se que não basta um bom empreendedor para um negócio conseguir desenvolver-se e ser bem sucedido. É necessário um bom gerenciamento, capaz de utilizar com muito critério os recursos disponíveis e de desenvolver uma atitude voltada para no mínimo, não deixar os clientes sem aquilo que contrataram ou esperavam. 
10) "NÃO PENSE QUE O DINHEIRO "PINTA", ESTUDE MUITO AS NECESSIDADES E A FORMA DE SUA CAPITALIZAÇÃO". O dinheiro é muito difícil de ser obtido para empresas que estejam iniciando suas atividades. Os investidores sabem que o risco é muito alto e que o índice de mortalidade é assustador nas empresas principiantes.

"Não se pode esperar que a competição por dinheiro vá ser pequena. Os melhores competidores terão que apresentar Planos de Negócios muito bons e convincentes para merecer a escolha dos investidores de risco" (SALIM, 2001, p. 146),

Vale ressaltar que muitas vezes existe a ilusão de que basta o dinheiro inicial para abrir o negócio e que, depois, com os ganhos advindos do próprio negócio se conseguirá desenvolvê-lo. Em geral, isto não ocorre: 0 crescimento do negócio torna necessário ter cada vez mais dinheiro para investir e mudar a ordem de grandeza da empresa e sua posição no mercado.

\subsection{2- Identificando uma Oportunidade}

Segundo Degen (1989, p. 20) "a predisposição para identificar oportunidades é fundamental para quem deseja ser empreendedor". Ela consiste em aproveitar qualquer ensejo para observar negócios. O verdadeiro empreendedor enxerga oportunidades em pequenas ações e atividades do dia a dia, seja no caminho de casa, do trabalho, nas compras. É uma pessoa curiosa e sempre atenta a qualquer oportunidade de conhecer melhor um empreendimento.

Para Degen (1989) existem oito fórmulas sobre o processo de identificação de oportunidades de negócios:

Identificação de necessidade;

Observação de deficiências;

Observação de tendências;

Derivação da ocupação atual;

Procura de outras aplicações;

Exploração de hobbies; 
Lançamento de moda;

Imitação do sucesso alheio;

A identificação de necessidades consiste em procurar demandas que não estão sendo satisfeitas e desenvolver os produtos ou serviços para satisfazê-las, a um custo que os consumidores estejam dispostos a pagar.

A observação de deficiências compreende em aprimorar produtos ou serviços semelhantes, que deixem o consumidor satisfeito. Qualquer aperfeiçoamento que traga benefícios para os consumidores, torna-se uma real oportunidade de negócios.

Já a observação de tendências é o ato de acompanhar as mudanças diárias que norteiam os negócios que influenciam a empresa, para aproveitar ao máximo o potencial e evitar surpresas.

A derivação da ocupação atual é o aproveitamento do conhecimento adquirido que pode ser utilizado no novo empreendimento.

A procura de outras aplicações representa grande potencial de lucro. O empreendedor identifica problemas e procura alternativas para a solução, sejam elas mercadológicas, tecnológicas, operacionais ou financeiras.

Qualquer atividade realizada como hobbie é sem dúvida, a forma mais agradável de desenvolver um negócio próprio. Porém, com raras exceções os negócios baseados em hobbies, não se transformam em grandes empresas devido ao pouco interesse em expandi-lo. Afinal não é só gostar, empreender vai muito mais além.

No lançamento da moda os empreendimentos, na maior parte, possuem um ciclo de vida curto e rápido; ocorre quando idéias originais encantam grande número de consumidores. O encanto pode ser transposto em vários países e até mesmo ser repetido de tempos em tempos. Porém, exigem grande determinação e perseverança do empreendedor. Muitos sucessos comerciais foram considerados como "idéias malucas" e por conseqüência dessta dominação, grandes idéias não foram implantadas.

A imitação do sucesso alheio constitui a oitava e última fórmula para o processo de identificação de oportunidades de negócios. É a forma menos 
arriscada de iniciar um empreendimento próprio, sendo adotada por mais da metade dos empreendedores. É necessário identificar os fatores do sucesso e melhorá-los para que o novo negócio não constitua apenas mais um dos muitos imitadores.

\title{
2.3- Marketing
}

Antes de perceber que ajustar interesses do consumidor e do produtor era um ótimo negócio, as empresas produziam e colocavam no mercado o que elas queriam e achavam interessante; posteriormente, contratavam hábeis vendedores para tentar escoar seus produtos. Conseqüentemente, a produção superou o consumo e a concorrência aumentou assustadoramente.

Uma nova visão desse processo foi necessária, e a empresa passou a conhecer primeiro o seu mercado consumidor e o que eles desejavam, para depois fabricar o produto ou serviço. Assim, entendeu-se que a demanda deve orientar a produção.

Essa preocupação mercadológica, definida como "Marketing", passou a ser fator determinante para o sucesso das empresas, principalmente as de pequeno porte.

Castelli (1994) define marketing como o "radar" e o "oxigênio" da empresa. Até o preço, que antes era determinado por custo acrescido do lucro, passou a ser condicionado por outros fatores. Hoje, o marketing é responsável não só em saber o que o mercado quer, mas sim quanto ele quer pagar por determinado produto ou serviço, entre as outras muitas funções deste importante instrumento.

Rocha e Christensen (1999, p. 15) afirmam que:

\begin{abstract}
Marketing é uma função gerencial, que busca ajustar a oferta da organização a demandas específicas do mercado, utilizando como ferramenta um conjunto de princípios e técnicas. Pode ser visto, também, como um processo social, pelo qual são reguladas a oferta e a demanda de bens e serviços para atender às necessidades sociais. $\grave{E}$ ainda, uma orientação da administração, uma filosofia, uma visão. Essa orientação reconhece que a tarefa primordial da organização é satisfazer o consumidor, atendendo as suas necessidades, levando em conta seu bem-estar a longo prazo, respeitando as exigências e limitações impostas pela sociedade e atendendo às necessidades de sobrevivência e continuidade da organização.
\end{abstract}

De acordo com Kotler (1995), marketing é dar satisfação ao cliente de forma lucrativa; é também um processo social e gerencial através dos quais 
indivíduos e grupos obtêm aquilo que desejam e de que necessitam, criando e trocando produtos e valores uns com os outros.

Marketing é a área do conhecimento que engloba todas as atividades pertinentes às relações de troca, orientadas para a satisfação dos desejos e necessidades dos consumidores, visando alcançar determinados objetivos de empresas ou indivíduos e considerando sempre o meio ambiente de atuação e o impacto que essas relações causam no bem estar da sociedade (LAS CASAS, 1999, p. 26).

As várias definições de marketing baseiam-se nos seguintes conceitos centrais: necessidades, desejos e demandas, produtos (bens, serviços e idéias), valor, custo e satisfação.

Para Kotler (1998), é importante distinguir necessidade, desejos e demandas. Necessidade Humana é a existência de alguma necessidade básica como alimento, roupa, abrigo, segurança, auto-estima, necessidades que não são criadas pela sociedade ou por empresas.

Desejos são carências por satisfações específicas para atender às necessidades, como por exemplo, um americano precisa se alimentar e deseja hambúrguer, batata frita e coca-cola, mas essas necessidades podem ser satisfeitas de uma outra forma em uma sociedade diferente. Embora as necessidades das pessoas sejam poucas, seus desejos são muitos.

Demandas são desejos por produtos específicos, respaldados pela habilidade e disposição de comprá-los. Desejos se tornam demandas quando apoiados por poder de compra.

As pessoas satisfazem as suas necessidades e desejos com produtos que também podem ser chamados de oferta ou solução.

"Um produto ou oferta pode consistir de nada mais do que três componentes: bens físicos, serviços e idéias" (KOTLER, 1998, p. 28). O valor, por sua vez, é a satisfação das exigências do consumidor ao menor custo possível de aquisição, propriedade e uso. 
Para Kotler (1998), o marketing é responsável por impulsionar as empresas em direção ao consumidor e ao mercado. É o processo que:

Identifica necessidades;

Transforma as necessidades em produtos ou serviços;

Descobre onde estão os clientes;

Analisa a melhor maneira de alcançar os clientes;

Satisfaz as expectativas de forma lucrativa para a empresa.

Segundo o Sebrae e ABIH (2005), o marketing pode ser definido como esforço realizado no sentido de conquistar, manter e encantar clientes, que é o início, meio e fim das ações das empresas modernas.

\subsection{1- Marketing para Novos Negócios}

Durante o processo de criação e abertura de um negócio, principalmente na área de prestação de serviço, aprende-se que é imprescindível a elaboração de um eficiente e minucioso Plano de Negócios, que envolva os planos mercadológicos, técnico e econômico-financeiro.

A fase do estudo mercadológico, nada mais é que um verdadeiro estudo de marketing, pois é através dele que se obtem informações como: descrição do público alvo, análise da concorrência, localização adequada, entre outros dados obtidos por pesquisa de mercado.

O marketing apura o que os clientes desejam e tenta satisfazê-los, mantendo a lucratividade do negócio. Os estudos de marketing partem da premissa que os clientes mudam, e que a todo momento desejam inovações, tanto nos produtos como nos serviços, e o administrador deve ter habilidades para que, baseado nas análises de seus estudos de marketing, acompanhe as tendências e mudanças.

Nenhum negócio pode alcançar seus objetivos sem entender e executar os princípios de marketing e um bom projeto comercial, pois enfoca as necessidades e os desejos dos clientes, e as vendas visam as necessidades e os desejos do administrador ou empreendedor. 
Dentro da análise do Sebrae e ABIH (2005), a maioria dos pequenos empreendedores sempre dispõe de uma maior atenção para o controle do caixa, do estoque e dos preços, mas poucos se preocupam com estratégias mais amplas de marketing, pois as consideram dispendiosas e fora de alcance.

Porém, independente da circunstância, é possível que um estudo de marketing seja realizado e utilizado de forma que auxilie o administrador a satisfazer o cliente, fazê-lo sair sorrindo, pensando em voltar e recomendar o estabelecimento aos conhecidos, e ainda satisfeito com a relação custo-benefício encontrada no estabelecimento.

\subsection{2- Os 4 P's e os Eventos como Ferramenta do Marketing Promocional}

A conceituação mais ampla de marketing, que é a do conjunto de atividades humanas destinado a atender os desejos e necessidades dos consumidores por meio dos processos de troca e que, segundo Samara (1997), utiliza "ferramentas" específicas como a propaganda, a promoção de vendas, a pesquisa de marketing, a concepção de produtos, a distribuição e a logística entre outras, onde se pode concluir que para se obter êxito em marketing, na prática, é necessário muita criatividade, imaginação e emoção.

Sendo assim as bases de marketing, quando criadas, buscavam dentro da amplitude de atuação, definir elementos que demonstrassem todo o seu vasto campo em premissas que pudessem sintetizar de forma rápida e clara todo um sistema. Para isso, surgiram os 4 P's de marketing, que segundo Kotler (1995), significa:

Praça - ou localidade onde serão inseridas as ações. O produto e/ou serviço tem de ser encontrado com facilidade pelo consumidor no ponto-devenda. Para definir um bom local de instalação do negócio, é importante estudar as vantagens e desvantagens de cada possibilidade.

Preço - ação realizada frente a questão da prática de agregar um valor monetário a algo, ou seja, atribuir um valor ao que estará sendo disponibilizado no mercado. 
Produto - este é o elemento que receberá as ações. É o foco em questão, aquele que estará sendo analisado e recebendo as influências diretas dos demais P's de marketing. É aquilo que se vende. O produto e/ou serviço deve satisfazer as expextativas do consumidor.

Promoção - ações promocionais que estarão incidindo sobre certo produto e/ou serviço, de forma a estimular a sua comercialização ou divulgação. É através da promoção que uma empresa conta ao mercado que ela existe e desperta o interesse do consumidor. É a promoção que divulga os demais componentes do marketing: produto, preço e praça.

De acordo com Kotler e Armstrong (1998), uma campanha promocional deverá ter os seguintes objetivos:

Aumentar os conhecimentos do cliente a respeito da empresa;

Aumentar a percepção do cliente sobre a empresa;

Incitar os clientes a experimentar os serviços;

Obter um alto porcentual de retorno a empresa;

Criar uma certa fidelidade (clientes regulares);

Aumentar o valor médio dos serviços.

Existem diversas formas de trabalhar com a promoção de uma empresa; a propaganda pode ser de qualquer natureza, desde que objetive e alcance resultados eficientes.

O marketing está apoiado nessas quatro bases, e o estudo dos 4 Ps para o segmento de eventos também apresenta importância relevante, principalmente o P de Promoção, onde cada vez mais as empresas estão utilizando a realização de eventos como uma importante ferramenta de marketing, mas exatamente pelo marketing promocional.

Eventos como instrumento de marketing é considerado um dos mais importantes acessórios na composição dos planejamentos e táticas de ação. Grandes marcas regularmente tornam se conhecidas após a realização de eventos, onde as mesmas foram expostas ao contato com a massa. Estrategistas planejam 
com cunho cientifico o como inserir e manter a marca em evidência no mercado. (RISPOLI, 2003, p. 50).

O setor de eventos, também ganhou destaque na ampla pesquisa promovida pela InterScience para o jornal Meio \& Mensagem, sobre as "Tendências do Mercado Publicitário no Brasil", realizada com os 100 maiores anunciantes do país.

Os resultados indicaram que a propaganda vem perdendo terreno para outras ferramentas de marketing, entre as quais o setor eventos, que ocupa lugar de destaque: segunda posição entre os grandes anunciantes; terceira posição nas verbas de comunicação em 2003 e segunda posição na alocação de recursos em 2003.

Segundo Elza Tsumori, presidente da AMPRO - Associação de Marketing Promocional, o uso de eventos corporativos como ferramenta de marketing por empresas, tem alavancado outras ações promocionais relacionadas como merchandising, distribuição de brindes e outras. "O evento deixou de ser apenas um almoço ou convenção para se tornar um grande catalisador, uma forma de divulgar a marca, aproximar-se do consumidor e estabelecer um contato mais emocional."

\section{4- Formalização e Registro da Empresa}

O processo de abertura de uma empresa deve seguir algumas etapas burocráticas e é bastante complexo, pois exige análise e registro por parte de vários órgãos públicos.

O registro é um procedimento que varia de acordo com a região e com o tipo de empresa a ser aberta. Alguns estados contam com uma estrutura que centraliza todos os órgãos responsáveis pelo registro, cadastramento e legalização de empresas.

Porém, o mais comum é que o contador responsável pela futura empresa encaminhe toda documentação necessária e se encarregue dos trâmites administrativos dessa etapa de abertura. 


\subsection{1- Forma Jurídica da Empresa}

Segundo o Instituto de Apoio às Pequenas e Médias Empresas e ao Investimento - IAPMEI (2006), na legislação brasileira a escolha da forma jurídica da empresa vai determinar o seu modelo de funcionamento.

Assim, a opção por um determinado estatuto jurídico deve ser feita de modo a valorizar os pontos fortes da futura empresa tendo, no entanto, em atenção as características que melhor se adaptam às expectativas de desenvolvimento. Assim, a primeira decisão que o empresário deverá tomar é se vai desenvolver a empresa sozinho ou em conjunto com outras pessoas.

A empresa de uma pessoa só pode ter os seguintes registros:

Empresário em Nome Individual;

Estabelecimento Individual de Responsabilidade Limitada (E.I.R.L.);

Sociedade Unipessoal por Quotas.

De acordo com o Instituto de Apoio às Pequenas e Médias Empresas e ao Investimento - IAPMEI (2006), a forma mais comum de registro desse tipo de empresa é a Empresário em Nome Individual, uma empresa de uma só pessoa. O empresário (pessoa física), e a empresa (pessoa jurídica) tem uma identificação bastante forte. Nesse caso, o empresário é responsável, com seus bens pessoais, pelos atos da empresa, de forma ilimitada.

O conceito de empresário encontra-se previsto no art. 966 do novo Código Civil: É empresário quem exerce profissionalmente atividade econômica organizada para a produção ou circulação de bens ou de serviços.

O que anteriormente era chamado de Firma Individual, definida como pessoas que atuavam individualmente, sem sócio, somente para exercer atividades relacionadas à indústria ou comércio, com o novo Código Civil, a Firma Individual deu lugar ao Empresário. A diferença é que este, agora, também poderá atuar como prestador de serviços, além de exercer atividades de indústria e comércio.

Já a Sociedade empresária é aquela formada por duas ou mais pessoas. O conceito de Sociedade Empresária também é fornecido pelo novo 
Código Civil em seu art. 982: A Sociedade Empresária tem por objeto o exercício de atividade própria de empresário sujeito a registro, inclusive a sociedade por ações, independentemente de seu objeto, devendo inscrever-se na Junta Comercial do respectivo Estado.

Isto é, sociedade empresária é aquela em que duas ou mais pessoas (empresários) exercem profissionalmente atividade econômica, organizada em estabelecimento próprio e adequado para a produção ou circulação de bens ou de serviços, constituindo elemento de empresa.

De acordo com o Sebrae (2006), a legislação brasileira estabelece 5 (cinco) tipos de sociedade entre os quais a "sociedade empresária" deverá optar:

Sociedade em nome coletivo;

Sociedade em Comandita Simples;

Sociedade em Comandita por Ações;

Sociedade Anônima;

Sociedade Limitada.

As sociedades Anônima e Limitada são as mais comuns no Brasil, em virtude de a responsabilidade dos sócios ser limitada em relação às obrigações assumidas pela empresa. Os demais tipos societários possuem sócios que respondem limitadamente pelas obrigações sociais, portanto não são aconselháveis.

Segundo dados divulgados pelo Departamento Nacional de Registro do Comércio - DNRC, aproximadamente 99\% das sociedades registradas entre 1985 e 2001 foram do tipo "Sociedades por Cotas de Responsabilidade Limitada".

A "Sociedade Anônima" é mais adequada aos grandes empreendimentos, ou seja, às grandes empresas, em virtude da rigidez das normas que a regulamentam, motivo pelo qual não é uma boa opção para as pequenas empresas. A melhor opção para a pequena empresa, sem dúvida nenhuma, é o tipo Sociedade Limitada, vez que possui normas mais simples que as demais, além de preservar melhor a figura dos sócios. 
Führer (2001, p. 43) se aprofunda um pouco mais na definição da forma "LTDA" da empresa, a saber:

\begin{abstract}
$\mathrm{Na}$ sociedade por cotas de responsabilidade limitada, cada cotista, ou sócio, entra com uma parcela de capital social, ficando responsável diretamente pela integralização da cota que subscreveu, e indiretamente ou subsidiariamente pela integralização das cotas subscritas por todos os sócios. Uma vez integralizadas as cotas de todos os sócios, nenhum deles pode mais ser chamado para responder com seus bens particulares pelas dívidas da sociedade. A responsabilidade, portanto, é limitada à integralização do capital social levando em conta seu bemestar a longo prazo, respeitadas as exigências e limitações impostas pela sociedade $e$ atendidas às necessidades de sobrevivência e continuidade da organização.
\end{abstract}

\title{
2.4.2- O Nome da Empresa
}

Após a definição do tipo de sociedade em que a empresa será registrada, o próximo passo é a escolha do nome da empresa. Dependendo do tipo de sociedade escolhida, esse nome pode ser em forma de denominação social ou firma.

A sociedade limitada pode adotar firma ou denominação social como nome, sendo obrigatório que ao final do nome conste a palavra "limitada", ou sua abreviatura "Ltda.".

A firma será denominada com o nome de um ou mais sócios, desde que pessoas físicas, de modo indicativo da relação social. Ex.: José Terra e Luís Marte - Promoção e Organização de Eventos, Ltda.

A denominação deve designar o objeto da sociedade, sendo permitido nela figurar o nome de um ou mais sócios. Ex.: IMPERADOR - Promoção e Organização de Eventos, Ltda.

De acordo com o Sebrae (2006), deve-se atentar ao nome registrado, pois a omissão da palavra "Limitada", ou de sua abreviatura "Ltda.", determina a responsabilidade solidária e ilimitada dos administradores que assim empregarem a firma ou a denominação da sociedade.

A inscrição do nome da empresa (firma ou denominação social) no respectivo órgão de registro (Junta Comercial), assegura o seu uso exclusivo, no mesmo ramo de atividade, nos limites do respectivo Estado em que a empresa for registrada. Entretanto, pode-se requerer o registro no Instituto Nacional de 
Propriedade Industrial - INPI, como forma de aumentar a proteção e o uso com exclusividade do nome (marca) de sua empresa para todo o território nacional.

Após a escolha do nome em que a empresa será regsitrada, necessário se faz realizar o pedido de busca na Junta Comercial para verificar se não há outra sociedade registrada com o mesmo nome. O serviço de busca, por sua vez, pesquisa no INPI (Instituto Nacional de Propriedade Industrial) para saber se existe alguma marca registrada semelhante ao nome de sua empresa.

\subsection{3- Documentação}

Toda documentação necessária à abertura de uma empresa dependerá do tipo de registro e das exigências e particularidades dos órgãos do estado ou município.

Segundo o IAPMEI (2006), empresas do tipo LTDA (Sociedade por Quotas de Responsabilidade), que é o caso deste estudo, deverá ter no mínimo dois sócios em seu quadro societário, e apresentar contrato social, que deverá conter o objeto social da empresa (sua finalidade), capital e valor das quotas de responsabilidade de cada sócio, indicação de quem vai assinar pela empresa, retiradas e pró-labores dos sócios, imprevistos na dissolução da sociedade, sede da empresa e documentos dos sócios.

Deverá ainda conter no contrato social, obrigatoriamente para pequenas empresas, a assinatura de um advogado devidamente inscrito na $O A B$ e de duas testemunhas que não podem ter qualquer grau de parentesco com os sócios, bem como a identificação do contador da empresa.

Para que a abertura se conclua e a sociedade seja estabelecida, outros documentos são necessários como:

01 cópia autenticada do CPF e do RG de todos os sócios;

01 cópia do RG das testemunhas;

01 cópia autenticada do comprovante de residência do(s) sócio(s) gerente(s); 
01 cópia autenticada do contrato de locação do imóvel onde se instalará a empresa;

04 jogos de contrato social;

01 capa de acompanhamento da junta comercial com os seguintes formulários:

01 via do CNPJ (cadastro nacional de Pessoa Jurídica);

01 via do anexo do CNPJ (quadro societário);

01 via da Ficha de Cadastro Nacional de Empresas -modelo 1 FCN 01;

01 via da Ficha de Cadastro Nacional de Empresas -modelo 2 FCN 02;

01 via da Ficha Cadastral;

04 vias do Requerimento de Enquadramento como Microempresa (nível estadual);

\subsection{4- Junta Comercial}

$\mathrm{Na}$ Junta Comercial ocorre o registro e enquadramento como microempresa através do preenchimento da Ficha de Cadastro Nacional de Empresas - FCN 1, da Ficha de Cadastro Nacional de Empresas - FCN 2, bem como através do arquivamento do Contrato Social de sua empresa. Há ainda o Requerimento de Enquadramento do Simples para que seja aplicada a lei no que se refere à cobrança de imposto.

\subsection{5- Secretaria da Receita Federal / Secretaria Estadual da Fazenda}

Nos postos da Receita Federal e da Secretaria Estadual de Fazenda, os empresários verificam a sua situação fiscal e a de empresas nas quais tenham participação. Na Secretaria da Receita Federal ocorre a inscrição federal no Cadastro Nacional de Pessoa Jurídica - CNPJ, com o preenchimento da Ficha Cadastral da Pessoa Jurídica e do Quadro de Sócios e Administradores. 
Já na Secretaria Estadual de Fazenda, é feita a Inscrição Estadual, que só deve ser realizada após o arquivamento dos atos constitutivos (Contrato Social) da sociedade na Junta Comercial.

\subsection{6- Administração Local}

Será solicitada, pela administração local, documentação complementar para retirar o alvará de funcionamento da empresa. Para se realizar esta etapa, é necessário que todos os registros e documentações anteriormente citados estejam prontos.

\subsection{7- ABEOC - Associação Brasileira de Empresas de Eventos}

ABEOC é a Associação Brasileira de Empresas de Eventos. Uma entidade civil, sem fins lucrativos nem caráter político-partidário.

As empresas de eventos de todo o país podem optar, ou não, por ser membro da ABEOC; no entanto, sabe-se que o associativismo é o agente determinante para o fortalecimento de uma categoria profissional. Sendo assim, através da $\mathrm{ABEOC}$, as empresas organizadoras, promotoras e prestadoras de serviços para eventos podem desenvolver intercâmbio profissional, parcerias, possibilidades de negócios, aperfeiçoamento profissional, referencial de qualidade e representatividade.

Segundo os dados encontrados no site da ABEOC, as empresas que desejam se tornar membro dessa associação necessitam fazer o seguinte investimento: taxa de filiação - $R \$ 300,00$ (único), mais contribuição associativa - $R \$$ 100,00 (mensal).

A ABEOC foi fundada em 15 de janeiro de 1977, com jurisdição em todo o território nacional, e tem como finalidade coordenar, orientar e defender os interesses de seus associados, representados por empresas organizadoras, promotoras e prestadoras de serviços para eventos.

De acordo com as informações encontradas no site da ABEOC, esta assossiação tem por objetivo congregar as empresas de serviços especializados em eventos. Promover e incentivar as relações entre suas associadas no sentido de 
possibilitar intercâmbio técnico e cultural. É função da entidade também, a defesa dos interesses das associadas, tornando conhecidas, valorizadas e respeitadas as atividades profissionais do segmento. Dentro destes objetivos a ABEOC promove:

- Reuniões periódicas com suas associadas;

- Debates e palestras sobre assuntos de interesse do segmento de turismo e de eventos;

- Congresso e Exposição anual - ABEOC;

- Intercâmbio com empresários e associações de classe;

- Divulgação da profissão de organizador, promotor e prestador de serviços para eventos;

- Orientação de interessados na contratação de profissionais para eventos;

- Estímulo a observância de um elevado sentido ético nas relações entre as associadas e, entre essas e o mercado.

\subsection{8- Código de Defesa do Consumidor}

As empresas que fornecem serviços e produtos no mercado de consumo devem observar as normas de proteção ao consumidor, estabelecidas pelo Código de Defesa do Consumidor (CDC).

De acordo com a Subsecretaria do Senado Federal, o CDC foi instituído pela Lei no 8.078 , de 11 de setembro de 1990, com o objetivo de regular a relação de consumo em todo o território brasileiro, em busca do equilíbrio na relação entre consumidor e fornecedor, de forma a reforçar a posição do primeiro e limitar certas práticas abusivas impostas pelo segundo.

É importante ressaltar que o CDC somente se aplica às operações comerciais em que estiver presente a relação de consumo, isto é, nos casos em que uma pessoa (física ou jurídica) adquire produtos ou serviços como destinatário final, ou seja, é necessário que, em uma negociação, estejam presentes o fornecedor e o consumidor, e que o produto ou serviço adquirido satisfaça as necessidades próprias do consumidor, na condição de destinatário final. 
Portanto, operações não caracterizadas como relação de consumo não estão sob a proteção do CDC, como ocorre, por exemplo, nas compras de mercadorias para serem revendidas por uma empresa. Nessas operações, as mercadorias adquiridas se destinam à revenda e não ao consumo da empresa; essas negociações se regulam pelo Código Civil brasileiro e legislações comerciais específicas, e não pelo CDC.

A fim de cumprir as metas definidas pelo CDC, a empresa precisa conhecer bem algumas normas que devem ser respeitadas, tais como: forma adequada de oferta e exposição dos produtos destinados à venda, fornecimento de orçamento prévio dos serviços a serem prestados, evitar cláusulas contratuais consideradas abusivas, assumir a responsabilidade dos defeitos ou vícios dos produtos e serviços, cumprir os prazos mínimos de garantia e adotar cautelas ao fazer cobranças de dívidas.

Portanto, é imprescindivel que o empreendedor esteja sempre atento ao CDC. Ele estabelece uma série de direitos e obrigações ao fornecedor e ao consumidor.

\section{5- Turismo de Eventos}

O Turismo de Eventos tem recebido destaque relevante pelas diversas possibilidades de crescimento que tem trazido à economia do país e do mundo, por fazer parte do segmento de turismo que, de acordo com a OMT (Organização Mundial de Turismo), desde 2002, ocupa as primeiras posições como setor mais lucrativo da economia mundial.

Além disso, o Turismo de Eventos e Negócios é o segmento que mais cresce em todo o setor, pois de acordo com as pesquisas também realizadas pela OMT, dos 3,4 trilhões de dólares gerados anualmente em todo o mundo pela atividade turística, 850 bilhões sao gerados através do Turismo de Eventos, com uma taxa de crescimento anual de cerca de $30 \%$.

De acordo com definição do Ministério do Turismo, o Turismo de Negócios e Eventos compreende o conjunto de atividades turísticas decorrentes dos 
encontros de interesse profissional, associativo, institucional, de caráter comercial, promocional, técnico, científico e social.

Segundo Britto e Fontes (2002), muito mais que um acontecimento de sucesso, uma festa, uma linguagem de comunicação, uma atividade de relações públicas ou mesmo uma estratégia de marketing, o evento é a soma de esforços e ações planejadas com o objetivo de alcançar resultados definidos junto ao seu público-alvo.

Evento é uma concentração ou reunião formal e solene de pessoas e/ou entidades, realizada em data e local especial, com objetivo de celebrar acontecimentos importantes e significativos e estabelecer contatos de natureza comercial, cultural, esportiva, social, familiar, religiosa cientifica etc. (ZANELLA, 2004).

De acordo com Nora, 2004, o termo - evento - chegou até nós através do inglês "coming events", significando, em uma versão mais ampla: "vai haver um acontecimento". Porém, cronologicamente, pode-se fixar a data do primeiro "evento" em 776 a.C., na Grécia, a partir da realização da Primeira Olimpíada, em Olímpia, em honra a Zeus.

Nora, 2004, discute que desde os gregos, através dos séculos, o homem sempre viajou motivado por acontecimentos que, programados dentro de determinado espaço e tempo, são capazes de atrair verdadeiras multidões, proporcionando até mesmo o surgimento de cidades, como o das feiras medievais.

Desde então, os eventos foram se desenvolvendo e se modificando de acordo com suas necessidades e características locais.

Segundo a Secretaria de Turismo do Estado do Paraná, o Turismo de Eventos pode ser considerado um produto turístico capaz de, por si só, gerar fluxos e aumentar a estacionalidade do turista no pólo receptor, compete com o apelo motivacional das atrações naturais, culturais, ou suprir a ausência de ambas.

Como produto turístico, o evento necessita passar pelas mesmas técnicas mercadológicas utilizadas quando da promoção e lançamento de qualquer produto, com adaptações às peculiaridades do setor turístico, onde o fator diferencial é o que mais vende.

Para Nora, 2004, a conquista do público deve iniciar-se no núcleo promotor, crescendo em círculos concêntricos em direção às regiões circunvizinhas 
e ganhando amplitude à medida que o evento se fortalece, adquirindo âmbitos: estadual, nacional e internacional.

Silva, 2003, defende a idéia que em um momento que é necessário contornar os efeitos da "alta e baixa temporada", visando fomentar o turismo em diferentes épocas do ano, o Turismo de Eventos apresenta-se como uma solução ideal para os destinos turísticos. Isso porque os promotores realizam seus eventos em época de baixa temporada, quando encontram facilidades em reunir um número significativo de participantes, ao mesmo tempo em que possuem vários locais dispostos a sediá-los.

O turista não depende de férias para viajar e existem centenas de eventos que acontecem ao longo do ano, sendo possível, ainda, a criação de outros, dependendo do município ou região.

Um evento movimenta um grande número de profissionais durante a sua realização, provocando uma grande movimentação econômica nas cidades sedes. É importante observar que o turista de eventos é motivado por interesses profissionais, mesclando atividades de trabalho e lazer, tornando-se um consumidor com grande potencial de consumo do item diversão. Outro aspecto importante do Turismo de Eventos é o fato do turista retornar depois, com a família, para os locais que mais the agradaram. (SILVA, 2003).

Desta forma, o desenvolvimento do Turismo de Eventos abrange um amplo e diversificado conjunto de atividades econômicas, com importância destacada no setor de serviços, na indústria e no comércio em geral.

Portanto, segundo Silva, 2003, em termos econômicos ele pode gerar muitos benefícios, tais como incremento na receita global do local-sede do evento (um turista participante gasta três vezes mais do que um turista comum); melhora a imagem da cidade-sede do evento (o participante é um elemento divulgador do local). Além do emprego e da receita, e igualmente, melhorias na infraestrutura como conseqüência do desenvolvimento turístico.

No aspecto social, a atividade turística, em região economicamente subdesenvolvida, pode oferecer meios de manter um nível de atividade econômica, o suficiente para evitar a migração de pessoas para as áreas mais desenvolvidas de um país. 


\subsection{1- A Importância Econômica do Turismo de Eventos}

O mercado de eventos no Brasil evoluiu para um negócio bem desenvolvido nas últimas décadas, a exemplo da experiência norte-americana que ganhou destaque na avaliação de Kotler (1994, p.232). "Como um segmento baseado em estratégias, vantagens competitivas, mercados visados e uma combinação de técnicas e apelos de marketing para atingir reais ou possíveis compradores".

O setor cresce de maneira bastante acelerada, exigindo cada vez mais métodos de planejamento e organização, espaços bem equipados, profissionais especializados e marketing competitivo e eficiente na disputa por uma fatia do mercado, que de acordo com uma pesquisa realizada pelo Sebrae Nacional junto com o Fórum Brasileiro dos Convention \& Visitors Bureaux, em 2001, no Brasil são realizados, por ano, cerca de 330 mil eventos, tanto de cunho comercial como sócio-cultural ou ainda técnico-científico, envolvendo 79,9 milhões de participantes e gerando uma renda total de $\mathrm{R} \$ 37$ bilhões, representando $3,1 \%$ do PIB brasileiro.

Atualmente, muitas cidades brasileiras estão descobrindo que este é um novo nicho de mercado que, dia a dia, se destaca mais, devido a grande receita que deixa no local realizador do evento. Esse fator está encorajando muitos setores a entrar neste segmento, que lida com profissionais criteriosos na escolha do destino e dos serviços a serem contratados.

"O Brasil quer o seu próximo evento". Com esta frase, dita durante o lançamento do Plano Nacional de Turismo (PNT) em maio de 2004, o presidente Luiz Inácio Lula da Silva ressaltou a importância do Turismo de Eventos e Negócios para a economia do país.

Sabe-se que, no Brasil e no mundo todo, o turismo de eventos tem se caracterizado como uma das mais lucrativas atividades de mercado, tanto por possibilitar a ampliação da demanda na alta estação, quanto por ser alternativa mais viável para superar o vazio da baixa temporada.

Essa atividade tem se destacado na Europa, América do Norte e alguns países da Ásia, especificamente na realização de congressos, convenções, seminários, fóruns, simpósios, entre outros eventos. Na América Latina, notadamente no Brasil, os indicadores demonstram um aumento crescente, 
exigindo, cada vez mais espaços adequados, equipamentos sofisticados e, principalmente, recursos humanos qualificados e profissionalizados". (NICHOLS, 1993, p.2).

De acordo com a ideia de Nichols, acima citado, percebe-se a necessidade de enfatizar a importância econômica e educacional da indústria de eventos e a conseqüente exigência do mercado para mão-de-obra especializada e infra-estrutura adequada.

Para Lemos (2000), "O Evento não pode, apesar do nome, ser um fenômeno isolado. Dentro do processo turístico é necessária uma política de eventos inserida dentro do planejamento turístico das cidades.

Órgãos governamentais e empresas de eventos precisam trabalhar juntos e integrados em um planejamento estratégico, para que a sociedade participe e se beneficie dos resultados sociais, econômicos não sendo mera imagem ou vitrine artificial montada ou desmontada para a experimentação do fenômeno em si. Desta forma, a política de eventos deve mobilizar os valores sociais autênticos da localidade, a fim de que sejam sustentáveis e permanentes, não só o evento em si, mas o processo turístico de agregação de valor".

Acredita-se que somente a partir dessa visão citada por Lemos é que o Turismo de Eventos poderá ser um segmento favorável ao Brasil, e para as cidades que o desejam captar.

É muito importante identificar o potencial de mercado e aplicá-lo ao espaço municipal, onde tudo acontece. $\mathrm{O}$ evento deve estar adequado à infraestrutura da oferta local e manter-se em harmonia com as condições da demanda.

\subsection{2- Benefícios para as Cidades Receptoras de Eventos}

Toda vez que uma cidade é sede de um grande evento, são inúmeros os benefícios que ficam para essa cidade, pois, além da chance de ser consolidada como destino turistico, milhares de empregos são gerados.

Uma das maiores benesses que os eventos trazem às cidades, é quando os organizadores do evento conseguem elevar a auto-estima da população local e consegue envolve-la como coadjuvante em relevantes processos do evento. 
Os eventos são execelentes agentes, acessórios e possibilitadores de inserção social, contribuem com a formação de novos conceitos e proporciona chances de uma sociedade mais igual e com menos fleumas. (RISPOLI, 2003).

Os benefícios que o turismo de eventos pode trazer ao país não devem ser resumido aos grandes destinos. Na verdade, as capitais e grandes cidades brasileiras estão cada vez mais estruturadas para acolher eventos de qualquer porte, nas tipologias mais variadas.

O crescimento do setor pode ser facilmente constatado pelos impressionantes números divulgados pela pesquisa recentemente efetuada pelo Sebrae e Fórum dos Convention \& Visitors Bureau, que não deixam dúvida quanto à potencialidade das pequenas, médias e grandes cidades, cada qual procurando explorar o que tem de mais atraente e característico, consolidando, dessa maneira, sua vocação turística.

A partir daí, mediante ações dos governos federal, estaduais e municipais, devidamente engajados no mesmo propósito, o turismo de eventos pode e deve ser incentivado e direcionado às cidades do interior, utilizando-se de instrumentos apropriados e ao seu alcance, como: facilidades de acesso, bons índices de segurança, limpeza pública, sinalização adequada e infra-estrutura, isso sem deixar de contar com o apoio do empresariado local, na parte de hospedagem e atrativos de lazer e entretenimento.

De acordo com Rispoli (2003), o turismo de eventos beneficia ainda a cidade sede e, por extensão, o país pela:

- Redução da sazonalidade;

- Entrada de divisas;

- Melhoria da imagem;

- Mobilização do 'trade' turístico;

- Mobilização dos prestadores de serviços;

- Desenvolvimento socioeconômico local;

- Geração de empregos 


\section{6- Mercado de Eventos em Brasília}

Brasilia está sendo consagrada como a Capital Brasileira do Turismo de Eventos e de acordo com o Brasília e Região Convention \& Visitors Bureau (BRC\&VB), a reinaguração do Centro de Convenções Ulysses Guimarães, em 2005, tornou a capital da República ainda mais atraente para a realização de eventos de grande porte. Nos próximos quatro anos, já há 161 eventos agendados no espaço, entre congressos, feiras e workshops. Só no ano que vem, serão 79 - fora os que ainda poderão ser marcados.

O Brasília e Região Convention \& Visitors Bureau (BRC\&VB) tem papel fundamental para trazer esses eventos à cidade. Ao longo do ano, equipes da entidade fazem diversas viagens para divulgar a estrutura de Brasília pelo País e pelo mundo.

Em 2006, foram 87 eventos agendados no Centro de Convenções Ulysses Guimarães - atingindo um público total de 300 mil pessoas.

Tudo indica que a tendência é de que a capital federal se torne referência para sediar eventos, pois tem localização privilegiada, infra-estrutura moderna e 46 hotéis bem equipados - a maior parte na área central.

Outro aspecto que torna a cidade um local estratégico para a realizaçao de eventos, é o investimento que a cidade tem feito em mão-de-obra especializada em todos os serviços envolvidos. Já existe em Brasilia a Expo Eventos - a primeira "Feira de Eventos" de Brasilia, uma exposição de empresas que atuam em eventos: organizadores (cerimonial), buffet, som, luz, stands, telão, convites, bandas, grupos musicais, decoradores, efeitos especiais, casas de eventos, centro de convenções, equipamentos, roupas de festa, salão de beleza, entre outros serviços envolvidos, de forma que os clientes interessados possam conhecer em um mesmo local, todos os fornecedores que a cidade oferece e, em contra partida, fazendo com que os fornecedores se especializem e criem diferenciais para conquistar o mercado.

Segundo dados do Brasília e Região Convention \& Visitors Bureau (BRC\&VB), Brasília é reconhecida atualmente como um importante pólo de realização de eventos; segundo pesquisas, a cidade está entre as 160 melhores do mundo para a realização de eventos de negócios, possuindo o terceiro parque 
hoteleiro do país, um dos aeroportos mais modernos, centenas de agências de viagens, várias empresas organizadoras de eventos, inúmeras instituições que anualmente realizam festas de confraternização e amplos espaços para sediar encontros sociais, profissionais e políticos.

\subsection{1- Razões para Realizar um Evento em Brasília}

A cidade de Brasilia foi planejada e construída para ser a capital política do pais, o centro administrativo do Brasil. A partir daí, Brasília se desenvolveu com tanto êxito que hoje surpreende até seus criadores. Aos 45 anos, é considerada a síntese do Brasil e uma cidade aberta para o mundo, onde arquitetura, política, arte, religião, filosofia e empreendedorismo estão por todas as suas largas e amplas avenidas, pelo seu céu azul, tornando-se assim uma cidade de todos, Patrimônio Cultural da Humanidade, e pronta para sediar qualquer evento por muitos motivos, entre eles os 10 principais conforme propõe a Secretaria de Turismo do Distrito Federal:

CIDADE COSMOPOLITA: Brasília é uma cidade de braços abertos para o mundo; desde sua fundação, a cidade vem acolhendo brasileiros de todas as partes e hoje é um verdadeiro "caldeirão" de culturas típicas do país. A cidade está acostumada a receber grandes delegações; só na posse presidencial de 2003, 187 países estiveram representados; em Brasília existem 90 embaixadas e representações diplomáticas. É a segunda maior cidade das Américas em número de usuários de internet, atrás apenas de Miami, segundo a Revista América Econômica - Grupo Dow Jones (2001).

VOCAÇÃO PARA EVENTOS: por todas as suas qualidades, Brasília já está sendo considerada a capital brasileira do turismo de eventos, devido ao fato de que a cidade ja disponibiliza aos consumidores todos os atrativos $\mathrm{e}$ equipamentos turísticos necessários à realização de um evento de sucesso, ressaltando-se:

- O Centro de Convenções de Brasília;

- As dezenas de opções, entre auditórios, salas de conferências e áreas de exposição; 
- Brasília tem um dos maiores pavilhões de feiras e exposições do país, o Expocenter, com $58.000 \mathrm{~m} 2$, localizado no Parque da Cidade;

- O aeroporto internacional Juscelino Kubitschek é o terceiro maior aeroporto do país. No ano de 1996 recebeu o certificado internacional de qualidade ISO 9001.

LOCALIZAÇÃO: localizada no centro geográfico do Brasil e da América do Sul, a partir de Brasília, o visitante tem acesso fácil e eqüidistante a todas as capitais e principais cidades brasileiras, recendo atualmente 162 vôos diários procedentes dessas cidades, facilitando os deslocamentos em curtas distâncias.

REDE HOTELEIRA: uma eficiente rede hoteleira local faz com que o realizador de eventos encontre sempre a opção ideal para o que deseja. Com a presença das principais grandes bandeiras internacionais da hotelaria, os hotéis oferecem uma excelente infra-estrutura para a realização de eventos e diversas categorias de acomodações, com um total de 17 mil leitos.

FACILIDADE DE DESLOCAMENTO: por ser uma cidade planejada, criada pelo grande urbanista Lucio Costa, Brasília oferece grandes vantagens aos organizadores de eventos e a seus participantes:

Longas pistas, largas e retas criam um trânsito fluente;

A rede hoteleira está concentrada em locais estratégicos, no centro da cidade e próxima a toda a estrutura de eventos;

Os principais hotéis estão a 15 minutos do aeroporto, a 10 minutos do Setor de Embaixadas e a 5 minutos do Congresso Nacional e do Palácio do Planalto, sede do poder Executivo.

SEGURANÇA: por ser uma cidade nova, que teve seu crescimento planejado, e por ser a sede das representações diplomáticas de todo o mundo e dos três poderes da República: Executivo, Legislativo e Judiciário, Brasília é uma cidade segura para seus moradores e para seus visitantes. 
CIDADE VITRINE: na capital do país, tudo que é feito ganha grande repercussão na mídia. Todas as grandes redes de televisão, os grandes jornais e revistas brasileiros têm cobertura permanente direto de Brasília.

Os principais órgãos administrativos e de gestão pública estão sediados na cidade, o que garante agilidade e maior organização para quem está realizando um evento.

LAZER E GASTRONOMIA: opção é o que não falta em Brasília. Como sede das representações internacionais, a cidade absorveu influências das mais diversas culturas do mundo. Por outro lado, o fato de atrair brasileiros de todos os cantos do país faz com que a cidade seja uma verdadeira mistura do Brasil. Em Brasília encontra-se desde sofisticados restaurantes internacionais, até conhecidas festas folclóricas.

Brasília apresenta ótimas opções de teatros, cinemas, museus, casas de espetáculos, festas e muitas outras atrações, com um calendário de eventos culturais e artistíco bastante movimentado.

$\mathrm{Na}$ àreas de esportes, a cidade tem um dos maiores lagos artificiais do mundo, o Lago Paranoá, além de excelente estrutura para prática de esportes como o golfe e o tênis.

CLIMA: o clima na Capital do Brasil é bastante agradável, com temperaturas amenas e períodos bem definidos. Chuvoso de setembro a abril e ensolarado e seco de maio a agosto.

CIDADE MONUMENTO: andar por Brasília é conhecer as obras de um dos mais reconhecidos arquitetos de todos os tempos: Oscar Niemeyer. Suas criações fazem parte da paisagem desta cidade. Em Brasilia nao se pode deixar de visitar obras como: a Catedral de Brasilia, Palácio do Planalto, Palácio da Alvorada, Congresso Nacional, Palácio do Itamaraty, Palácio do Supremo Tribunal Federal, Memorial JK, Teatro Nacional, Palácio da Justiça, Panteão da Pátria, o Catetinho e o Parque da Cidade. 


\section{3- METODOLOGIA DE PESQUISA}

Inicialmente, foi utilizado o Método de Pesquisa Exploratória, pois foi o primeiro contato com a situação de estudo.

A pesquisa exploratória é apropriada para os primeiros estágios de investigação quando a familiaridade, o conhecimento e a compreensão do fenômeno por parte do pesquisador são, geralmente, insuficientes ou inexistentes. A pesquisa exploratória também pode ser usada como um passo inicial de um processo contínuo de pesquisa. (MATTAR, 1996).

Para Gil (1991), a pesquisa exploratória assume, na maioria das vezes, o formato de pesquisa bilbliográfica ou estudo de caso. Porém, para o desenvolvimento do projeto se fez necessário um maior aprofundamento e busca de informações sobre o tema em questão.

Em segundo momento foi utilizado o Método de Pesquisa Descritivo Quantitativo, pois realiza uma análise superficial, onde os estudos são executados através de amostras da população, utilizando-se a estatística para este fim.

Nesse método de pesquisa, os resultados são analisados e interpretados a partir das médias e percentuais das respostas obtidas.

A pesquisa Quantitativa é aquela que reúne, registra e analisa todos os dados numéricos que se referem às atitudes e aos comportamentos do públicoalvo.

Para a Pesquisa Quantitativa, o método de coleta de dados utilizado foi o questionário estruturado, o qual é composto somente por perguntas fechadas, com o intuito de facilitar as respostas dos entrevistados e proporcionar uma melhor organização para a tabulação dos dados obtidos.

O questionário utilizado na pesquisa é apresentado no apêndice $B$. Este questionário foi aplicado através de entrevista pessoal.

Após a coleta do material em referência, foi feita tabulação dos dados em com o auxilio do programa Microsoft Excel. 


\section{1- Universo e Amostra}

O Universo da pesquisa foi a populaçao de Brasilia que faz parte do publico alvo do empreendimento em estudo, ou seja, diretores de empresas que realizam eventos com freqüencia, funcionários de grandes empresas responsáveis pelo setor de eventos, funcionários do setor de eventos dos órgaos públicos, entre outros do trade turístico .

A Amostra Representativa Intencional ou por Julgamento foi composta por 80 pessoas representantes do público alvo, tendo como unidade amostral a cidade de Brasília e período de tempo Dezembro de 2006.

Nesse tipo de amostragem, o pesquisador usa o seu julgamento e conhecimento da área para selecionar os membros da população que são fontes de informação precisa.

Para Churchill (1998), a característica chave da amostragem por julgamento é que os elementos da população são selecionados intencionalmente; esta seleção é feita considerando que a amostra poderá oferecer as contribuições solicitadas.

O tipo de amostra utilizado justifica-se pela abordagem feita a um público representativo no segmento em questão, enquadrando-se perfeitamente no público alvo deste estudo.

Para alcançar o número de 80 questionários válidos, foram impressos 120 questionários, destes somente 77 foram preenchidos corretamente. Desta forma outros 3 foram impressos e aplicados para alcançar o número de pesquisas válidas para a obtenção dos dados.

Foram quantos válidos? 77 ou 80?? 


\section{4- PESQUISA DE CAMPO E ANÁLISE DE DADOS}

Trata-se de um trabalho especializado, uma vez que a pesquisa de mercado vai servir para definir tamanho, características e forma de ocupação do mercado, além das preferências do consumidor e o grau de importância atribuída a cada aspecto do negócio. Segundo Salim (2001), uma pesquisa de mercado consiste em conseguir determinar características do mercado, suas expectativas, necessidades, aceitação ou rejeição de alguma idéia, produto ou pessoa, através de um processo de consulta de uma amostra desse mercado.

Em caso do pequeno empresário não ter como pagar um especialista para realizar a pesquisa, ele terá que fazê-la por si próprio, e deverá analisar alguns aspectos importantes para que se tenha sucesso numa pesquisa de mercado:

a) escolher de modo adequado a amostra do mercado; isto vai envolver aspectos estatísticos, ou seja, que tamanho de amostra é suficientemente adequado para representar o todo;

b) o que exatamente se pretende saber na pesquisa e como transmitir adequadamente, através de perguntas que possam ser respondidas de modo fácil e rápido, evitando más interpretações;

c) como conduzir a pesquisa com a população a ser pesquisada;

d) como fazer a apuração e tabulação a partir dos dados obtidos;

A credibilidade da pesquisa depende dos seguintes fatores: precisa ser muito bem definida e os aspectos a serem pesquisados devem estar bastante debatidos e entendidos pelos empreendedores e por seus clientes, para que os resultados possam ser alcançados.

\section{1- Pesquisa Mercadológica para Embasamento do Plano de Negócios}

Com a intenção de implantar em Brasília uma agência de eventos, é necessaria a realização de uma pesquisa mercadológica, com o intuito de avaliar a viabilidade e diminuir a margem de erros e riscos no empreendimento. 
Os Objetivos Específicos desta pesquisa de campo são:

- Identificar o grau de interesse do público alvo, em utilizar os serviços e produtos de uma nova agência de eventos em Brasília;

- Identificar com qual frequência o público alvo contrata os serviços de uma agência de eventos;

- Identificar os aspectos analisados pelo público ao optarem por uma agência de eventos;

- Identificar quais os meios que o público utiliza para encontrar uma agência de eventos;

- Identificar para qual tipo de evento o público contrata uma agência para organização de evento;

- Identificar quanto o público alvo costuma gastar ao contratar uma agência de eventos.

\section{2- Análise dos Dados da Pesquisa}

Após a tabulação dos dados obtidos na presente pesquisa, pode-se analisar os resultados de uma maneira mais minuciosa, particularmente pela apresentação dos dados em forma de gráficos, permitindo assim uma melhor visualização dos mesmos.

TABELA 1: Grau de Interesse em uma Nova Agência de Eventos

\begin{tabular}{r|c|c}
\hline Grau de Interesse & F & $\%$ \\
\hline Totalmente Interessado & 51 & 63 \\
\hline Parcialmente Interessado & 23 & 29 \\
\hline Desinteressado & 6 & 8 \\
\hline Total & $\mathbf{8 0}$ & $\mathbf{1 0 0} \%$ \\
\hline
\end{tabular}


GRÁFICO 1: Grau de Interesse em uma Nova Agência de Eventos Erro!

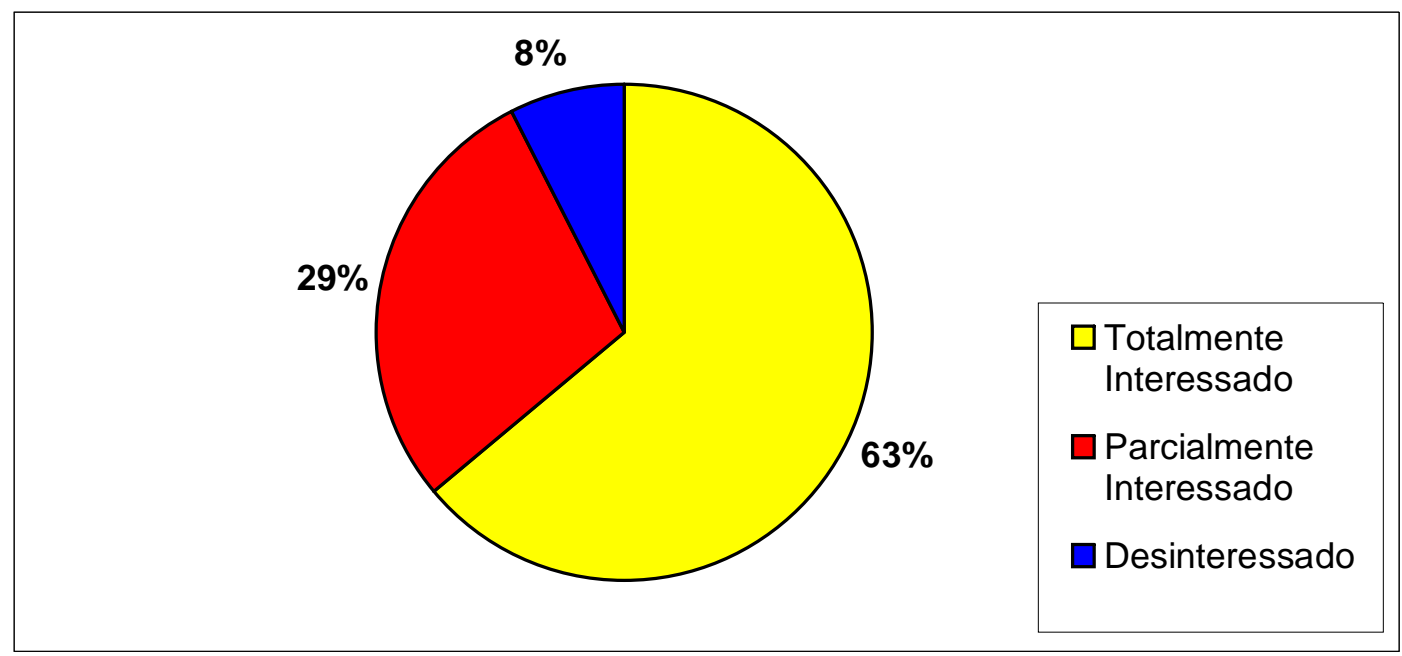

Quanto ao grau de interesse do público alvo em uma nova Agência de Eventos na cidade de Brasília que ofereça serviços nesse segmento, pode-se observar, na tabela 1 e no gráfico 1, que 63\% dos entrevistados apresentam-se totalmente interessados, enquanto uma minoria de $8 \%$ apresenta-se desinteressada, e os $29 \%$ restantes demonstram-se parcialmente interessados.

Isso representa uma grande aceitação dos consumidores que buscam cada vez mais segurança e comodidade na hora de promover o seu evento, contratando os serviços de uma empresa organizadora de eventos.

TABELA 2: Freqüência que o Público Contrata uma Agência de Eventos

\begin{tabular}{l|c|c}
\hline \multicolumn{1}{c|}{ Freqüência } & F & $\%$ \\
\hline 1 x por mês & 8 & 10 \\
\hline 1 x por bimestre & 19 & 24 \\
\hline 1 x por semestre & 29 & 36 \\
\hline 1 x por ano & 21 & 26 \\
\hline Outros $\quad$ Total & 3 & 4 \\
\hline
\end{tabular}


GRÁFICO 2: Freqüência que o Público Contrata uma Agência de Eventos

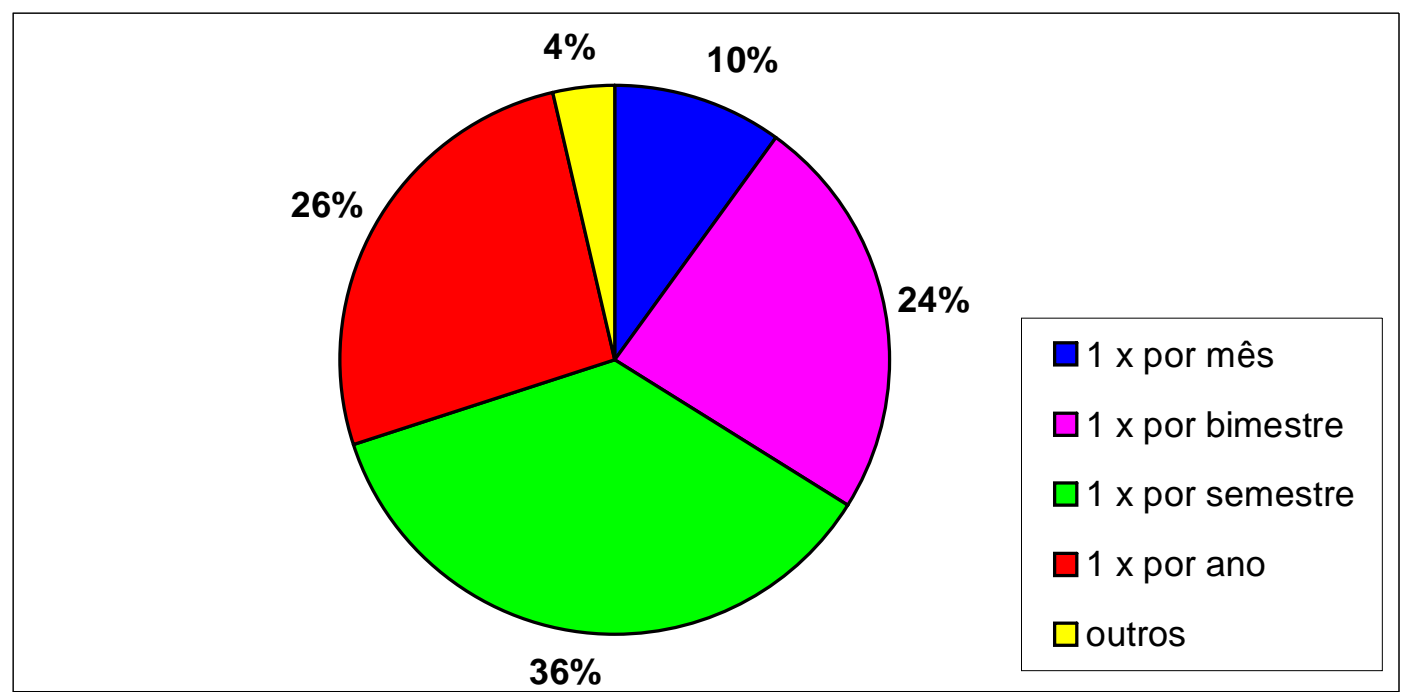

O que também comprova essa grande aceitação é o fato de que $36 \%$ dos entrevistados contratam os serviços de organização de eventos em média uma vez por semestre, $24 \%$ costuma contratar esses serviços uma vez por bimestre e $26 \%$ uma vez por ano, como mostram a tabela 2 e o gráfico 2 .

Dessa forma, existe um grande número de eventos sendo realizados em Brasilia e este número só tende a crescer com as inúmeras ações de captação de eventos que estão sendo realizadas pelo Sebrae do Distrito Federal, Secretaria de Turismo, Brasília e Região Convention and Visitors Bureau, Associação Brasileira de Indústria de Hotéis de Brasília (ABIH/DF), Associação Brasileira de Agências de Viagens do DF (ABAV/DF) e a Associação de Agências de Receptivo do Distrito Federal (ABARE), que estão unidos pelo desenvolvimento do turismo de eventos na capital do país.

Em entrevista ao Sebrae Distrito Federal, o diretor de eventos da Secretaria de Turismo, Luciano Tourinho explica que: "captações de eventos são em longo prazo, mas a ação já gera resultados imediatos".

Tourinho faz uma análise sobre a ocupação do Centro de Convenções de Brasília, que é o terceiro maior do país: "De maio de 2005, quando foi reinaugurado, a dezembro do mesmo ano, foram realizados 28 eventos no espaço. 
No ano de 2006, foram realizados 89 eventos, sendo que o Centro de Convenções não está todo pronto, faltando inaugurar quatro auditórios.

Em 2007, referido espaço já está com 95\% da agenda vendida e com reservas até 2015", e avalia: "Estamos nos transformando numa capital de eventos, o que resulta no aprimoramento das empresas de toda a cadeia, garantindo a dinamização da economia da nossa Capital".

TABELA 3: Aspectos Analisados para Escolher uma Agência de Eventos

\begin{tabular}{l|c|c}
\hline \multicolumn{1}{c|}{ Aspectos } & Total de Pontos & $\%$ \\
\hline Diversidade dos Serviços Oferecidos & 384 & 32 \\
\hline Preço & 288 & 24 \\
\hline Credibilidade da Empresa no Mercado & 240 & 20 \\
\hline Qualidade do Atendimento & 168 & 14 \\
\hline Mão de Obra Especializada & 120 & 10 \\
\hline \multicolumn{1}{c|}{ Total } & $\mathbf{1 2 0 0}$ & $\mathbf{1 0 0} \%$ \\
\hline
\end{tabular}

GRÁFICO 3: Aspectos Analisados para Escolher uma Agência de Eventos

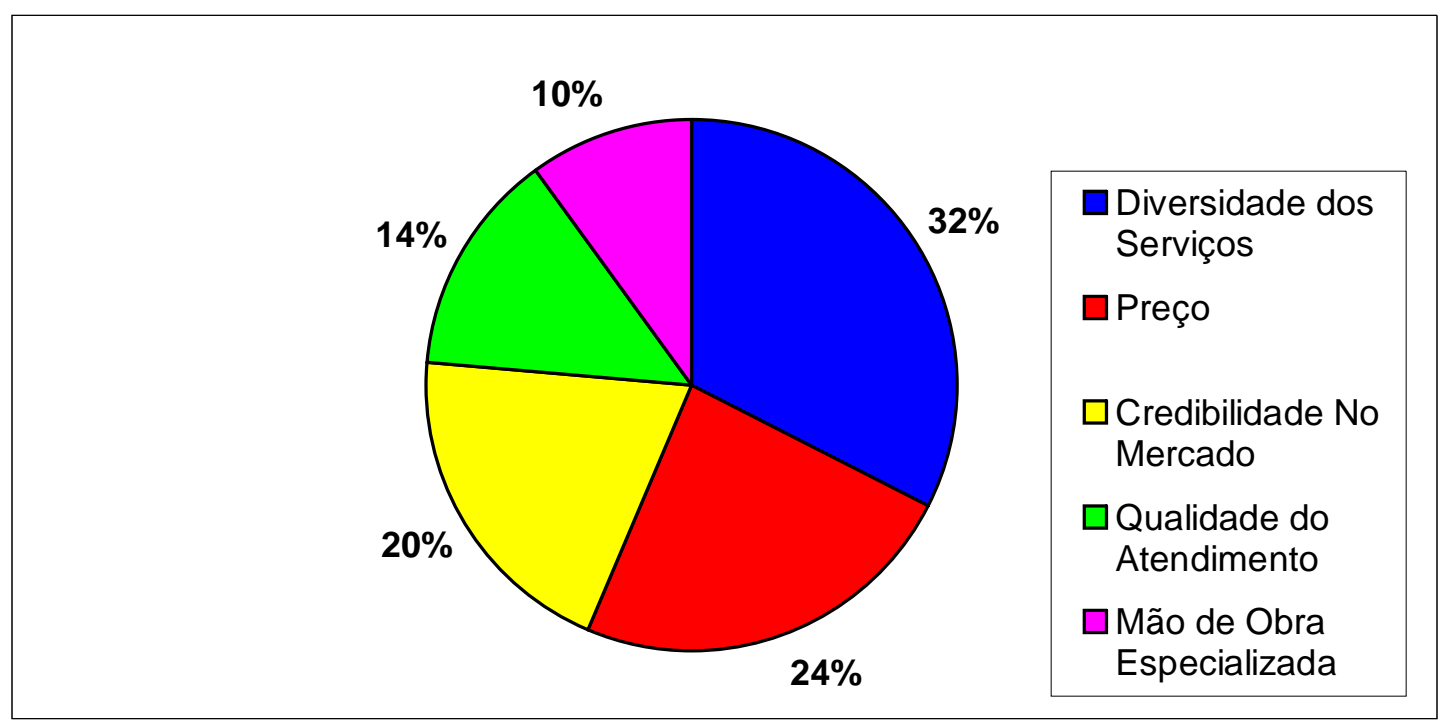

Os aspectos analisados no momento em que os consumidores optam por uma empresa de organização de eventos é um fator muito interessante, 
segundo a tabela 3 e o gráfico 3, a diversidade dos produtos oferecidos, o preço, e a credibilidade da empresa no mercado, receberam os maiores índices de importância, sendo $32 \%, 24 \%$ e $20 \%$, respectivamente. Cabe destaque a diversidade de produtos que, com um maior índice, demonstrou ser um dos aspectos decisivos na hora da escolha de uma determinada empresa.

Esses aspectos foram considerados de maior importância perante a qualidade do atendimento prestado e a qualificação da mão-de-obra.

Referida análise fornece informações essenciais no processo de formação da empresa, uma vez que ela deve ser planejada para satisfazer as necessidades e expectativas dos consumidores.

Um ponto forte levantado após a tabulação dos dados da pesquisa, é o fato de que a empresa a ser criada responde às expectativas dos consumidores no principal aspecto analisado na hora de escolher uma empresa de eventos, ou seja, a LDP Eventos será uma empresa full service, apresentará um mix de produtos e serviços bem completos, de forma que o cliente não precise se preocupar em contratar outros serviços, deixando a LDP Eventos responsável pela contratação de todos os serviços envolvidos no evento.

TABELA 4: Meios Utilizados para Encontrar uma Agência de Eventos

\begin{tabular}{l|c|c}
\hline \multicolumn{1}{c|}{ Período } & f & $\%$ \\
\hline Internet & 21 & 26 \\
\hline Indicação de Amigos & 33 & 41 \\
\hline Material Publicitário & 18 & 23 \\
\hline Lista Telefônica & 5 & 6 \\
\hline Outros $\quad$ Total & 3 & 4 \\
\hline \multicolumn{2}{c|}{$\quad$} & $\mathbf{8 0} \%$ \\
\hline
\end{tabular}


GRÁFICO 4: Meios Utilizados para Encontrar uma Agência de Eventos

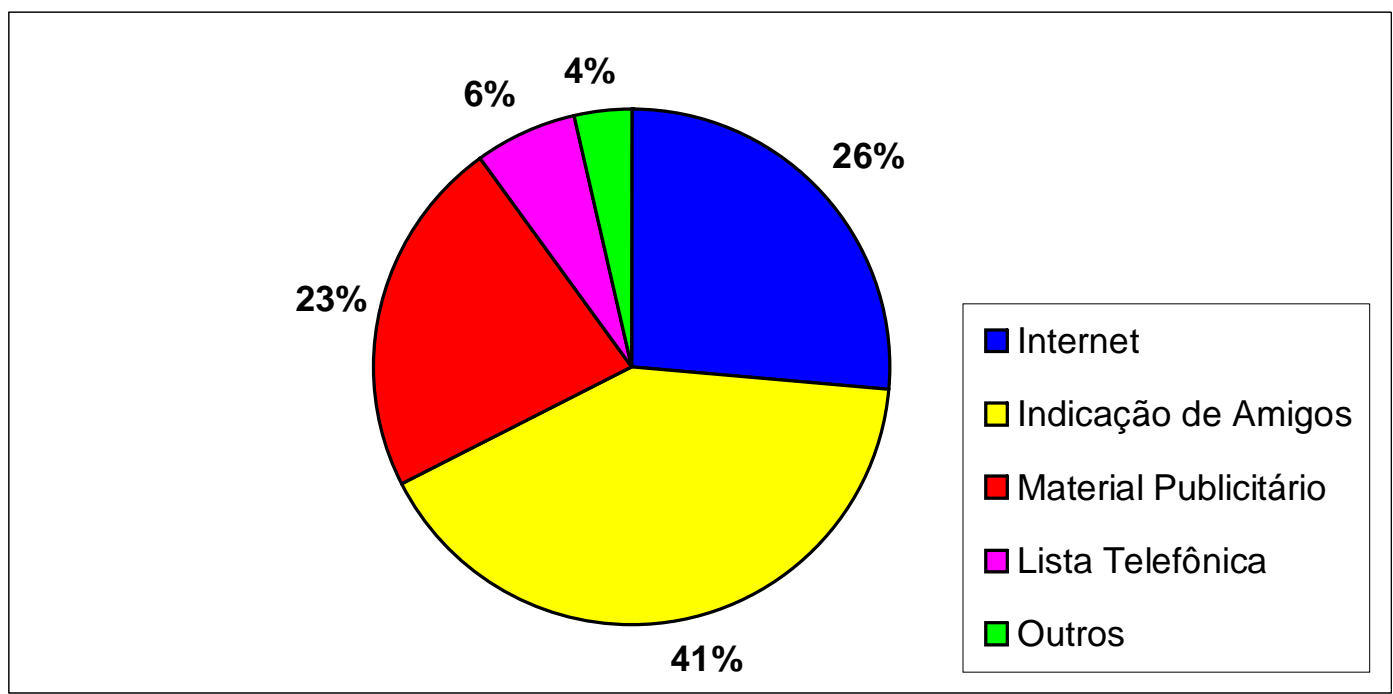

Quanto aos meios utilizados para se chegar a uma empresa prestadora de serviços de organização de eventos, a tabela 4 e o gráfico 4 mostram que $41 \%$ dos entrevistados procuram a empresa que algum amigo indicou, ou seja, confiam nos serviços que alguém de seu relacionamento já conhece e recomenda.

De acordo com a pesquisa realizada, a famosa propaganda boca a boca ainda é uma das formas mais eficazes de divulgar um determinado serviço e/ou produto.

Dessa forma, a LDP Eventos terá como diferencial um atendimento personalizado, profissional e de ótima qualidade aos seus clientes, pois clientes entusiasmados são os melhores vendedores de uma empresa.

A razão é bastante simples: os clientes não são pagos para elogiar. Quando um cliente se torna um admirador da empresa, significa que a mesma fez por merecer.

Diferentemente das respostas encontradas na questão quanto aos aspectos analisados para escolher uma empresa, onde os pesquisados analisam por último a qualidade do atendimento e a qualificação de mão-de-obra, a LDP Eventos tem como um de seus objetivos suprir essa deficiência que existe na cidade de Brasilia na prestação de serviço em geral, onde os próprios consumidores já 
estão acostumados e não exigem mais que serviços sejam prestados com excelência.

Portanto ela não será somente uma empresa que se destacará no mercado pela satisfação de seus consumidores, mas terá uma ferramenta de marketing de extrema importância - os seus clientes.

A propaganda na internet também mostrou-se uma estratégia eficaz na hora de comunicar os consumidores, $26 \%$ dos entrevistados consideraram a internet como forma de encontrar uma empresa de eventos.

Como mídia, a publicidade na Internet está se tornando uma ferramenta cada vez mais utilizada, o número de internautas que acessam a Internet no mundo e no Brasil tem crescido muito desde sua chegada. Segundo o Instituto Datafolha, em três anos o número de conectados aumentou de 7 milhões ( $7 \%$ da população ) para 23 milhões ( $19 \%$ ), considerando-se os que tem 14 anos ou mais e que usam a rede eventualmente.

Outros materiais publicitários como televisão, outdoor, rádio e revista, são responsáveis por $23 \%$ das respostas dos entrevistados e mesmo em terceiro lugar atingem uma grande parcela das pessoas.

TABELA 5: Eventos para o qual se Contrata uma Agência de Eventos

\begin{tabular}{l|c|c}
\hline \multicolumn{1}{c|}{ Produtos } & Total de Pontos & $\%$ \\
\hline Congressos ou Convenções & 56 & 20 \\
\hline Formaturas & 50 & 17,5 \\
\hline Exposições ou Feiras & 48 & 16,8 \\
\hline Lançamentos ou Inaugurações & 35 & 12,3 \\
\hline Treinamentos & 28 & 9,8 \\
\hline Casamentos & 24 & 8,4 \\
\hline Concursos ou Campeonatos & 20 & 7,0 \\
\hline Excursões & 18 & 6,3 \\
\hline Outros & 6 & 2,1 \\
\hline \multicolumn{1}{c|}{ Total } & $\mathbf{2 8 5}$ & $\mathbf{1 0 0} \%$ \\
\hline
\end{tabular}


GRÁFICO 5: Eventos para o qual se Contrata uma Agência de Eventos

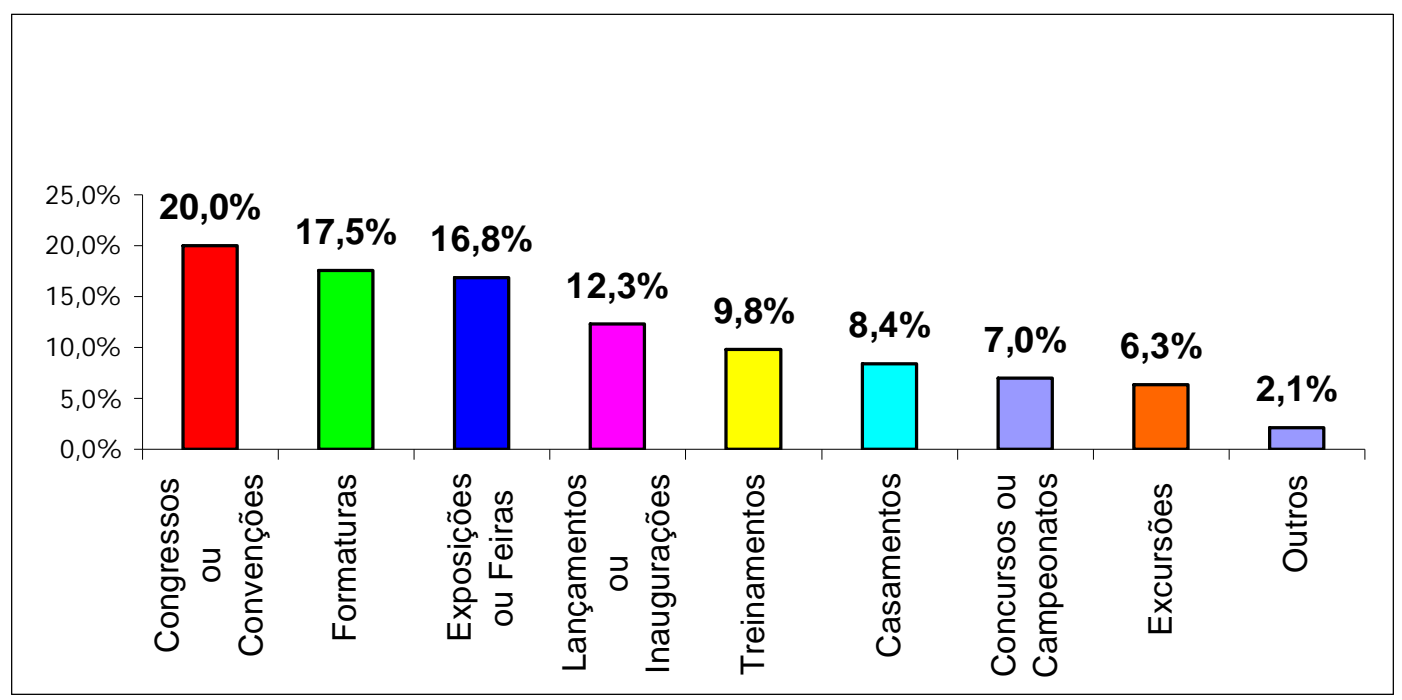

Dentre os eventos para o qual o público alvo contrata uma empresa de eventos, os três mais citados foram os congressos ou convenções com $20 \%$ das respostas, formaturas com $17,5 \%$ e exposições ou feiras com $16,8 \%$, ou seja, esses seriam os eventos que o público alvo considera como de maior necessidade de se contratar uma empresa para organiza-los.

Na seqüencia foram citados os treinamentos com $9,8 \%$, casamentos com $8,4 \%$, concursos ou campeonatos com $7 \%$, excursões com $6,3 \%$ e outros eventos com 2,1\% como mostra a tabela 5 e gráfico 5 .

TABELA 6: Valor Gasto ao Contratar uma Agência de Eventos

\begin{tabular}{c|c|c}
\hline \multicolumn{1}{c|}{ Valor } & $\mathbf{f}$ & $\%$ \\
\hline Até $R \$ 2.000,00$ & 25 & 31 \\
\hline De $R \$ 2.000,00$ até $R \$ 5.000,00$ & 29 & 37 \\
\hline De $R \$ 5.000,00$ até $R \$ 10.000,00$ & 17 & 21 \\
\hline Mais de $R \$ 10.000,00$ & 9 & $\mathbf{1 0 0} \%$ \\
\hline Total & $\mathbf{8 0}$ & \\
\hline
\end{tabular}


GRÁFICO 6: Valor Gasto ao Contratar uma Agência de Eventos

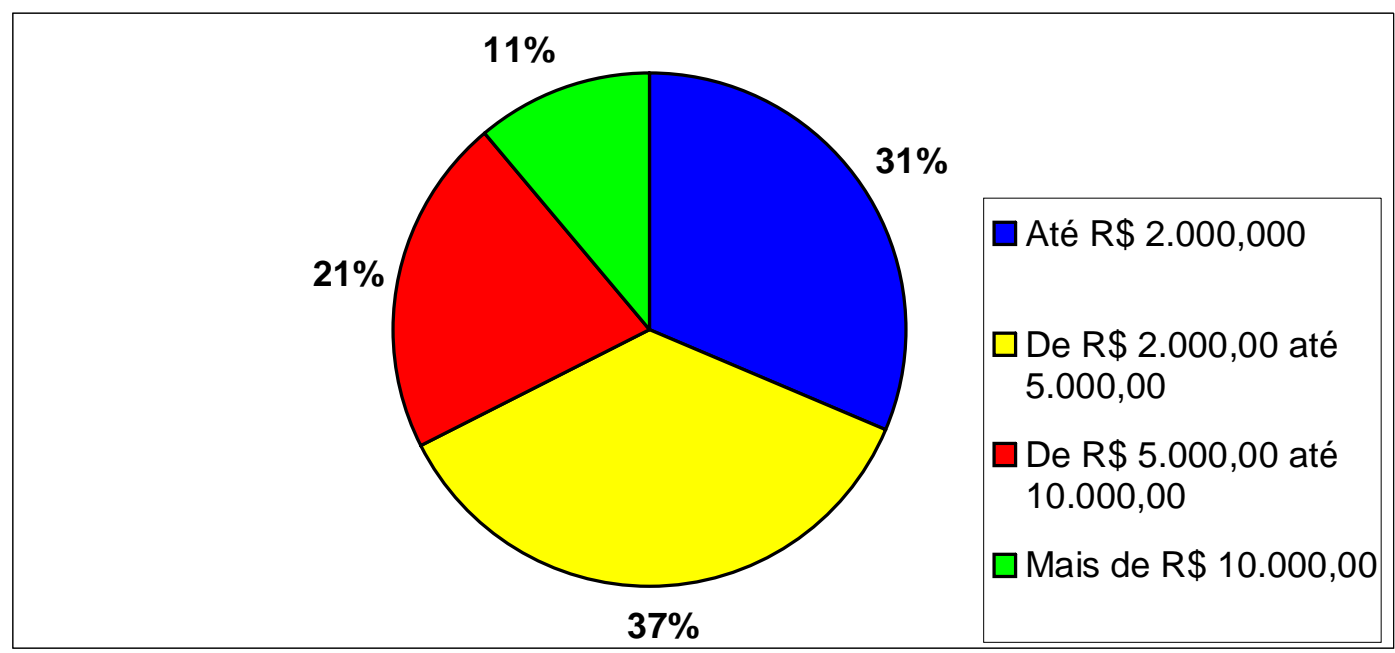

$O$ aspecto quanto ao poder aquisitivo do consumidor pode ser analisado na tabela 6 e no gráfico 6 - quando foi perguntado o quanto cada um costuma gastar para contratar uma empresa organizadora de eventos - as respostas obtidas foram que $37 \%$ dos entrevistados gastam de $R \$ 2.000,00$ a $R \$ 5.000,00$ para que uma empresa organize todos os serviços e produtos envolvidos no evento, um índice um tanto quanto expressivo.

Já o segundo maior índice foi de $31 \%$, que são pessoas ou empresas que costumam gastar até $R \$ 2.000,00$, e em seguida temos $21 \%$ e $11 \%$, que gastam de $R \$ 5.000,00$ a $R \$ 10.000,00$ e mais de $R \$ 10.000,00$, respectivamente.

Após a análise dos dados, conclui-se que os objetivos anteriormente determinados foram alcançados com sucesso, uma vez que se conseguiu obter as informações necessárias com fidedignidade, diante das opiniões dos entrevistados.

No processo de realização do presente projeto de pesquisa, encontrou-se algumas dificuldades, porém nenhuma que impedisse a realização deste projeto com sucesso.

$\mathrm{Na}$ verdade, algumas dificuldades enfrentadas, serviram para adquirir um maior número de conhecimentos. 
Respondendo assim, ao objetivo geral desta pesquisa, conclui-se que o empreendimento em questão é viável mercadologicamente, apresentando êxito e sucesso em todos os passos desta análise.

\section{3- Estimativa da Receita}

A projeção de vendas é feita, em geral, com base em pressupostos que são obtidos através da pesquisa de mercado realizada e dados fornecidos por órgaos oficiais. Assim pode-se estimar o fluxo mensal de eventos realizados e o gasto médio ao contratar uma empresa organizadora de eventos.

Partindo-se desses valores e de algumas premissas sobre a participação de mercado que será obtida pelo empreendimento, obtém-se a receita mèdia mensal da LDP Eventos. No quadro 1, apresenta-se os dados e os cálculos da estimativa da receita.

QUADRO 1: Memória de Cálculo da Estimativa da Receita

\begin{tabular}{|c|c|c|c|c|}
\hline \multicolumn{4}{|c|}{$\begin{array}{l}\text { Média de Eventos Realizados por Mês em Brasília } \\
\text { Fonte: Pesquisa Sebrae - DF }\end{array}$} & 666 \\
\hline \multicolumn{4}{|c|}{$\begin{array}{l}\text { Numero de Empresas Organizadoras de Eventos em Brasília } \\
\text { ( } 58 \text { registradas e cerca de } 40 \text { que trabalham na informalidade) }\end{array}$} & 98 \\
\hline \multicolumn{4}{|c|}{$\begin{array}{l}\text { Media de Eventos realizados por Mês por cada Agencia de Eventos - (666 } \\
\text { eventos divididos por } 98 \text { empresas) }\end{array}$} & 6.8 \\
\hline \multicolumn{4}{|c|}{ Cálculo do valor gasto por consumidor por evento - Base 80} & \\
\hline Valor Gasto & Valor Médio & $\begin{array}{l}\text { Consumidores } \\
\text { por Valor }\end{array}$ & $\begin{array}{l}\text { Valor Total por } \\
\text { Faixa de Gasto }\end{array}$ & \\
\hline Até $\mathrm{R} \$ 2.000$ & $\mathrm{R} \$ 1.000$ & 25 & $\mathrm{R} \$ 25.000$ & \\
\hline$R \$ 2.000$ a $R \$ 5.000$ & $R \$ 3.500$ & 29 & $\mathrm{R} \$ 101.500$ & \\
\hline$R \$ 5.000$ a $R \$ 10.000$ & $\mathrm{R} \$ 7.500$ & 17 & $\mathrm{R} \$ 127.500$ & \\
\hline Mais de $\mathrm{R} \$ 10.000$ & $\mathrm{R} \$ 10.000$ & 9 & $\mathrm{R} \$ 90.000$ & \\
\hline TOTAL GERAL & & 80 & $\mathbf{R} \$ 344.000,00$ & \\
\hline \multicolumn{4}{|c|}{ Gasto Médio Por Consumidor Por Evento (344.000/80) } & $R \$ 4.300 .00$ \\
\hline \multicolumn{4}{|c|}{ Receita Média Mensal na LDP Eventos (R\$ 4.300 .00 x 6.8 Eventos) } & $R \$ 29.240 .00$ \\
\hline
\end{tabular}


Para formar a estimativa da receita, partiu-se do pressuposto de quantos eventos sao realizadas na cidade de Brasilia por mês. De acordo com uma pesquisa realizada pelo Sebrae, em conjunto com o Fórum Brasileiro dos Convention e Visitors Bureaux (FBC\&VB) constatou-se que no DF são realizados anualmente mais de 8.000 eventos com uma média 666 por mês.

O numero de empresas que atuam no mercado de Brasilia é de 98, sendo 58 legalmente regsitradas nos órgaos responsáaveis, como já citado no item competidores, e aproximadamente 40 empresas que trabalham na informalidade.

Frente a esses dados, conclui-se que cada empresa realiza cerca de 6.8 eventos por mês, considerando que as empresas possuem uma mesma fatia de mercado.

Para efeito do cálculo do valor do gasto médio, tranformou-se as faixas de valores em valor único de gasto, com a seguinte correspondência: atè $R \$$ $2.000,00$, igual a $R \$ 1.000,00$; de $R \$ 2.000,00$ a $R \$ 5.000,00$, igual a $R \$ 3.500,00$; de $R \$ 5.000,00$ a $R \$ 10.000,00$, igual a $R \$ 7.500,00$; e acima de $R \$ 10.000,00$, igual a $\mathrm{R} \$ 10.000,00$.

Através desses valores únicos e o número de entrevistados correspondentes a cada faixa, encontrou-se o gasto médio por consumidor por evento, chegando ao valor de $\mathrm{R} \$ 4.300 .00$.

Considerando que este projeto pretende posicionar o negócio em questão na media do setor, pode-se considerar a realizaçao de 6.8 eventos por mês, chegando a uma estimativa de receita mensal da ordem $R \$ 29.240 .00$. 


\section{5- O EMPREENDIMENTO}

A LDP Eventos será uma agência de eventos, ou seja, uma empresa prestadora de serviços em planejamento, organização e execução de eventos empresariais, corporativos e sociais, tais como reuniões, congressos, treinamentos, workshops, confraternizações, casamentos, formaturas e demais tipos de eventos.

Será uma agência "full service", pois trabalhará de forma integrada e flexível, oferecendo todos os serviços necessários para que o evento seja um sucesso: do local adequado ao serviço de alimentos e bebidas, da decoração à segurança, dos recursos audiovisuais à confecção e distribuição de convites, sem esquecer da assessoria de imprensa; cuidará de cada detalhe.

Terá como principal caracteristica a personalização de serviços, bom atendimento e qualidade, estabelecendo-se no mercado como referência em prestação de serviços para eventos.

Sua Missão será:

Criar ambientes adequados para o encontro de pessoas e idéias, buscando solução completa para todos os detalhes.

Seus pricipais valores serão:

- Proporcionar ao cliente segurança e tranquilidade;

- Manter sempre a relação de confiança e respeito com nossos clientes e fornecedores;

- Ser um espaço de valorização e reconhecimento profissional;

- Catalisar o bem estar da equipe;

- Crescer e aprender com humildade;

- Concorrer com ética no mercado.

A partir de sua missão e seus valores, a LDP Eventos está capacitada a realizar todas as atividades de planejamento, coordenação, infraestrutura, consultoria e organização de eventos, em cada uma das etapas ou qualquer delas isoladamente. 


\section{6- VIABILIDADE MERCADOLÓGICA DO EMPREENDIMENTO}

Neste capítulo busca-se estudar o mercado, que por sua vez, deve apresentar-se em escala adequada e a preços realistas e compatíveis com os já praticados.

A avaliação do desempenho da concorrência, tendências e tecnologias disponíveis contribuem de maneira decisiva para a análise desta viabilidade.

A análise de mercado também é muito importante, pois se até um consumidor comum faz pesquisa prévia para verificar as melhores opções, quanto mais uma empresa que vai colocar em jogo um volume maior de capital e as próprias perspectivas profissionais.

Uma análise de mercado que integra o Plano de Negócios demonstra que o empreendedor está atento às variáveis do mercado, e não se baseia apenas em suas boas idéias.

A análise pode dar uma visão sobre as condições que a empresa tem para ingressar no mercado e sobre a conveniência de se investir nela.

Nesta parte do Plano de Negócios, pretende-se fazer uma análise completa dos mercados, dos concorrentes, dos parceiros, e principalmente de uma pesquisa de campo, procurando segmentar os mercados e avaliar a forma de abordagem que deve ser dada a esse segmento, no qual se pretende atuar.

É através dessa análise que será concluída ou não a viabilidade mercadológica do empreendimento em questão.

\section{1- Mercado}

Para se constatar a existência do mercado para esse empreendimento, alguns pontos devem ser discutidos, como a localização, público alvo, competidores e se realmente existe um nicho de mercado, que será comprovado neste capítulo. 


\subsection{1- Localização}

A localização física de uma empresa tem sua importância relacionada com o que se pretende vender e com o mercado-alvo.

Para uma empresa como a LDP Eventos, é muito importante que a sua localização seja acessível ao seu público alvo e apresente estruturas compatíveis com o mesmo.

Sendo assim, a LDP Eventos terá como área geográfica de mercado a cidade de Brasília e será localizada na região central da cidade, no Complexo Brasil XXI, uma área privilegiada, com 200 mil metros construídos entre o Parque da Cidade e a Torre de TV, ocupando toda uma quadra do Setor Hoteleiro Sul.

O Complexo Brasil XXI é formado por 7 prédios, estando 4 deles concluídos e 3 em obras, um subsolo-garagem com capacidade para 1250 carros que permite acesso direto dos passageiros a quaisquer dos blocos, e um heliponto. Por estar no centro de Brasília, em cinco minutos se vai com facilidade aos principais pontos da cidade.

Prédios Concluídos:

- Meliá Tryp Park - BI. F - Hotel

- Bussines Center Park - BI.E - Torre de Escritórios

- Meliá Brasília - Bl. D - Hotel

- Business Center Tower - BI. C - Torre de Escritórios

Prédios em Obras:

- Centro de Convenções

- Centro Empresarial Brasil XXI - BI. A

- Brasil XXI Suítes - BI. B

$O$ apêndice $A$ apresenta uma foto aérea do complexo Brasil XXI e o seu entorno, onde será instalada a empresa LDP Eventos. 


\subsection{2- Público Alvo}

O público alvo será composto por pessoas físicas e jurídicas que necessitam realizar eventos de qualquer natureza na cidade de Brasília e buscam empresas organizadoras de eventos para planejá-los, organizá-los e executá-los, assegurando o sucesso dos mesmos.

Quando pessoa física, o público será formado predominantemente por uma classe social média-alta e alta, ou seja, classe B, A e AA. Quando pessoa jurídica, este público será formado por empresas de médio e grande porte, órgãos governamentais e internacionais, classes profissionais e ONGs.

Para realizar uma análise mais profunda deste público que formará o mercado, é necessário que alguns dados sejam verificados.

De acordo com dados do Brasília e Região Convention \& Visitors Bureau, Brasília detem a maior renda per capita do país, que chega a atingir o dobro da média brasileira. Por isso, Brasília desponta como a quarta cidade brasileira entre aquelas de maior poder de consumo.

Por este lado, observa-se uma grande camada da população como público alvo da empresa em questão, pois são pessoas que possuem um poder aquisitivo alto, e procuram esses empreendimentos como alternativa de obter um evento de qualidade e satisfação a todos nele envolvido.

Sendo assim, pode-se antecipar que a demanda existe, porém, deverá ser melhor examinada na pesquisa de mercado.

\subsection{3- Concorrentes}

A concorrência preocupa a maioria dos novos empresários. Porém muito pior que a concorrência, é a falta de competitividade da empresa.

Brasília possui 58 agências de eventos, que oferecem os mais variados serviços para organização de eventos, devidamente registradas no Ministério do Turismo e na Secreteria de Turismo do Distrito Federal, bem como cerca de outras 40 empresas que prestam serviço nesse segmento mas que trabalham na informalidade. 
No quadro 2, segue a relação das 58 empresas organizadoras de eventos em Brasilia, registradas no Ministério do Turismo e Secreteria de Turismo do Distrito Federal, para que se tome conhecimento dos principais concorrentes, porém o empreendedor não deve se ater somente a estes competidores.

QUADRO 2: Empresas Competidoras

\begin{tabular}{|c|c|}
\hline & EMPRESA \\
\hline 01 & $\begin{array}{l}\text { A \& C EVENTOS } \\
\text { Endereço: Setor Hoteleiro Sul quadra } 06 \text { conjunto A bloco C salas } 305 \text { a } 308 . \\
\text { Ed. Business Center II - Complexo Meliá Brasília - Asa Sul } \\
\text { Telefone: }+55 \text { (61) } 3322.2626 \text { Fax: }+55 \text { (61) } 3322.4512 \\
\text { E-mail: aeceventos@aeceventos.com.br } \\
\text { Horário de Funcionamento: } 9 \mathrm{~h} \text { às } 19 \mathrm{~h}\end{array}$ \\
\hline 02 & $\begin{array}{l}\text { AGENDA EVENTOS } \\
\text { Endereço: Setor de Rádio e Tv Norte, qd 701, conjunto P, Ed. Brasília Rádio } \\
\text { Center salas } 30 / 60 \text { - Asa Norte } \\
\text { Telefone: }+55 \text { (61) 3328.2090 Fax: }+55 \text { (61) 3328-2091 } \\
\text { E-mail: agendaeventos@o2.net.br } \\
\text { Horário de Funcionamento: } 9 \mathrm{~h} \text { às } 18 \mathrm{~h}\end{array}$ \\
\hline 03 & $\begin{array}{l}\text { AGORA ELES PROMOÇÕES } \\
\text { Endereço: SHIS DL 06/08 Conjunto E - Térreo } \\
\text { Telefone: }+55 \text { (61) 3364-0000 } \\
\text { E-mail: parkshow@terra.com.br }\end{array}$ \\
\hline 04 & $\begin{array}{l}\text { AMARILIS COMUNICAÇÃO E EVENTOS } \\
\text { Endereço: Setor Comercial Local Sul 705/905, Edifício Mont Blanc - Asa Sul } \\
\text { Telefone: }+55(61) 3443-8658 \text { Fax: }+55(61) 3443-8658 \\
\text { E-mail: amarilisltda@zaz.com.br } \\
\text { Horário de Funcionamento: } 9 \mathrm{~h} \text { ás } 19 \mathrm{~h}\end{array}$ \\
\hline 05 & $\begin{array}{l}\text { APLAUSO } \\
\text { Endereço: Setor de Rádio e Televisão Norte, qd 701, cj c n 124, sala } 531 \\
\text { Telefone: +55 (61) 3327-4044 Fax:+55 (61) 3328-2752 } \\
\text { E-mail: aplauso@aplausoeventos.com.br } \\
\text { Horário de Funcionamento: } 8 \text { h30 às } 18 \mathrm{~h}\end{array}$ \\
\hline 06 & $\begin{array}{l}\text { APOIO CONGRESSOS LTDA. } \\
\text { Endereço: SAAN quadra 3, lotes 70/80 } \\
\text { Telefone: +55 (61) 3234-8181 Fax: }+55 \text { (61) 3234-8181 } \\
\text { E-mail: apoio@apoio.inf.br } \\
\text { Horário de Funcionamento: } 8 \text { h ás } 18 \mathrm{~h}\end{array}$ \\
\hline 07 & $\begin{array}{l}\text { ARPROM } \\
\text { Endereço: ADE Conj } 25 \text { lote } 09 \text { Águas claras } \\
\text { Telefone: +55 (61) 3399-8228 Fax: +55 (61) 3399-8229 } \\
\text { E-mail: arpromdf@terra.com.br }\end{array}$ \\
\hline 08 & $\begin{array}{l}\text { ARTWAY } \\
\text { Endereço: Setor Comercial Sul, quadra 8, bloco B, } 50 \text { S/79, Ed. Venâncio } 2000 \\
\text { Telefone: }+55 \text { (61)3322-7510 Fax: }+55 \text { (61) 3322-7510 } \\
\text { E-mail: artway@artway.com } \\
\text { Horário de Funcionamento: } 8 \text { h às } 18 \mathrm{~h}\end{array}$ \\
\hline 09 & $\begin{array}{l}\text { ATHOS EVENTOS } \\
\text { Endereço: SCS Qd. } 01 \text { Bloco C № } 30 \text { sala 703/704 - Ed. Antônio Venâncio Silva } \\
\text { Telefone: +55 (61) 3226-2931 Fax: +55 (61) 3321-6628 } \\
\text { E-mail: athos10@terra.com.br }\end{array}$ \\
\hline 10 & $\begin{array}{l}\text { AUÊ PROMOÇÃO } \\
\text { Endereço: SC/Norte Qd. } 5 \text { BI A no50 SI } 719 \text { Ed. Brasília Shopping } \\
\text { Telefone: +55 (61) 3326-8970 Fax: +55 (61) 3326-8970 } \\
\text { E-mail: monica@auepromocão.com.br }\end{array}$ \\
\hline
\end{tabular}




\begin{tabular}{|c|c|}
\hline 11 & $\begin{array}{l}\text { BRASIL EVENTOS } \\
\text { Endereço: SHCN } 310 \text { Bloco C № } 36 \text { loja } 216 \\
\text { Telefone: +55 (61) 3340-0612 } \\
\text { E-mail: brasileventos@terra.com.br }\end{array}$ \\
\hline 12 & $\begin{array}{l}\text { BRAWNER TOUR } \\
\text { Endereço: SH/SW CCSW } 05 \text { Lote } 02 \text { Bloco } 1 \text { Loja } 91 \text { Semienterrado } \\
\text { Telefone: +55 (61) 3034-0441 Fax: +55 (61) 30340441 } \\
\text { E-mail: brawner.tour@gmail.com } \\
\text { Site: www.brawnertour.com.br }\end{array}$ \\
\hline 13 & $\begin{array}{l}\text { COMUNICATO RECEPÇÃO E ORGANIZAÇÃO DE EVENTOS } \\
\text { Endereço: SEPS 705/905 Bloco A sala } 422 \text { - Centro Empresarial Santa Cruz } \\
\text { Telefone: +55 (61) 3242-6569 Fax: +55(61) 3242-9033 } \\
\text { E-mail: comunicato@brturbo.com }\end{array}$ \\
\hline 14 & $\begin{array}{l}\text { CSRN - ASSESSORIA E CERIMONIAL } \\
\text { Endereço: SHIS/SUL QI } 11 \text { Bloco O o } 85 \text { salas 209/210 } \\
\text { Telefone: }+55 \text { (61) 3364-1017 } \\
\text { E-mail: csrm@solar.com.br }\end{array}$ \\
\hline 15 & $\begin{array}{l}\text { DIAMOND EVENTOS } \\
\text { Endereço: SHIS QI } 21 \text { Conjunto } 06 \text { Casa } 16 \\
\text { Telefone: +55 (61) 3366-4166 } \\
\text { E-mail: diamond@tba.com.br }\end{array}$ \\
\hline 16 & $\begin{array}{l}\text { DIVENTS } \\
\text { Endereço: SAAN Qd. } 03 \text { Lote } 65 \\
\text { Telefone: +55 (61) 3234-1600 Fax: +55 (61) 3234-0749 }\end{array}$ \\
\hline 17 & $\begin{array}{l}\text { ELO CONSULTORIA } \\
\text { Endereço: Setor Comercial Norte, quadra 2, bloco A, Ed. Corporate Center } \\
\text { Telefone: +55 (61) 327-1142 / } 3281390 \text { Fax: +55 (61) } 33281390 \\
\text { E-mail: elo@eloconsultoria.com.br }\end{array}$ \\
\hline 18 & $\begin{array}{l}\text { ESTAÇĀO UM } \\
\text { Endereço: SHS Qd. } 05 \text { Bloco H } 2 \text { Sala } 01-\text { Subsolo } \\
\text { Telefone: +55 (61) 3319-4943 Fax: +55 (61) 3225-6668 } \\
\text { E-mail: eventos@estacaoum.com.br }\end{array}$ \\
\hline 19 & $\begin{array}{l}\text { EVENTHUS } \\
\text { Endereço: Colônia Agrícola Vicente Pires Chácara no } 311 \text { lote } 20 \\
\text { Telefone: +55 (61) 3397-1918 Fax: +55 (61) 3036-1295 } \\
\text { E-mail: elizabethcupertino@terra.com.br }\end{array}$ \\
\hline 20 & $\begin{array}{l}\text { EXEMPLUS } \\
\text { Endereço: SIG Q.08 № } 2268 \text { St. Ind. Gráficas } \\
\text { Telefone:+55 (61) 3343-3361 Fax: +55 (61) 3344-3798 } \\
\text { E-mail: exemplus@uol.com.br }\end{array}$ \\
\hline 21 & $\begin{array}{l}\text { EXITO PROMOÇAO DE EVENTOS } \\
\text { Endereço: SHCS EQ 102/103 Bloco A loja } 20 \text { - Cine Centro São Francisco } \\
\text { Telefone: +55 (61) 224-7818 Fax: +55 (61)3321-3694 } \\
\text { E-mail: msturismo@zaz.com.br }\end{array}$ \\
\hline 22 & $\begin{array}{l}\text { FLASHWORLD } \\
\text { Endereço: SGAS } 915 \text { Conj B Bloco A Sala } 11 \text { - Subsolo } \\
\text { Telefone: +55 (61) 3346-7838 Fax: +55 (61) 3345-6914 } \\
\text { E-mail: flashworld@terra.com.br }\end{array}$ \\
\hline 23 & $\begin{array}{l}\text { FOR ROCK PROMOÇŌES } \\
\text { Endereço: SHIS QI 09 Bloco C Sobreloja } 06 \\
\text { Telefone: +55 (61) 3248-6240 Fax: +55 (61) 3248-1444 } \\
\text { E-mail: full.time@brturbo.com }\end{array}$ \\
\hline 24 & $\begin{array}{l}\text { GRUPO LABOR } \\
\text { Endereço: SRTVS Qd. } 701 \text { Conj L Bloco } 01 \text { Loja } 12 \\
\text { Telefone: +55 (61) 3321-7440 Fax: +55 (61) 3225-0347 } \\
\text { E-mail: Ana Paula@grupolabor.com.be }\end{array}$ \\
\hline 25 & $\begin{array}{l}\text { GOUVÊA \& EICHLER MARKETING PROMOCIONAL } \\
\text { Endereço: SCN QD. 02 Bloco D Salas 625/627 - Torre A } \\
\text { Telefone: +55 (61) 3328-4147 Fax: +55(61) 3327-2498 } \\
\text { E-mail: gouvêa.eicher@zaz.com.br }\end{array}$ \\
\hline
\end{tabular}




\begin{tabular}{|c|c|}
\hline 26 & $\begin{array}{l}\text { HT COMUNICAÇÃO } \\
\text { Endereço: SCS Qd. } 02 \text { Bloco C № } 99 \text { Sala } 306 \text { - Ed São Paulo } \\
\text { Telefone: +55 (61) 3201-0487 Fax: +55(61) 3224-1520 } \\
\text { Email: jorgepaesleme@bol.com.br }\end{array}$ \\
\hline 27 & $\begin{array}{l}\text { IBEG } \\
\text { Endereço: SQS } 116 \text { Bloco J Apt } 603 \\
\text { Telefone: +55 (61) 3037-8018 Fax: +55 (61) 3963-9122 } \\
\text { E-mail: ibeg@ibeg.com.br }\end{array}$ \\
\hline 28 & $\begin{array}{l}\text { IBDM } \\
\text { Endereço: SQS } 116 \text { Bloco J Apt } 603 \\
\text { Telefone: +55 (61) 3037-8018 Fax: +55 (61) 3963-9122 } \\
\text { E-mail: kleberferriche@ibest.com.br }\end{array}$ \\
\hline 29 & $\begin{array}{l}\text { IBEP } \\
\text { Endereço: SEPN Qd. 511 Bloco B no } 57 \text { - 5을 Andar Ed. Bittar III } \\
\text { Telefone: +55 (61) 3347-4748 Fax: +55 (61) 3349-8393 } \\
\text { E-mail: petrônio@ibep.com.br }\end{array}$ \\
\hline 30 & $\begin{array}{l}\text { INSTITUTO CENTRO CAPE } \\
\text { Endereço: SCN Qd. 05 BI A Salas } 211 / 213 \text { - Torre sul - Ed Brasília Shopping } \\
\text { Telefone: +55 (61) 3328-0621 Fax: +55 (61) 3328-8393 } \\
\text { E-mail: admfinanc.bsb@centrocape.org.br }\end{array}$ \\
\hline 31 & $\begin{array}{l}\text { IDEAL EVENTOS } \\
\text { Endereço: SHIN QI 4, conjunto } 10 \text { casa } 21 \text { - Lago Norte } \\
\text { Telefone: +55 (61) 3468-6656 Fax: +55 (61) 3468-6656 } \\
\text { E-mail: ideal@idealeventos.com,br } \\
\text { Horário de Funcionamento: } 9 \mathrm{~h} \text { às } 18 \mathrm{~h}\end{array}$ \\
\hline 32 & $\begin{array}{l}\text { IMAGENS } \\
\text { Endereço: SRTVN Qd. } 701 \text { Conj. C N. } 124 \text { Sala } 803 \text { Ala B Centro Empresarial } \\
\text { Norte, Brasília-DF CEP: } 70.710-200 . \\
\text { Telefone: (61) 3403-0500 Fax: (61) 3403-0500 } \\
\text { e-mail: atendimento@imagenspromocoes.com.br }\end{array}$ \\
\hline 33 & $\begin{array}{l}\text { INTERMEDIUM } \\
\text { Endereço: Setor de Rádio e TV Sul qd 701, Ed. Palácio do Rádio II sala } 113 \\
\text { Telefone: }+55 \text { (61) 3224-9077 Fax: }+55 \text { (61) 3226-2159 } \\
\text { E-mail: intermedium@uol.com.br } \\
\text { Horário de Funcionamento: } 9 \mathrm{~h} \text { às } 19 \mathrm{~h}\end{array}$ \\
\hline 34 & $\begin{array}{l}\text { IPA } \\
\text { Endereço: SHIS QI } 26 \text { Bloco E sala } 203 \\
\text { Telefone: }+55 \text { (61) 3248-8100 Fax: +55 (61) 3248-8124 }\end{array}$ \\
\hline 35 & $\begin{array}{l}\text { L \& M PRODUÇŌES E EVENTOS } \\
\text { Endereço: CLSW } 301 \text { Bloco C Loja } 46 \text {-Subsolo - Ed Dakota Shopping } \\
\text { Telefone: +55 (61) 3344-1669 } \\
\text { E-mail: atendimento@improdutora.com.br }\end{array}$ \\
\hline 36 & $\begin{array}{l}\text { MARCIA LIMA PRODUÇÕES E EVENTOS } \\
\text { Endereço: SHC/SUL quadra 207, bloco A, loja } 25 \text { - Asa Sul } \\
\text { Telefone:+55 (61)3443-5557 Fax: +55 (61) 3443-5557 } \\
\text { E-mail: márcia.eventos.@uol.com.br } \\
\text { Horário de Funcionamento: } 9 \mathrm{~h} \text { às } 19 \mathrm{~h}\end{array}$ \\
\hline 37 & $\begin{array}{l}\text { MATERIA PRIMA } \\
\text { Endereço: SCLN } 403 \text { Bloco B Sala } 102 \\
\text { Telefone: +55 (61) 3328-5449 } \\
\text { E-mail: eventos@materiaprima.com.br }\end{array}$ \\
\hline 38 & $\begin{array}{l}\text { MARC SYSTEMS } \\
\text { Endereço: CSG } 10 \text { lote } 15 \\
\text { Telefone: }+55 \text { (61) 3356-1138 Fax: +55 (61) 3356-1138 } \\
\text { E-mail: marcsystems@br.inter.net }\end{array}$ \\
\hline 39 & $\begin{array}{l}\text { MERCADO CULTURAL } \\
\text { Endereço: SD/Sul Bloco A no44 sala } 414 \text { Edifício Conic Setor de Diversões Sul } \\
\text { Telefone: +55 (61) 3321-5209 Fax: +55 (61) 3321-1764 } \\
\text { E-mail: mercadocultural@terra.com.br }\end{array}$ \\
\hline
\end{tabular}




\begin{tabular}{|c|c|}
\hline 40 & $\begin{array}{l}\text { MG BRASIL } \\
\text { Endereço: SEPS 705/905 Conj "B" sala 304/306 } \\
\text { Telefone: +55 (61) 3244-2366 Fax: +55 (61) 3244-9261 } \\
\text { E-mail: mgbrasileventos@uol.com.br }\end{array}$ \\
\hline 41 & $\begin{array}{l}\text { MONDAY MONDAY PROMOÇÕES E EVENTOS } \\
\text { Endereço: SCN Qd. 05 Bloco A no } 50 \text { salas 926/928 } \\
\text { Telefone: +55 (61) 3327-1179 Fax: +55 (61) 3328-1502 } \\
\text { E-mail: micarecandanga@micarecandanga.com.br }\end{array}$ \\
\hline 42 & $\begin{array}{l}\text { NEO EVENTOS } \\
\text { Endereço: SAI/SUL QD 05 C LT "S 17/18 sala } 212 \\
\text { Telefone: +55 (61) 3234-0515 } \\
\text { E-mail: liliane@neoeventosbrasilia }\end{array}$ \\
\hline 43 & $\begin{array}{l}\text { NEW VISION } \\
\text { Endereço: Setor Hoteleiro Sul, qd 1, b A, lote } 5 \text {, Galeria do Hotel Nacional } \\
\text { Telefone: }+55 \text { (61) } 3322-0548 \text { Fax: }+55(61) 3322-2349 \\
\text { E-mail: newvision@terra.com.br } \\
\text { Horário de Funcionamento: } 8 \mathrm{~h} \text { às } 12 \mathrm{~h} \text { e das } 14 \mathrm{~h} \text { às } 18 \mathrm{~h}\end{array}$ \\
\hline 44 & $\begin{array}{l}\text { PONCE DE LEON REPRESENTAÇÕES E EVENTOS } \\
\text { Endereço: SCS Qd. 06 Bloco A no } 81 \text { sala } 621 \\
\text { Telefone: +55 (61) 3224-2950 Fax: +55(61) 3224-2017 } \\
\text { E-mail: ileon@unimet.com.br }\end{array}$ \\
\hline 45 & $\begin{array}{l}\text { PIPOCA PRODUÇÖES } \\
\text { Endereço: Setor Hoteleiro Sul Quadra } 06 \text { Conjunto A } \\
\text { Ed.Brasil XXI }- \text { Asa Sul } \\
\text { Telefone: }+55(61) 3202.4011 \text { Fax: }+55(61) 3202.4010 \\
\text { E-mail: } \text { atendimento@pipocaproducoes.com.br } \\
\text { Site: www.pipocaproducoes.com.br }\end{array}$ \\
\hline 46 & $\begin{array}{l}\text { QUALITY PRODUÇÖES LTDA } \\
\text { Endereço: Chácara 118, Rua } 10 \text { lote } 21 \text { loja 01. Vicente Pires. } \\
\text { Telefone/fax: }+55 \text { (61) 3397-4747 } \\
\text { E-mail: saque@qualityproducoes.com.br } \\
\text { Horário de Funcionamento: } 8 \mathrm{~h} \text { às } 18 \mathrm{~h}\end{array}$ \\
\hline 47 & $\begin{array}{l}\text { RENOVAR EVENTOS E PROMOÇÖES LTDA. } \\
\text { Endereço: CLN } 309 \text { BI. D Sala 102 - Asa Norte } \\
\text { Telefone: (61) 3340-0009 / (61) 3347-7390 Fax (61) 340-0009 } \\
\text { E-mail: renovar@renovareventos.com.br } \\
\text { Horário de funcionamento: 08h30min as 18h00min }\end{array}$ \\
\hline 48 & $\begin{array}{l}\text { ROME FEIRAS E PROMOÇÕES LTDA } \\
\text { Endereço: SHS Qd. } 6 \text { Conj. A Sala } 1513 \text { - Ed. Business Center Park } \\
\text { Telefone: +55 (61) 225-0161 Fax: +55 (61) 33039-9284 } \\
\text { E-mail: rome@rome.com.br }\end{array}$ \\
\hline 49 & $\begin{array}{l}\text { RORIZ COMERCIO E SERVIÇOS LTDA } \\
\text { Endereço: SCSUL Qd. 07 Bloco A no100 sala } 1112 \\
\text { Telefone:+55 (61) 3278-3050 Fax: +55 (61) 3281-4612 } \\
\text { E-mail: leonardo@roriznet }\end{array}$ \\
\hline 50 & $\begin{array}{l}\text { RP LABOR } \\
\text { Endereço: SRTVS Qd. } 701 \text { Conj L Bloco } 2 \text { Lojas } 106 \text { e } 112 \text { - Térreo } \\
\text { Telefone: +55(61) 3225-0207 Fax: +55 (61) 3225-4702 } \\
\text { E-mail: tais@grupolabor.com }\end{array}$ \\
\hline 51 & $\begin{array}{l}\text { SA EVENTOS E SOLUÇŌES } \\
\text { Endereço: SIA Trecho 3/4 Lote } 625 \text { Bloco C Sala } 104 \\
\text { Telefone:+55 (61) Fax: +55 (61)3202-2229 / 8402-4081 } \\
\text { E-mail: executivo@ saeventos.com.br } \\
\text { Site: www.saeventos.com.br }\end{array}$ \\
\hline 52 & $\begin{array}{l}\text { S"LYS EVENTOS } \\
\text { Endereço: SEP/sul EQ 705/905 Bloco C no } 25 \text { sala } 127 \\
\text { Telefone: +55 (61) 3242-9897 } \\
\text { E-mail: lyseventos@bol.com.br }\end{array}$ \\
\hline 53 & $\begin{array}{l}\text { SET FILMAGEM } \\
\text { Endereço: SIG Qd. } 08 \text { n } 2268 \text { Parte B }\end{array}$ \\
\hline
\end{tabular}




\begin{tabular}{l|l}
\hline & Telefone: +55 (61) 3343-0175 \\
& E-mail: setfilmagem@uol.com.br \\
\hline $\mathbf{5 4}$ & SOIC MARKETING PROMOCIONAL \\
& Endereço: SRTVN Qd. 701 Conjunto C no124 Ala A Salas 123, 125 e 127 \\
& Telefone: +55 (61) 3327-1517 \\
& E-mail: soic@ soic.com.br \\
\hline $\mathbf{5 5}$ & TERRAVISTA EVENTOS \\
& Endereço: SAl Sul Trecho 04 Lote 370 Bloco A Sala 204 \\
& Telefone: +55 (61) 3328-7533 Fax: +55 (61) 3326-8656 \\
& E-mail: comercial@terravistaeventos.com.br \\
\hline $\mathbf{5 6}$ & TRADU-SOM \\
& Endereço: SCLRES Bloco D-20 Sala 336 \\
& Telefone: +55 (61) 3233-9266 \\
& E-mail: tradusom@tradusom.com.br \\
\hline $\mathbf{5 7}$ & TRISCOM - COMUNICAÇÃO E EVENTOS \\
& QMSW 04 Lote 04 Sl. 322 - Ed. Monte Olimpo \\
& Tel/Fax: 61. 3342-3417 \\
& E-mail: triscom@triscom.com.br \\
& Site: www.triscom.com.br \\
\hline $\mathbf{5 8}$ & VIVENCE EVENTOS DE NEGÓCIOS \\
& EndereçO: SIA/SUL Trecho 10 lote 10/05 Multifeira Box 181-setor B \\
& Telefone: +55 (61) 3343-3533 \\
& E-mail: vivence@pop.com.br \\
\hline
\end{tabular}

Fonte: Autora compilada com base em informaçoes da ABEOC 


\section{7- VIABILIDADE TÉCNICO-ADMINISTRATIVA}

Nesta etapa é necessário que haja todo o dimensionamento técnico do projeto. Dimensionar tecnicamente um projeto significa identificar e quantificar todos os recursos necessários à implantação e operação do novo negócio. Deve-se considerar a partir das características técnicas do produto/serviço e do processo os seguintes recursos:

- Materiais tecnológicos;

- Materiais humanos;

- Investimentos;

- Custeio operacional.

Deve ser respondido, pelos dados levantados e pela análise, se as tecnologias de produto e de processo estão disponíveis, isto é, existem no mercado, são acessíveis economicamente falando e são viáveis tecnicamente, levando em conta a escala e mão-de-obra.

\section{1- Produto / Serviço}

A empresa oferecerá aos seus consumidores um mix de serviços e produtos bem variado e completo, que atenderá a demanda pela sua diversidade e qualidade dos mesmos.

A escolha dos produtos e serviços que serão comercializados foi feita através de pesquisa de opinião e análise do mercado em questão. No quadro 3 , foram relacionados todos os produtos e serviços que serão comercializados na empresa.

Com capacidade para organizar eventos de pequeno, médio e grande porte, a LDP Eventos executa serviços para todas as fases do evento, e de acordo com a característica apresentada, de forma que o cliente possa solicitar os serviços dos quais necessita, ou comprar um pacote completo de serviços e produtos para o evento que deseja realizar. 
QUADRO 3: Mix de Produtos e Serviços Oferecidos

\begin{tabular}{|c|c|}
\hline \multicolumn{2}{|c|}{ Tipos de Eventos } \\
\hline Almoços & Feiras \\
\hline Aniversários & Formaturas \\
\hline Café da Manhã Corporativos & Fórum \\
\hline Campeonatos & Inaugurações \\
\hline Casamentos & Jantares \\
\hline Concursos & Lançamentos \\
\hline Conferências & Palestras \\
\hline Confraternizações & Promoções \\
\hline Congressos & Seminários \\
\hline Convenções & Shows \\
\hline Cursos & Simpósios \\
\hline Espetáculos & Treinamentos \\
\hline Eventos Esportivos & Workshops \\
\hline Exposições & Outros Eventos \\
\hline \multicolumn{2}{|c|}{ Serviços e Produtos } \\
\hline Alimentos e Bebidas & Locação de Espaços \\
\hline Animação & Logistica \\
\hline Assessoria de Imprensa & Manutenção e Limpeza \\
\hline Atendimento Médico & Material Gráfico \\
\hline Brindes personalizados & Montagem e Desmontagem de Stands \\
\hline Cerimonial & Música \\
\hline Comercialização de Stands & Produção do Material do Participante \\
\hline Confecção e Distribuição de Convites & R.S.V.P \\
\hline Decoração e Ambientalização & Recepcionistas Bilingue \\
\hline Divulgação & Segurança \\
\hline Equipamentos Audiovisuais & Software para Eventos \\
\hline Foto e Filmagem & Tradução Simultânea \\
\hline Gerenciamento de Inscrições & Transporte \\
\hline Hospedagem & Outros Serviços e produtos \\
\hline
\end{tabular}

\section{2- Mão-de-Obra}

A equipe será formada por profissionais qualificados e capacitados a oferecer todo o suporte necessário, permitindo que os clientes compartilhem os bons momentos junto a seus convidados com segurança e tranqüilidade. 
A empresa necessitará, para integrar seu quadro de recursos humanos, profissionais que sejam capacitados para desenvolver suas funções; este quadro será formado por 03 funcionários fixos: proprietária-gerente, promotora de eventos e secretária, e também um completo banco de dados de mão-de-obra free lancer, para prestar serviço nos eventos, ou seja, será terceirizada mao-de-obra especializada no segmento, de forma a evitar um gasto fixo mensal com funcionários que não são necessários durante $o$ ano todo, mas apenas durante a realização de um evento.

O quadro 4 mostra como será a folha de pagamento desses recursos humanos.

QUADRO 4: Quadro de Recursos Humanos

\begin{tabular}{|l|c|c|}
\hline \multicolumn{2}{|c|}{ FOLHA DE PAGAMENTOS E ENCARGOS } \\
\hline FUNÇÃO & $\begin{array}{c}\text { NÚMERO DE } \\
\text { FUNCIONÁRIOS / SALÁRIO }\end{array}$ & SALÁRIO ESTIMADO \\
\hline Gerente & $01 \times 3.200,00$ & $3.200,00$ \\
\hline Promotora de Eventos & $01 \times 1.500,00$ & $1.500,00$ \\
\hline Secretária & $01 \times 800,00$ & 800,00 \\
\hline Subtotal & & $\mathbf{5 . 5 0 0 , 0 0}$ \\
\hline Encargos Sociais - 35\% & & $1.925,00$ \\
\hline Vale Transporte & 3 & $\mathbf{7 . 6 1 7 , 0 0}$ \\
\hline \multicolumn{1}{|c|}{ TOTAL } & & \\
\hline
\end{tabular}

\subsection{1- Organograma}

O organograma da empresa é do tipo funcional e simplificado, portando haverá somente uma gerência para o setor administrativo e operacional; assim o organograma é composto pela gerência geral, seguido da promotora de eventos, secretária e também os free lancers que são as pessoas contratadas temporariamente para prestar serviço nos eventos.

O serviço de contador e/ou escritório contábil também será terceirizado, como mostra o organograma na figura 2 : 
FIGURA 2: Organograma

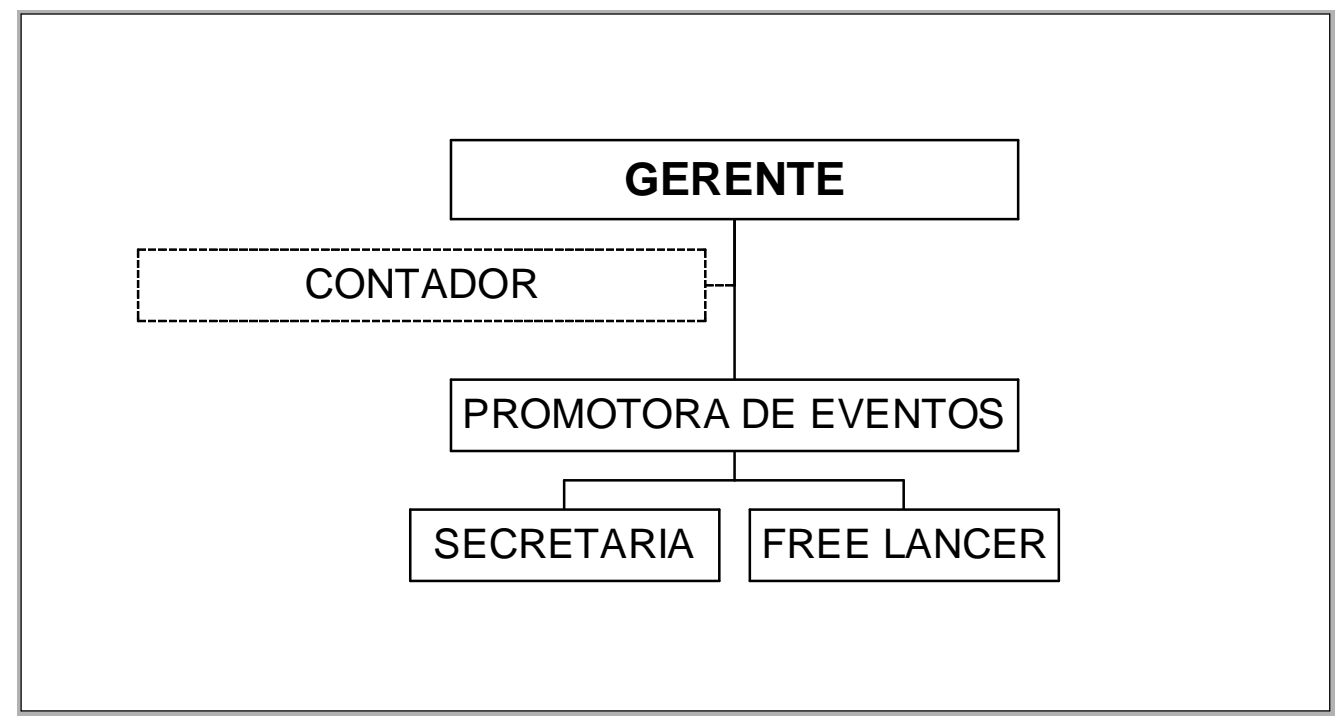

\section{3- Fornecedores}

O relacionamento com os fornecedores se dão em duas fases distintas: a primeira é o contato inicial, quando se conhece um fornecedor, seus produtos e serviços, e posteriormente, a manutenção do relacionamento necessário com um fornecedor habitual.

Deve-se fazer no mínimo três cotações com fornecedores diferentes, para cada produto ou serviço que a empresa for utilizar, principalmente se forem produtos ou serviços consumidos em grande quantidade.

Entende-se que o ramo de eventos exige extremo cuidado na contratação de um serviço ou compra de um produto, pois a falha em apenas um produto ou serviço pode pôr todo o evento a perder; por isso os fornecedores deverão ser rigorosamente selecionados e atender certos padrões de qualidade, haja vista que o está em jogo é o nome da LDP Eventos e não dos fornecedores em particular.

O pedido de produtos e a contratação de serviços será feita de acordo com as características do evento que estará sendo organizado pela LDP Eventos, ou seja, será feito um check-list e analisadas todas as necessidades para a perfeita realização desse evento e depois contratados todos os serviços de terceiros. 


\section{4- Recursos Imóveis}

O espaço físico de uma empresa tem sua importância relacionada com o produto, os serviços oferecidos e o mercado-alvo.

Para uma empresa como a LDP Eventos é muito importante que os seus clientes sejam recebidos com a mesma qualidade e excelência dos serviços e produtos que a empresa comercializa, principalmente no primeiro contato, no momento em que se tem a primeira impressão do que se está comprando.

Ocupando uma área de $40 \mathrm{~m}^{2}$, a LDP Eventos apresentará uma estrutura interna altamente informatizada e flexível, capaz de ajustar-se rapidamente para atender a cada tipo de evento a ser realizado.

O imóvel, onde a empresa se instalará, será alugado por um valor mensal de $R \$ 1.100,00$ (hum mil e cem reais) e um condomínio de $R \$ 380,00$ (trezentos e oitenta reais).

Esse é um dos fatores de custo que pode desequilibrar até a viabilidade do negócio caso não esteja bem dimensionado, uma vez que esta despesa compõe o quadro de despesas fixas, ou seja, independente do tamanho da receita, essa despesa deve ser paga.

\section{5- Recursos Móveis, Materiais, Equipamentos e Utensílios}

Para o funcionamento do escritorio da LDP Eventos, serão necessários alguns recursos móveis, materiais e equipamentos.

No quadro 5 , segue a descrição de todos os recursos materiais necessários, a quantidade e os respectivos valores.

Vale ressaltar que os itens relacionados são somente para compor o escritório da LDP Eventos; os equipamentos, recursos móveis e materiais para a realização do evento, ou seja, a parte operacional, serão locados ou adquiridos para cada evento em particular. 
QUADRO 5: Recursos Móveis, Materiais e Equipamentos

\begin{tabular}{|c|c|c|c|}
\hline QUANTIDADE & DESCRIÇÃO & $\begin{array}{c}\text { VALOR } \\
\text { UNITARIO }\end{array}$ & $\begin{array}{l}\text { VALOR } \\
\text { TOTAL }\end{array}$ \\
\hline 1 & aparelho de fax & 450,00 & 450,00 \\
\hline 3 & aparelho telefônico & 45,00 & 135,00 \\
\hline 1 & armário 4 portas & 800,00 & 800,00 \\
\hline 1 & armário arquivo & 380,00 & 380,00 \\
\hline 1 & Bandeija para Café & 55,00 & 55,00 \\
\hline 6 & cadeira estofada & 89,00 & 534,00 \\
\hline 3 & cadeira para escritório & 50,00 & 150,00 \\
\hline 1 & cafeteira elétrica & 160,00 & 160,00 \\
\hline 3 & calculadora comum & 15,00 & 45,00 \\
\hline 3 & Computador & $2.300,00$ & $6.900,00$ \\
\hline 1 & dispenser para papel toalha & 29,00 & 29,00 \\
\hline 1 & dispenser para sabão líquido & 15,00 & 15,00 \\
\hline 1 & filtro elétrico & 300,00 & 300,00 \\
\hline 3 & grampeador & 18,00 & 54,00 \\
\hline 1 & impressora Multifuncional & 550,00 & 550,00 \\
\hline 1 & jogo de sofá & 620,00 & 620,00 \\
\hline 1 & jogo de xícara de café & 38,00 & 38,00 \\
\hline 3 & Lixeira para escritório & 22,00 & 66,00 \\
\hline 3 & Mesa para computador & 380,00 & 1140,00 \\
\hline 3 & organizador de mesa & 25,00 & 75,00 \\
\hline 1 & revisteiro & 58,00 & 58,00 \\
\hline 1 & Tapete social & 200,00 & 200,00 \\
\hline 2 & uniforme para secretaria & 120,00 & 240,00 \\
\hline & TOTAL & & $R \$ 12.994,0 C$ \\
\hline
\end{tabular}




\section{8- VIABILIDADE ECONÔMICA-FINANCEIRA}

Após a análise mercadológica onde ocorrem as definições de volume e preço e, portanto, da "receita operacional", bem como o dimensionamento e análise técnica onde estima-se os investimentos e gastos operacionais, devem ser gerados os fluxos econômicos projetados do negócio.

A partir desses elementos pode-se proceder as análises econômicas e financeiras, tais como:

Prazo de retorno do capital;

Ponto de equilíbrio;

Essas análises são indispensáveis para a avaliação final da viabilidade do empreendimento.

Tão importante quanto as análises mercadológicas e técnica, a análise de viabilidade econômico-financeira da empresa busca conseguir todos os recursos aos menores custos possíveis, com o melhor retorno do capital aplicado no negócio.

O empreendedor deve iniciar essa análise visando, principalmente, a partir de que volume de atividade econômica a empresa se torna viável e lucrativa.

Para a LDP Eventos, no aspecto econômico-financeiro, o maior desafio será buscar continuamente uma conciliação entre o risco e o retorno para a empresa, ou seja, obter lucro após pagar todas as suas contas e dívidas dentro dos vencimentos, e equilibrar receita/despesa, bem como a sua sustentabilidade.

Todos os valores apresentados nesses estudos são em reais $(R \$)$.

\section{1- Fluxo e Demonstração dos Resultados}

O fluxo financeiro do projeto em estudo formou-se por diversos quadros de dados e valores, que possibilitou a análise de viabilidade da LDP Eventos. 
Quadro 6: Investimento Inicial e Depreciações

\begin{tabular}{l|c|c|c|c}
\hline \multicolumn{1}{c|}{ ESPECIFICAÇÃO } & QUANTIDADE & $\begin{array}{c}\text { VALOR } \\
\text { TOTAL R\$ }\end{array}$ & VIDA ÚTIL (ANOS) & VALOR R\$ \\
\hline Equipamentos/ maquinários & diversos & $9.170,00$ & 5 & 155,22 \\
\hline Móveis & diversos & $3.824,00$ & 10 & 31,74 \\
\hline Estoque Inicial & 1 & 560,00 & - & - \\
\hline Abertura de Firma & 1 & $2.082,65$ & - & - \\
\hline Criação Logo/material gráfico & 1 & $2.600,00$ & - & - \\
\hline Reformas e Decoração & $40 \mathrm{~m}^{2}$ & $10.360,00$ & - & $\mathbf{1 8 6 , 9 6}$ \\
\hline \multicolumn{1}{c}{ TOTAL } & - & $\mathbf{2 8 . 5 9 6 , 6 5}$ & TOTAL & - \\
\hline
\end{tabular}

O quadro 6 demonstra todos os investimentos iniciais e suas respectivas depreciações, os valores para equipamentos/maquinários e móveis, quando somados, encontra-se o mesmo valor demonstrado no quadro 5 , que nesta tabela foram agrupados por classe de recursos.

O estoque inicial é todo o custo de material necessário para a abertura do escritório da LDP Eventos.

A abertura da firma, implica em toda documentação necessária, despesas com cartório, fotocópias, autenticações e taxas.

A criação da logomarca e material gráfico, é o valor que será pago à agência de comunicação que criará a logo e todo o material de papelaria da LDP Eventos, e as despesas com reformas e decoração são valores orçados para reformar, decorar e preparar o escritório para iniciar suas atividades.

Os investimentos iniciais da LDP Eventos são da ordem de $\mathrm{R} \$$ 28.596,65 e a depreciação dos recursos móveis e materiais, é de $R \$ 186,96$. 
QUADRO 7: Despesas Fixas

\begin{tabular}{l|c}
\hline \multicolumn{1}{c|}{ DISCRIMINAÇÃO } & VALOR R\$ \\
\hline Aluguel do Imóvel & $1.100,00$ \\
\hline Condomínio do Imóvel & 380,00 \\
\hline Salários e Encargos & $7.617,00$ \\
\hline Depreciações & 186,96 \\
\hline Energia & 120,00 \\
\hline Telefone & 650,00 \\
\hline Honorário Contábeis & 350,00 \\
\hline Manutenção & 100,00 \\
\hline Materiais de Limpeza & 50,00 \\
\hline Materiais de Escritório & 198,00 \\
\hline Outras Despesas & 200,00 \\
\hline
\end{tabular}

As despesas fixas, apresentadas no quadro 7 , compreendem as despesas que mensalmente devem ser pagas, independentemente da receita obtida, dentre as várias despesas, os valores para salário e encargos são explicados no quadro 4 , e as depreciações no quadro 6.

QUADRO 8: Custos Variáveis / Despesas de Comercialização

\begin{tabular}{l|c}
\hline Custos Variáveis & $30.6 \%$ \\
\hline ISS & $5,00 \%$ \\
\hline COFINS & $3,00 \%$ \\
\hline CONTRIBUÍÇÃO SOCIAL & $0,96 \%$ \\
\hline PIS & $0,65 \%$ \\
\hline IRPJ & $4,80 \%$ \\
\hline & TOTAL \\
\hline
\end{tabular}


No quadro 8, são definidas as percentagens referentes aos custos variáveis e as despesas de comercialização.

Os custos variáveis resultam em $45.01 \%$ da receita, e foram definidos a partir dos custos de transporte e de comunicação gastos na prestaçao dos serviços contratados.

QUADRO 9: Receita Operacional Mensal

\begin{tabular}{l|c}
\hline \multicolumn{1}{c|}{ ESPECIFICAÇÃO } & VALOR R\$ \\
\hline Total da Venda de Serviços e Produtos & $29.240,00$ \\
\hline
\end{tabular}

O quadro 9 apresenta o valor da receita operacional mensal, que foi definida no quadro 2.

QUADRO 10: Demonstração de Resultado

\begin{tabular}{l|l|c|c}
\hline ITEM & \multicolumn{1}{|c|}{ ESPECIFICAÇÃO } & VALOR R\$ & $\%$ \\
\hline 1 & Receita Operacional & $\mathbf{2 9 . 2 4 0 , 0 0}$ & 100 \\
\hline 2 & Despesa de Comercialização & $\mathbf{1 3 . 1 6 0 , 9 2}$ & 45.01 \\
\hline 3 & Despesas Fixas & $\mathbf{1 0 . 9 5 1 , 9 6}$ & 37.45 \\
\hline 4 & Custo Total & $\mathbf{2 4 . 1 1 2 , 8 8}$ & 82.46 \\
\hline 5 & Lucro Líquido & $\mathbf{5 . 1 2 7 , 1 2}$ & 17.54 \\
\hline 6 & Margem Contribuição Total & $\mathbf{1 6 . 0 7 9 , 0 8}$ & 54.99 \\
\hline 7 & Ponto de Equilíbrio em Receita & $\mathbf{1 9 . 5 6 0 . 5 6}$ & 66.89 \\
\hline
\end{tabular}

A demonstração de resultado típica, apresentada no quadro 10, com as totalizações de receitas, custos variáveis, custo de despesas fixas e lucro líquido, permite a análise de indicadores de resultados para aferir a viabilidade econômicofinanceira do projeto. 
QUADRO 11: Investimento Inicial

\begin{tabular}{l|l|c}
\hline ITEM & \multicolumn{1}{|c|}{ ESPECIFICAÇÃO } & VALORES R\$ \\
\hline 1 & Investimento Fixo & $\mathbf{2 8 . 5 9 6 , 6 5}$ \\
\hline 2 & Capital de Giro * & $\mathbf{4 . 0 0 0 , 0 0}$ \\
\hline 2.2 & Despesas Fixas & $\mathbf{1 0 . 9 5 1 , 9 6}$ \\
\hline 3 & SUB TOTAL & $\mathbf{4 3 . 5 4 8 , 6 1}$ \\
\hline 4 & Imprevistos ( 5\% item 2) & $\mathbf{2 0 0 , 0 0}$ \\
\hline 5 & TOTAL (3+4) & $\mathbf{4 3 . 7 4 8 . 6 1}$ \\
\hline
\end{tabular}

* Considerando que a expectativa é que a demanda e os resultados do primeiro exercício estarão muito próximos dos projetados e que os estoques iniciais já estão incluidos no investimento fixo, considerou-se para capital de giro, como medida de segurança, um fundo de $R \$ 4.000,00$, que representa, aproximadamente, $37 \%$ das despesas fixas de um exercício.

QUADRO 12: Valores e Índices para Análise

\begin{tabular}{c|c|c}
\hline $\begin{array}{c}\text { PONTO DE EQUILIBRIO } \\
\text { R\$ }\end{array}$ & $\begin{array}{c}\text { REMUNERAÇÃO DO } \\
\text { CAPITAL \% }\end{array}$ & $\begin{array}{c}\text { PRAZO DE RETORNO DO } \\
\text { INVESTIMENTO }\end{array}$ \\
\hline $\mathrm{PE}=\underline{\text { Custo Fixo }} \times 100$ & $\underline{\text { Lucro Líquido }} \times 100$ & $\frac{\text { Capital Investido }}{\text { Lucro Liquido }}$ \\
$\%$ Margem Contribuição & Capital Investido & Prazo de Retorno $=\mathbf{8 . 5}$ meses \\
\hline $\mathrm{PE}=\mathrm{R} \$ \mathbf{1 9 . 5 6 0 , 5 6}$ & $\mathrm{RC}=\mathbf{1 1 , 7 1 \%}$ & \\
\hline
\end{tabular}

A partir de todos os dados obtidos, construi-se o quadro 12, onde resultados como o ponto de equilibrio, a remuneraçao do capital e o prazo de retorno do investimento foram concluídos e utilizados para uma análise detalhada no parecer do estudo das viabilidades. 


\section{9- CONSIDERAÇÕES FINAIS}

Considerando que o objetivo deste trabalho foi fazer um estudo de vialibidade de um novo empreendimento no setor de eventos na cidade de Brasília, nos planos mercadológico, técnico-administrativo e econômico-financeiro, realizouse este Plano de Negócios, que teve como parte integrante uma pesquisa de mercado e um estudo detalhado do cenário atual do segmento em questão.

Assim, após a organizaçao e análise de todos os dados do presente trabalho, concluiu-se que a LDP Eventos mostra-se um empreendimento viável e sua execução é recomendável.

Após a realização de pesquisa de campo, para avaliar a demanda de mercado e de toda tabulação e análise dos dados, pode-se concluir por uma boa aceitação da empresa no mercado. A pesquisa respondeu a todos os objetivos anteriormente determinados, indicando um nível de receita e perfil de consumo que acabaram por indicar a viabilização do negócio e orientar os principais aspectos que a presente empresa deverá apresentar aos seus consumidores.

Também obteve-se resultados satisfatórios quanto a viabilidade técnica-administrativa, pois os estudos realizados permitiram observar que será possível implementar, com custos compatíveis, todos os recursos de infra-estrutura, quadro de recursos humanos e demais recursos necessários para o funcionamento do setor técnico-administrativo.

Do ponto de vista econômico-financeiro, pode-se afirmar que o empreendimento é viável. Considerando-se uma receita operacional mensal prevista de $R \$ 29.240,00$, será obtido um lucro líquido mensal da ordem de $R \$ 5.127,12$.

Outro indicador de viabilidade é o ponto de equilíbrio da ordem de $R \$ 19.560,56$, ou seja, com as receitas previstas em $R \$ 29.240,00$, o empreendimento possui uma margem de segurança operacional de aproximadamente $33.5 \%$.

Quanto a remuneração do capital aplicado, os níveis de operação previstos resultarão num retorno de $11,71 \%$ ao mês, e um prazo de retorno do investimento de apenas 8,5 meses, indicadores que podem ser considerados excelentes, diante de outras alternativas disponíveis para investimentos. 
Assim, após a organizaçao e análise de todos os dados do presente trabalho, conclui-se que a LDP Eventos mostra-se um empreendimento viável e sua execução é recomendável.

No entanto para a real execução deste empreendimento aconselhase que seja realizada uma nova pesquisa que obtenha informações suficientes para determinar o segmento e definir o nicho em que a empresa pretende atuar.

Referente aos estudos realizados sobre empreendedorismo, vale a pena ressaltar que é dentro de um mundo moderno e cada vez mais sem fronteiras, que surgem as oportunidades, e cabe aos empreendedores, ou futuros empreendedores, transformá-las em negócios de sucesso. Porém, para que este negócio se concretize com êxito, é essencial que ele seja executado a partir de um Plano de Negócios, o qual é composto por etapas e processos que devem ser seguidos passo a passo.

É através de um Plano de Negócios que se comprovam as viabilidades mercadológica, técnica-administrativa e econômico-financeira, as quais responderão se a empresa tem espaço no mercado, se tem viabilidade financeira, apresentando um bom retorno no prazo estimado, e se tem viabilidade técnicaadministrativa, que dependerá também de outros fatores, como a oferta de mão-deobra que será utilizada.

$\mathrm{Na}$ elaboração deste Plano de Negócios, pode-se entender a importância que cada uma de suas fases representa para o sucesso do projeto e a necessária articulação entre elas. É fundamental que todas as análises sejam feitas com realismo, maturidade e autenticidade, representando assim maior certeza de viabilidade e êxito no negócio.

No Brasil, apesar do grande acúmulo de experiências bem sucedidas, durante muitos anos não se deu o valor necessário para a organização e o planejamento das empresas de modo que pudessem se desenvolver num ambiente de modernização e aperfeiçoamento permanentes. Sempre houve muito improviso, imediatismo, o chamado "jeitinho brasileiro", a visão pequena de desenvolvimento e a falta de incentivo para bons negócios e responsabilidade social dos empreendedores. 
Felizmente, o país vem mudando, a sociedade está mais exigente, os setores público e privado estão passando por muitas transformações e particularmente o segmento em estudo está sofrendo constantes mudanças, para atender as reais demandas do mercado e da sociedade.

Os eventos são, incontestavelmente, um dos maiores e melhores meios de desenvolvimento nacional, do fomento da economia, da geração de empregos, juntamente com o desenvolvimento de toda a infra-estrutura local; assim o turismo de eventos tem apresentado um crescimento acelerado se comparado às outras modalidades de turismo, e principalmente na capital do país. Brasilia está preparada para receber todos os tipos de eventos, e a cada dia mais ações estão sendo feitas para que este mercado cresça. A cidade já é considerada a Capital Brasileira do Turismo de Eventos.

Dentro desse cenário, existe hoje em Brasilia uma série de oportunidades para serem transformadas em negócios, e o empreendedor que souber aproveitá-las, certamente obterá sucesso e trará muitos benefícios a todos os envolvidos.

A oportunidade desta reflexão e elaboração de um Plano de Negócios que pretende ser desenvolvido, contribuiu para qualificar e agregar novos conhecimentos à formação obtida no curso e apontar os desafios ao longo da vida profissional. 


\section{0- REFERÊNCIAS BIBLIOGRÁFICAS}

AZEVEDO, João Humberto de. Como abrir seu prórpio negócio. Brasília: Ed. Sebrae, 1998.

BERNHOEFT. R. Empresa Familiar: sucessão profissionalizada ou sobrevivência comprometida. São Paulo: Nobel, 1996.

BRITO. Janaina. Estratégias para Eventos: uma otica do marketing e do turismo. Janaian Brito, Nena Fontes. - Sao Paulo: Aleph, 2002.

CASTELLI. Geraldo. Excelência em Hotelaria: uma abordagem prática. Rio de Janeiro: Ed Quality mark, 1994.

CHURCHILL, Gilbert. Marketing research: methodological foundations. 2a ed. The Dryden Press. 1998.

COHEN, D. Como se faz gente que faz? Revista Exame. Ago 2000.

DEGEN, R. J. O Empreendedor: fundamentos da iniciativa empresarial. São Paulo: McGraw-Hill, 1989.

DENCKER.A. F.M. Métodos e Técnicas de Pesquisa em Turismo. São Paulo: Futura,2000.

DOLABELA, Fernando. $O$ ensino do empreendedorismo: panorama brasileiro. Anais do Seminário: A universidade formando empreendedores. Brasília: CNI/IEL, 1999.

DOLABELA, Fernando. Uma revolução no ensino universitário de empreendedorismo no Brasil: a metodologia da oficina do empreendedor. Anais do Seminário: A universidade formando empreendedores. Brasília: CNI/IEL, 1999 a.

DRUCKER, P. F. Inovação e espírito empreendedor: prática e princípios. São Paulo: Pioneira, 1987.

DRUCKER, P. F. A nova era da Administração. 2 ed. São Paulo: Pioneira, 1986.

EMBRATUR/FIPE. Estudo, Caracterização e Dimensionamento do Mercado 
Doméstico de Turismo no Brasil. São Paulo, 2002.

FAULSTICH, Enilde Duarte de John. Como ler, entender e redigir um texto. 14. ed. Petrópolis: Vozes, 2001.

FBC\&VB. I Dimensionamento econômico da indústria de eventos no Brasil. São Paulo: 2001/2002.

FÜHRER, Maximilianus C. A. Resumo de Direito Comercial. 26 edição. São Paulo: Malheiros, 2001.

GIL, A. C. Como elaborar projetos de pesquisa. 1991. p. 45.

KOTLER, Philip. Administração de Marketing. São Paulo: Atlas, 1995.

KOTLER, Philip. Administração de Marketing: análise, planejamento, implementação e controle. 5ª edição. São Paulo: Atlas, 1998.

KOTLER, Philip. et al. Marketing Público- Como atrair investimentos, empresas e turismo para cidades, regiões, estados e países. Tradução: Eliane Kanner. São Paulo: Makron Books, 1994.

KOTLER, Philip; ARMSTRONG, Gary. Princípios de Marketing. 9a Ed. São Paulo: Prentice Hall, 2003.

LACOMBE, F. Dicionário de Administração. São Paulo: Saraiva, 2004.

LAS CASAS, Alexandre L. Marketing: conceitos, exercícios, casos. $4^{a}$ ed. São Paulo: Atlas, 1999.

LEMOS, Leandro de. Turismo: Que negócio é esse? São Paulo: Ed. Papirus, 2000.

MARCONDES, R. C. Criando empresas para o sucesso. Reynaldo Cavalheiro Marcondes, Cyro Bernardes. São Paulo: Atlas, 1997.

MATTAR, F. Pesquisa de Marketing. Ed. Atlas. 1996.

NICHOLS, Bárbara. Gerenciamento Profissional de Eventos. Tradução: Milena de Carvalho, Fortaleza: ABC Fortaleza, 1993. 
NORA, Rodrigo Muzulao. A importancia e a Historia dos Eventos. Sao Paulo, 2004.

OLIVEIRA, M. A. Valeu! Passos na trajetória de um empreendedor. São Paulo: Nobel, 1995.

OMT. Tourism Market Trends 2003 - World Overview \& Tourism Topics. Spain, OMT: 2003.

ROCHA, Ângela da. CHRISTENSEN, Carl. Marketing: Teoria e Prática no Prático. $2^{\underline{a}}$ ed. São Paulo: Atlas, 1999.

RISPOLI. Reginaldo. A força economica do turismo e o pujante mercado de eventos. Brasilia: Redgraf, 2003.

SALIM, C. S. et al. Construindo Planos de Negócios: todos os passos necessários para planejar e desenvolver negócios de sucesso. Rio de Janeiro: Campus, 2001.

SAMARA, Beatriz Santos. BARROS, José Carlos. Pesquisa de Marketing: conceitos e metodologia. 2 ${ }^{\mathrm{a}}$ edição. São Paulo: Makron Books, 1997.

SEBRAE. Como abrir sua empresa: manual prático. São Paulo: Sebrae-SP, 1996.

SEBRAE e ABIH. Aprender a empreender: módulos de estudo. São Paulo: 2005.

SEBRAE. Perfil Competitivo do Distrito Federal. Brasília: SENAI/DN SEBRAE/DF, 2002/2003.

SILVA, Nilza da Costa. Turismo de Eventos. Revista Turismo. 2003.

TONELLI, A. Elaboração de uma metodologia de capacitação aplicada ao estudo das características comportamentais dos empreendedores. Florianópolis, 1997. Dissertação (Mestrado em Engenharia de Produção) - PPGEP: UFSC, 1997.

ZANELLA. Luis Carlos. Manual de Organizaçao de Eventos: planejamento e operacionalizaçao. 2 ed. Sao Paulo: Atlas, 2004.

BRASIL. Associação Brasileira de Empresas de Eventos - ABEOC. Disponível em: <www.abeoc.org.br> acessado em 03/FEVEREIRO/2007. 
BRASIL. Associação de Marketing Promocional - AMPRO. Disponível em: $<$ www.ampro.com.br> acessado em 15/DEZEMBRO/2006.

BRASIL. Brasília e Região Convention \& Visitors Bureau. Disponível em: $<w w w . b r a s i l i a c o n v e n t i o n . c o m . b r>$ acessado em 18/DEZEMBRO/2006.

BRASIL. Codigo de Defesa do Consumidor / Ministério da Justiça. Brasilia -1998. Disponível em: <www.mj.goov.br> acessado em 15/FEVEREIRO/2007.

BRASIL. Departamento Nacional de Registro do Comercio - DNRC. Disponível em: <www.dnrc.gov.br> acessado em 22/JANEIRO/2007.

BRASIL. Instituto de Apoio às Pequenas e Médias Empresas e ao Investimento - IAPMEI. Disponível em: <www.iapmei.pt > acessado em 28/NOV/2006.

BRASIL. Jornal Meio \& Mensagem. Disponível em: <www.meioemensagem.com.br> acessado em 03/JANEIRO/2007.

BRASIL. Plano Nacional do Turismo: diretrizes, metas e programas 2003-2007 / Ministério do Turismo. Brasilia -2003. Disponível em: <www.mt.gov.br> acessado em 02/FEVEREIRO/2007.

BRASIL. SEBRAE Distrito Federal. Disponível em: <www.df.sebrae.com.br > acessado em 22/DEZEMBRO/2006.

BRASIL. SETUR - Secretaria de Turismo do Distrito Federal. Disponível em: $<$ www.brasiliaturismo.df.gov.br> acessado em 10/JANEIRO/2007.

BRASIL. Senado Federal. Disponível em: <www.senado.org.br/legislacao> acessado em 10/JANEIRO/2007. 


\section{1- APÊNDICES}

\section{APÊNDICE A - Mapa de Localização}

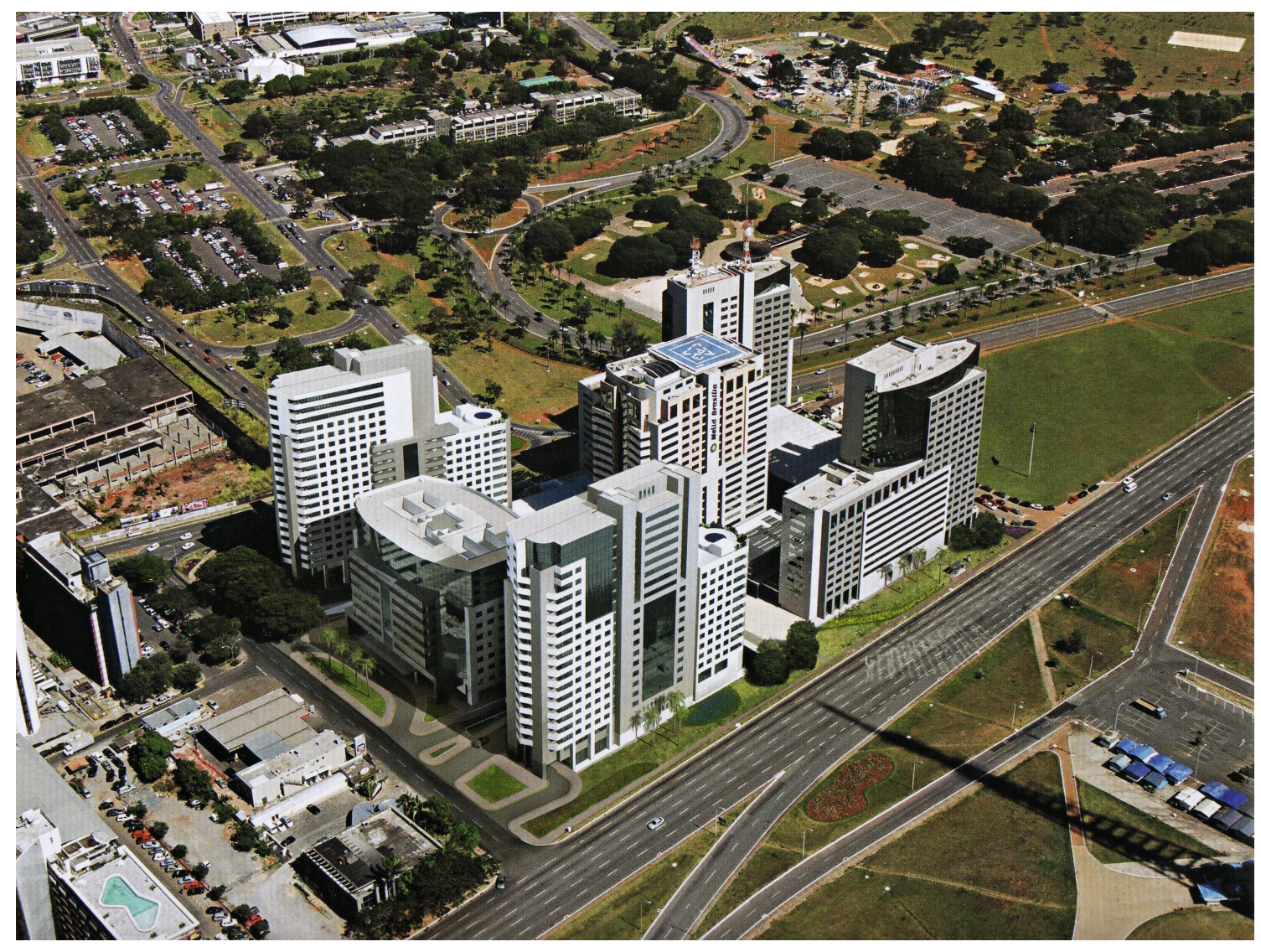


APÊNDICE B - Questionário de Pesquisa

\section{Questionário para Pesquisa de Mercado}

1) Qual o seu grau de interesse em contratar serviços de uma nova Agência de Eventos em Brasília?

( ) Totalmente interessado

( ) Parcialmente interessado

( ) Desinteressado

2) Com qual freqüência você contrata os serviços de uma Agência de Eventos?

( ) uma vez por mês

( ) uma vez por bimestre

( ) uma vez por semestre

( ) uma vez por ano

( ) Outros:

3) Quais os aspectos analisados ao optar por uma empresa organizadora de eventos?

(Colocar em ordem numérica crescente de 1 a 5 - use 1 para o mais importante)

( ) Credibilidade da empresa no mercado

( ) Preço

( ) Diversidade dos serviços oferecidos

( ) Qualificação da mão-de-obra utilizada na prestação dos serviços

( ) Qualidade do atendimento prestado

4) Qual o meio que você utiliza para encontrar uma Agência de Eventos?

( ) Internet

( ) Lista Telefônica

( ) Indicação de Amigos

( ) Material Publicitário (tv, outdoor, rádio, jornal e revista)

( ) Outros:

5) Para qual tipo de evento você contrataria uma Agência de Eventos?
( ) Treinamentos
( ) Formaturas
( ) Lançamentos ou Inaugurações
( ) Congressos ou Convenções
( ) Excursões
( ) Exposições ou Feiras
( ) Casamentos
( ) Concursos ou Campeonato
( ) Outros:

6) Quanto você costuma gastar ou gastaria ao contratar uma Agência Eventos?

( ) Até $\mathrm{R} \$ 2.000,00$

( ) De $R \$ 2,000,00$ até $R \$ 5,000,00$

( ) De $R \$ 5,000,00$ até $R \$ 10,000,00$

( ) Mais de $R \$ 10,000,00$ 